\title{
Journal of $\mathbf{E}_{\text {ntrepreneurship }} \mathbf{E}_{\text {ducation }}$
}

\author{
An official Journal of the \\ Academy of Entrepreneurship ${ }^{\circledR}$
}

\author{
Edited by \\ James W. Carland Jr. \\ Western Carolina University
}

The Academy of Entrepreneurship, Inc. is a non-profit corporation chartered under the laws of North Carolina and the United States. The Academy is an international association of scholars and practitioners whose purpose is to advance the knowledge, understanding, teaching and practice of entrepreneurship throughout the world. 
The Academy is not responsible for the content of the individual manuscripts. Authors provide the Academy with a publication permission agreement. Any omissions or errors are the sole responsibility of the individual authors. The Editorial Board is responsible for the selection of manuscripts for publication from among those submitted for consideration. The Editors and Publishers accept final manuscripts in digital form and make adjustments solely for the purposes of pagination and organization.

The Journal of Entrepreneurship Education is published by the Allied Academies, Inc., PO Box 2689, 145 Travis Road, Cullowhee, North Carolina 28723, USA, (828) 293-9151, FAX (828) 293-9407. Those interested in subscribing to the Journal, advertising in the Journal, or otherwise communicating with the Journal, should contact the Executive Director at info@alliedacademies.org.

Copyright 2006 by the Academy of Entrepreneurship ${ }^{\circledR}$, Inc., Cullowhee, NC, USA 


\section{JOURNAL OF ENTREPRENEURSHIP EDUCATION EDITORIAL BOARD MEMBERS}

Joe Aniello

Francis Marion University

Stephanie Bardwell

Christopher Newport University

Tom Box

Pittsburg State University

Thomas J. Boyle

Seton Hall University

Martin Bressler

Houston Baptist University

Kent Byus

Texas A\&M University - Corpus Christi

James W. Cagley

University of Tulsa

Jim and JoAnn Carland

Western Carolina University

Shawn M. Carraher

Cameron University

Sanjib Chowdhury

Eastern Michigan University

Larry R. Dale

Arkansas State University

Jo Ann M. Duffy

Sam Houston State University

Arthur K. Fischer

Pittsburg State University

R. Ganesan

Indian Institute of Technology Delhi

Robert D. Gulbro

Athens State University

Abdalla Hagen

Grambling State University

Michael Harris

Eastern Michigan University
Kirk Heriot

Western Kentucky University

Robert J. Hockin

TechArch, Inc.

Mark Hoelscher

Illinois State University

William T. Jackson

Dalton State College

Jayesh Kumar

Xavier Institute of Management

Kenneth J. Lacho

University of New Orleans

Bill Laing

Anderson University

Jonathan Lee

University of Windsor, Ontario

James R. Maxwell

Indiana State University

Kenneth K. Mitchell

Shaw University

Deependra Moitra

Lucent Technologies

Donatus Okhomina

Alabama State University

John A. Parnell

University of North Carolina at Pembroke

David P. Paul, III

Monmouth University

Terry Pearson

West Texas A\&M University

Steven E. Phelan

University of Nevada, Las Vegas

Keramat Poorsoltan

Frostburg State University 


\section{JOURNAL OF ENTREPRENEURSHIP EDUCATION EDITORIAL BOARD MEMBERS}

Sujata Satapathy

Indian Institute of Technology Delhi

Susan E. Saxton

Capella University

Gerald J. Segal

Florida Gulf Coast University

Linda Shonesy

Athens State University

William L. Smith

Emporia State University

Charles R. B. Stowe

Sam Houston State University
Rodney C. Vandeveer

Purdue University

V. P. Wani

National Institute of Technology

Paul G. Wilhelm

Cameron University

Denise Woodbury

Southern Utah University

Tom Wright,

University of Nevada, Reno 


\title{
JOURNAL OF ENTREPRENEURSHIP EDUCATION
}

\author{
CONTENTS
}

EDITORIAL BOARD MEMBERS $\ldots \ldots \ldots \ldots \ldots \ldots \ldots \ldots \ldots \ldots \ldots \ldots$ iii

LETTER FROM THE EDITOR $\ldots \ldots \ldots \ldots \ldots \ldots \ldots \ldots \ldots \ldots \ldots \ldots \ldots \ldots$ vii

ACADEMICALLY BASED ENTREPRENEURSHIP

CENTERS: AN EXPLORATION OF STRUCTURE

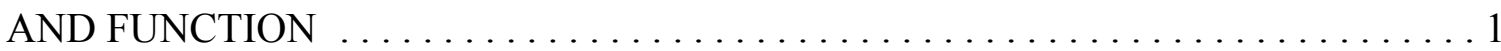

Michael R. Bowers, Rollins College

Cecilia McInnis Bowers, Rollins College

Gabriel Ivan, Rollins College

MANAGING BUSINESS PLANNING PROJECTS

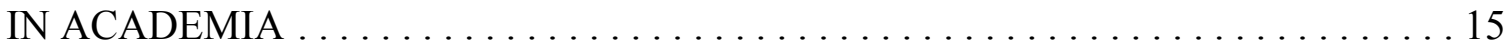

Colin Benjamin, Florida A \& M University

Booker Warren, Florida A \& M University

Janée Burkhalter, Florida A \& M University

INNOVATION IN ENTREPRENEURSHIP EDUCATION

Debra A. Arvanites, Villanova University

James M. Glasgow, Villanova University

James W. Klingler, Villanova University

Stephen A. Stumpf, Villanova University

A $21^{\text {st }}$ CENTURY MODEL OF ENTREPRENEURSHIP

EDUCATION: OVERCOMING TRADITIONAL

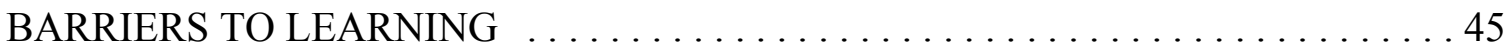

Brooke R. Envick, St. Mary's University

Prasad Padmanabhan, St. Mary's University 
MINDING OUR BUSINESS: A MODEL OF SERVICELEARNING IN ENTREPRENEURSHIP EDUCATION $\ldots \ldots \ldots \ldots \ldots \ldots \ldots \ldots$

Sigfredo A. Hernandez, Rider University

Cynthia M. Newman, Rider University

ECONOMIC KNOWLEDGE AND ENTREPRENEURIAL DISPOSITIONS IN ELEMENTARY STUDENTS:

THE ENTREPRENEURS IN KENTUCKY INITIATIVE . . . . . . . . . . . . . 77

Kimberly P. Code, Northern Kentucky University

EDUCATION AND TRAINING AS NON-PSYCHOLOGICAL CHARACTERISTICS THAT

INFLUENCE UNIVERSITY STUDENTS'

ENTREPRENEURIAL BEHAVIOUR

Juan Hernangomez Barahona, University of Valladolid

Natalia Martin Cruz, University of Valladolid

Ana Isabel Rodriguez Escudero, University of Valladolid

THE EFFECTS OF PERSONALITY AND EXPERIENCE

ON RESOURCE ACQUISITION PERFORMANCE:

AN EXPERIMENTAL STUDY

Steven E. Phelan, University of Nevada Las Vegas

G. Stoney Alder, University of Nevada Las Vegas

Journal of Entrepreneurship Education, Volume 9, 2006 


\section{LETTER FROM THE EDITOR}

Welcome to the Journal of Entrepreneurship Education, a publication dedicated to the study, research and dissemination of information pertinent to improvement of methodologies and effectiveness of entrepreneurship education. The editorial board considers three types of manuscripts. First is empirical research which examines the many facets of entrepreneurship and which expands the body of knowledge of entrepreneurship education. Second, case studies that have a demonstrated effectiveness and bring new perspectives to entrepreneurship education are considered. Third, manuscripts which document successful applied innovations in entrepreneurship education are solicited.

We are actively soliciting papers for the next volume of the Journal of Entrepreneurship Education. The process for submission of papers has been centralized through Allied Academies. All submissions are now electronic and go directly to Allied Academies. You may learn more about this process at www.alliedacademies.org. We are working to streamline our processes and we strive to have all papers reviewed and authors notified within three months of submission.

We are also seeking to grow our Editorial Review Board. If you are interested in reviewing submissions for the Journal, please submit a request by email to info@alliedacademies.org.

Thank you for your interest in The Journal of Entrepreneurship Education.

Jim Carland

Editor 


\section{ARTICLES}




\title{
ACADEMICALLY BASED ENTREPRENEURSHIP CENTERS: AN EXPLORATION OF STRUCTURE AND FUNCTION
}

\author{
Michael R. Bowers, Rollins College \\ Cecilia McInnis Bowers, Rollins College \\ Gabriel Ivan, Rollins College
}

\begin{abstract}
This paper describes the results of a national survey of directors of academically based entrepreneurship centers at colleges or universities. The results will be of interest to current and prospective center directors, faculty associated with such centers and administrators responsible for directing organizational resources to entrepreneurial activities.

We describe the general profile of current centers with regards to institutional resources (human and financial), activities in which the centers engage, levels of student involvement, composition of advisory boards, funding sources and means by which success is measured. We also describe the activities and structure of the typical center director's job. Attributes of centers are correlated with reported measures of success and levels of recognition. Content analysis of openended questions provides suggestions as to how excellence is achieved in centers and what challenges the future holds. The paper concludes with summary observations from the results and implications for centers in development or early in their operations.

The sampling frame was developed from a general Internet search, use of Entrepreneur magazine lists and the membership list of the National Consortium of Entrepreneurship Centers, and yielded a list of 120 centers. We received responses from 56 entrepreneurship centers for a response rate of $47 \%$.
\end{abstract}

\section{INTRODUCTION}

Entrepreneurial activities on college and university campuses have been increasing, at an increasing rate. These activities include developments in curricula and infrastructure, including centers (Katz, 2003). The rise in interest and activity of entrepreneurial education in higher education has sparked a concommitment interest on the part of academic researchers. The general state of entrepreneurship education was reported recently by Solomon, Duffy and Tarabishy (2002), with a new round of data gathering being conducted at the present time. Bechard and Gregoire (2005) published an article on the themes (or to use the author's term preoccupations) found in 
current research on entrepreneurship education. Despite this interest in entrepreneurial education at institutions of higher education, to our knowledge the role and functioning of academically based entrepreneurship centers has not been described. The goal of this paper is to describe the structure and functioning of a wide variety of entrepreneurship centers housed within institutions offering bachelor or graduate degrees in the United States. We explore center attributes correlated with selfreported measures of success and recognition. A qualitative appraisal of open-ended questions provides direction into the future for center directors. The paper concludes with summary observations from the results and implications for centers in development or early in their operations.

\section{METHODOLOGY}

The sampling frame was developed from a general Internet search, use of Entrepreneur magazine lists and the membership list of the National Consortium of Entrepreneurship Centers, and yielded a list of 120 centers. Center directors and their contact information were determined from the sampling frame. Three waves of electronic surveys were sent between June and September 2004. An accompanying cover letter explained the purpose of the research was attached and the identified contact person was asked to email the research team with new contact information if someone else was more appropriate to answer the survey. A final mailed survey was sent in September 2004. We received responses from 56 entrepreneurship centers with usable data, for a response rate of $47 \%$. The center directors participating in the study represent some of the largest and most well known universities in the world, some represent small public or private colleges with a regional or local focus.

\section{DESCRIPTIVE RESULTS FOR CENTER STRUCTURE}

Table 1 summarizes the "average" profile of centers in our study. The reported age of the centers in our survey ranged from a mature 26 years to less than one year, with the mean age of the centers being 9.5 years. An interesting observation is that almost thirty percent of the sample reported that their center is 5 or less year's old. This suggests that growth of new centers continues. Forty eight percent of our respondents are affiliated with a state supported institution, forty six

percent are found in private schools. Six percent categorized themselves as "other"; typically these centers were a combination of state/private/local government interests.

Average enrollment in the college or school of business for our respondents was 1666 (undergraduate and graduate students). The average number of full time faculty associated with the centers is six and the average number of part time faculty associated with the centers is four. On average, centers in our study report three full time support staff and two part timers. The average number of students in some sort of entrepreneurship course of study is 109 . The average number

Journal of Entrepreneurship Education, Volume 9, 2006 
of students involved with a student entrepreneurship organization (such as the Collegiate Entrepreneurs Organization, CEO) is 55.

\begin{tabular}{|l|c|}
\hline \multicolumn{2}{|c|}{ Table 1: A Profile of the Average Center } \\
\hline Age of the Center & 9.5 years \\
\hline Enrollment & 1666 (graduate and undergraduate) \\
\hline Full time Faculty & 6 \\
\hline Part time Faculty & 3 \\
\hline Full time Support & 2 \\
\hline Part time Support & 109 \\
\hline Students in courses & 55 \\
\hline Students in organizations & 3 \\
\hline
\end{tabular}

Concentrations in entrepreneurship are the most common type of curriculum specialization. Fifty five percent of the respondents reported their schools offering the concentration. A major in entrepreneurship was the second most common type of specialization, with $30 \%$ of the respondents reporting this as an option. A minor in entrepreneurship was the third most common specialization with only $18 \%$ of the respondents stating this was possible for the students. The percentages do not sum to $100 \%$ because some schools offer one, two or three of the entrepreneurship tracks simultaneously.

\begin{tabular}{|l|c|}
\hline \multicolumn{2}{|c|}{ Table 2: Entrepreneurship Curriculum Tracks } \\
\hline & Percentage of Centers \\
\hline Concentration & $55 \%$ \\
\hline Major & $30 \%$ \\
\hline Minor & $18 \%$ \\
\hline
\end{tabular}

Seventy five percent of the respondents reported having a Board of Advisors with 12 members on average sitting on the board. Table 3 illustrates the constituencies represented on the boards. Eight seven percent of the center directors report having members of the business community serve on their board. Faculty are the second most likely to serve. The "other" category is typically school administration (Deans and VP's of research). The average board meets twice a year. 


\begin{tabular}{|l|c|}
\hline \multicolumn{2}{|c|}{ Table 3: Constituencies Represented on the Board } \\
\hline & Percentage of Centers \\
\hline Business Community & $87 \%$ \\
\hline Faculty & $61 \%$ \\
\hline Government & $28 \%$ \\
\hline Students & $15 \%$ \\
\hline Other & $17 \%$ \\
\hline
\end{tabular}

A key finding from our survey is that almost $40 \%$ of the centers do not engage in strategic planning. This would suggest an opportunity to improve the business practices of entrepreneurship centers.

\section{DESCRIPTIVE RESULTS OF THE CENTER DIRECTORS JOB}

The most common direct report for center directors is to their dean (69\%). Twenty two percent of directors say they report to the department chair and nine percent report to the President/Provost/Chancellor (100\% total). The average percent of the director's time on the job is spent with center operations (43\%), with education/teaching being second (38\%). On average, only $19 \%$ of a center director's time is spent in fundraising. Center directors report their average control over the budget at 5.6 (on a seven point scale, with 7 defined as "absolute control"). Twenty five percent of the respondents said they had absolute control over the budget.

\begin{tabular}{|l|c|}
\hline \multicolumn{2}{|c|}{ Table 4: Center Director's Time } \\
\hline & (Mean percentages) \\
\hline Center Operations & $43 \%$ \\
\hline Education/Teaching & $38 \%$ \\
\hline Fundraising & $19 \%$ \\
\hline Total & $100 \%$ \\
\hline
\end{tabular}

Sixty eight percent of the center directors' background is not from academe, primarily from industry, with a minority reporting prior governmental/political work experience. However, eighty percent of the directors report they hold an academic rank in their institution. The most common rank is instructor/lecturer, with the second most common rank being an endowed chair. 


\section{DESCRIPTIVE RESULTS OF CENTER FUNDING}

Directors were asked what percentage of the funding for their center came from a variety of sources. The mean percentages are reported in Table 5. Endowments (including naming gifts and anchor gifts) are a major source of funding and represent stable source of income. Grants/contracts and private sponsorships represent almost thirty percent of the average center's funding and might be characterized as stable sources of revenue in the short term. Of surprise to the research team was the limited extent to which centers in our study relied upon attendance and membership fees for income.

\begin{tabular}{|l|c|}
\hline \multicolumn{2}{|c|}{ Table 5: Sources of Center Funding } \\
\hline & (Mean percentages) \\
\hline Endowments (including Anchor Gifts) & $40 \%$ \\
\hline Grants/Contracts & $15 \%$ \\
\hline Sponsorships & $13 \%$ \\
\hline State Funds & $8 \%$ \\
\hline Attendance Fees & $7 \%$ \\
\hline Membership Fees & $5 \%$ \\
\hline Other (tuition county university) & $12 \%$ \\
\hline Total & $100 \%$ \\
\hline
\end{tabular}

Directors were also asked where the growth in funding over the past two years had occurred. Table 6 describes the average percent growth in the variety of funding sources. Seeking endowments seems to be a common path to securing stable funding, as well as the pursuit of grants/contracts and sponsorships. Increases in state funds, membership and attendance fees do not seem as promising.

Growth in funding from the "Other" category shows double digit growth. An examination of the individual responses to this category indicates that some centers are receiving grants from private individuals but some centers are funding their growth by spending the corpus of their endowment. The long term success of such a strategy might be questioned.

Sixty percent of the centers in our study had endowed chairs in entrepreneurship, funded on average at $\$ 1,355,775$ with a maximum up to $\$ 5,000,000$. If a center had an endowed chair, $43 \%$ of were housed in the center, $43 \%$ were located in the hosting department (typically management), and 16\% were deemed School/College or University chairs. 


\begin{tabular}{|l|c|}
\hline \multicolumn{2}{|c|}{ Table 6: Growth in Funding } \\
\hline & (Mean percentages) \\
\hline Endowments (including Anchor Gifts) & $34 \%$ \\
\hline Grants/Contracts & $16 \%$ \\
\hline Sponsorships & $13 \%$ \\
\hline State Funds & $5 \%$ \\
\hline Membership fees & $4 \%$ \\
\hline Attendance fees & $2 \%$ \\
\hline Other & $26 \%$ \\
\hline Total & $100 \%$ \\
\hline
\end{tabular}

\section{DESCRIPTIVE RESULTS OF CENTER ACTIVITIES}

When asked what the primary mission of their center was, the overwhelming majority indicated that education was their goal. Seventy eight percent of our respondents indicated student education was their primary goal. A distant second was educating community entrepreneurs. The average self-reported efficacy in reaching this primary goal was 8.2 (on a 10 point scale with 10 defined as highly effective), or roughly a "B".

\begin{tabular}{|l|c|}
\hline \multicolumn{2}{|c|}{ Table 7: The Primary Mission of the Center } \\
\hline Education of the Students & $78 \%$ \\
\hline Education of community entrepreneurs & $11 \%$ \\
\hline New Venture Creation & $7 \%$ \\
\hline Networking & $2 \%$ \\
\hline Business Incubation & $2 \%$ \\
\hline Total & $100 \%$ \\
\hline
\end{tabular}

Table 8 describes the activities of the centers participating in our survey. Ninety one percent of the centers offer seminars and networking opportunities. Eighty percent of the centers offer courses for academic credit, with the average number of course offerings being nine. Almost eighty percent of the centers sponsor an awards ceremony and seventy percent host a business plan competition of some sort. For the centers responding to our survey, forty six percent of the activities were aimed at audiences internal to the institution, with an additional $27 \%$ of activities directed to 
audiences both internal and external to the institution. Only $27 \%$ of center activities were strictly aimed at audiences in the external community. Entrepreneurship education is thought to be best delivered "action-oriented, supportive of experiential learning, problem solving (and) project-based" (Jones and English, p. 422). The activities of academically based centers for entrepreneurship facilitate this pedagogy.

\begin{tabular}{|l|c|}
\hline \multicolumn{2}{|c|}{ Table 8: Center Activities } \\
\hline Seminars & Percentage of Centers \\
\hline Networking opportunities & $91 \%$ \\
\hline Courses for academic credit & $91 \%$ \\
\hline Award events & $80 \%$ \\
\hline Business plan competition & $79 \%$ \\
\hline
\end{tabular}

\section{DESCRIPTIVE RESULTS OF CENTER SUCCESS}

Table 9 describes the ways in which directors measure the success of their centers. The percentages do not sum to $100 \%$ because directors are likely to use multiple measures of success simultaneously. Sixty nine percent of the respondents report using enrollment in class as a measure of center success. Fifty eight percent track donor relations. Fifty three percent count attendance at seminars as a success factor. The "other" category included responses related to new business formation, faculty publications and general satisfaction measures, among others.

Three observations are apparent from the table. First, popular success metrics for center performance are indirect measures of center success. Second, there is a notable absence of financial results being used as success measures. Third, a sizable portion of the sample indicates that they do not formally measure the success of their centers $(16 \%)$.

Thirty five percent of the directors participating in this survey reported their centers had local or regional recognition. Thirty five percent of the directors also reported their centers had national recognition. Thirty percent of the directors believe their centers receive international recognition (100\% in total). The average self-reported rating on their overall center success was 7.9 (on a scale of 1 to 10 with 10 being completely successful), or a " $\mathrm{C}+$ ". 


\begin{tabular}{|l|l|}
\hline \multicolumn{2}{|c|}{ Table 9: Measures of Success } \\
\hline Enrollment in classes & $69 \%$ \\
\hline Donor relations & $58 \%$ \\
\hline Attendance at seminars & $53 \%$ \\
\hline Endowments & $49 \%$ \\
\hline Business plan competition awards & $45 \%$ \\
\hline Retention of sponsors & $33 \%$ \\
\hline Growth in budgets & $27 \%$ \\
\hline Graduation rates & $26 \%$ \\
\hline Other & $21 \%$ \\
\hline Do not formally measure success & $16 \%$ \\
\hline
\end{tabular}

\section{STATISTICAL ANALYSIS OF RELATIONSHIPS BETWEEN CENTER SUCCESS AND RESOURCES}

There has been very little theory development on effective management of entrepreneurial centers' resources, so exploratory correlational analysis between center resources, success and recognition was performed. Because this was an atheoretical exploration, the significant level was set at $\mathrm{p}<=.10$. The purpose of the analysis was to identify possible drivers of the outcome variables and to raise questions for future research.

A success scale was formed by summing three questions: "Overall, how would you rate the success of your center?"; "How effective is your center in accomplishing its primary mission?"; "How effective is your center in accomplishing its secondary mission?" Each question was measured on a ten point scale. The reliability of the summated success scale was more than adequate (Cronbach alpha $=.82$ ). Recognition of the centers was operationalized on a scale of geographic scope where center directors reported their centers were recognized: (1) locally/regionally, (2) nationally, (3) internationally.

These two outcome measures (Success and Recognition) were correlated with a wide variety of resource or input measures. Only a handful of correlations were found to be significant. The level of success was significantly and positively correlated with the level of funding for the chair $(\mathrm{r}=.43$, sig. @ .03); the number of graduate students $(\mathrm{r}=.28$, sig. @ .05) and the age of the center $(\mathrm{r}=.27$, sig. @.06). The level of staff resources was moderately correlated to Success $(\mathrm{r}=.25$, sig. @.08). But the level of faculty resources was not significantly correlated with Success or Recognition. 


\begin{tabular}{|l|c|c|}
\hline \multicolumn{2}{|c|}{ Table 10: Exploratory Correlations Between Resources and Success } \\
\hline & Success & Recognition \\
\hline Funding for Chair & .43 & \\
\hline No. of Grad. Students & .28 & \\
\hline Age of Center & .27 & \\
\hline No. of Undergrads.-. & 26 & .39 \\
\hline No. of Staff & .25 & .28 \\
\hline State Funding & & .28 \\
\hline Growth in State Funds & & \\
\hline "Other" Funding & & \\
\hline All correlations significant at $\mathrm{p}<=.10$ & & \\
\hline
\end{tabular}

There is logic to a self-reported measure of success being correlated to the level of chair funding, particularly if the reporter holds the chair. In the same vein, the longer a center has been in existence, the better the self-made case for success. Why the number of graduate students is correlated with success is not so apparent, as the number of undergraduates negatively correlated with the success of the center $(r=-.26$, sig. @.06). It may be that undergraduates chose institutions, while graduate students chose programs. Centers associated with successful entrepreneurship programs may have an advantage in attracting graduate students.

The scope of center recognition was positively correlated $(r=.28$, sig. @ .05) to the level of funding from "other" sources (tuition, government support). Recognition was positively correlated with the level of state funding (as a percentage of the total center budget), $(r=.39$, sig. @ .004), and growth in funding from state funds $(\mathrm{r}=.28$, sig. @.04). This result perhaps reflects a political acknowledgment of popularity. But overall growth in funding was not significantly correlated with either Success or Recognition. Funding sources other than state monies were not significantly correlated with either Success or Recognition.

\section{RESULTS FROM THE OPEN-ENDED QUESTIONS}

Respondents were asked "In your own words, what does it take to achieve excellence in an academically based entrepreneurship center?" The qualitative answers to this question were content analyzed and the results used to develop four categories which captured most of the responses. No attempt was made to establish a ranking or level of importance between the categories as many respondents gave multiple answers. As can be seen from the descriptions the categories are related and support each other. The categories are described below. 
The first category is Support from administrators and faculty. Support from administration was recognized by many of the respondents. Some typical answers include "Funding and support from administration who understand the value of entrepreneurship". Others said "100\% support from top university officers" or "Commitment from the top." Directors while recognizing the role of administration also acknowledged the importance of having faculty in support of the center as well. As one participant said "Commitment by tenured faculty to encourage support for developing courses and doing research in the field; support by the Dean, dedicated funds to the program and involvement of key entrepreneurial alum in the program."

The last part of the previous sentence suggests the importance of the second category: Strong relationships with the entrepreneurial community. As one respondent put it "Great connections with the business community." Another said "solid relationships with the business community" and "Hard work and a solid reputation in the community".

The close ties with business practitioners motivate the importance of the third category experiential learning. One individual said "A good balance of academic scholars and practitioners involved in the program as well as outstanding extracurricular learning opportunities." Another wrote "Practical, hands on learning opportunities."

The fourth category points out the importance of setting goals and staying on target. Many of the participants noted how easy it was to get distracted. One respondent said "It is too easy to become distracted by numerous constituencies, including institutional, business community, academic community, and peers to become involved in non-academic and non-entrepreneurship related activities." Other respondents focused on the importance of being mission driven, saying to be successful you must have "Vision, persistence, patience" or "Focus" and "Vision of what you want to become".

Respondents were also asked "In the next five years, what will be the most important challenges, issues or threats to the administration of academically based entrepreneurial centers? Again the results were content analyzed and four categories captured most of the responses.

It is possible to establish a sense of priority to the categorical responses dealing with the question of important challenges. Probably coming as no surprise to any current center director the most common answer dealt with funding. Many respondents said exactly that or put another way "more money". One respondent said "Money and qualified faculty are always in short supply."

The other three categories were more uniform in the number of responses to the question, so it is not possible to identify second, third or fourth priorities. Let us just say that a second category of challenges deals with the issue of establishing the legitimacy of entrepreneurship as an academic discipline. Several respondents noted the "Lack of credibility among traditional faculty" and "the struggle to be seen as more than just 'applied business' or revenue generator through programming."

A problem of popularity is contained in the third category: managing growth. Despite a legacy of illegitimacy, several directors indicated that their centers and programs were experiencing 
increased demand from students and the community. A center director said a significant challenge was "Handling major growth due to student interest in entrepreneurship." Another director highlighted the danger of growth by saying "Continued growing pains, including cross-campus expansion and its accompanying politics. Entrepreneurship centers have largely flown under the radar screen and have been successful by being entrepreneurial. Now they are at risk of becoming too 'corporate' or too 'academic' as they become vital parts of their institutions. As they grow, their ability to remain entrepreneurial becomes more threatened and they may begin to look and act like 'regular' academic centers, which are generally less vibrant and less innovative."

The previous quote contains the essence of the fourth category of challenges: extending entrepreneurship beyond the business school; "broadening technical and liberal arts entrepreneurial education opportunities", as one respondent put it. There are actually two perspectives captured in this category. One sees a challenge in offering entrepreneurship education to more than just business students. This perspective is found in the quote "It is critical the entrepreneurship education be available in a substantive way to all university students, not just business students." The expansion of the role of entrepreneurship is taken even further with the quote "I think academic centers will be increasingly called upon to extend beyond the domain of business schools -- to address issues of national innovation (scientists as entrepreneurs) and national security (terrorists are viewed as entrepreneurial -- how do we bring up a generation of people who can match them in their thinking?)". But a second perspective warns that entrepreneurial education may be threatened by "Loss of autonomy as entrepreneurship education is sought by more population groups who are administered by varying institutional units".

Recent research suggests that deans are favorably disposed towards broadening entrepreneurial education beyond the business school(Menzies 2004). Therefore this challenge will become increasingly important to center directors.

\section{OBSERVATIONS FROM THE STUDY}

Even though this paper reports the results of a descriptive and exploratory study with a relatively small sample size, there are still many useful observations to be made as to the structure and functioning of academically based entrepreneurship centers. First, looking at how centers tend to measure success, one can see that indirect measures are commonly employed. The primary goal of most centers is the education of students but no specific learning outcome measure was reported. On average only twenty six percent of the respondents track graduation rates. The number of centers in our study that measure students employment in entrepreneurial settings, or the number of business start-ups associated with center activities is less than a handful. Input measures such as class enrollment, endowments, and attendance are more popular.

It is easier to assess center performance using indirect input measures but these measures do not really measure the effectiveness of the center at fostering successful entrepreneurs. The 
difficulty in assessing the effectiveness of entrepreneurial education programs has been noted by others (Henry, Hill \& Leitch, 2005). But, as the academic legitimacy and growth of center influence continues, it will become increasingly important to justify efficacy to important constituencies.

A second observation is the weak or no correlation between center resources (faculty, staff, funding), activities and success/recognition. This may be a limitation due to the study design and sample. The observation might also be explained by the use of indirect measures of success, as discussed earlier. Center recognition may be more effectively achieved through public service by the directors which results in positive community and professional relations. Centers' success may also be a function of students' background and abilities developing in entrepreneurial environments.

Recognizing that academically based entrepreneurship centers are not-for-profits, there still appears to be room to improve the business "discipline" for many operations. A substantial number of the centers in the study do not engage in strategic planning. Many do not have an advisory board, and a number do not formally measure success in any fashion. In an era of increasing competition for funds and a concurrent interest in organizational accountability, it behooves center directors to improve their governance procedures and operating policies.

Perhaps the overriding observation from the study is that entrepreneurship and centers in support of entrepreneurial education are increasing in popularity. The evidence is seen in the number of centers in this study that are less than five years old. It is seen in the qualitative responses that center directors gave when questioned about future challenges. Popularity and growth give rise to problems of inadequate funding and serving too many masters.

\section{IMPLICATIONS FOR NEW OR EARLY-STAGE CENTERS}

Perhaps the most obvious lesson from the study is that adequate and sustainable funding should be secured early in the development of the center. Centers in this study did not use attendance or membership fees as a significant source of income. Center directors are advised to actively pursue endowments and grants/contracts.

Endowments and experiential learning opportunities come from the entrepreneurial business community. The success of a center and its director is tied to the strength of the liaison between the center and entrepreneurs.

Centers also need support from faculty and senior administration. It would therefore appear that center directors should have highly developed personal selling skills as well as administrative talents. In order to keep these varied and often contrary constituents satisfied a set of outcome variables should be defined. Examples of such variables include tracking the entrepreneurial employment history of students, post graduation or the number of ventures created by students and graduates.

Journal of Entrepreneurship Education, Volume 9, 2006 
The functioning of centers will be improved with the integration of certain business practices. These practices include formulating an advisory board and engaging in strategic planning. A strong statement of mission should be integral to the strategic planning process.

Finally, centers should be student driven. People do not give money to programs, centers or institutions. They give money to provide opportunity to students. Making a difference in a student's life is a powerful selling point to all constituent groups and a strong justification for an entrepreneurial center's existence.

\section{IMPLICATIONS FOR FUTURE RESEARCH}

The findings from this inquiry into purposes and practices of academic centers for entrepreneurship give rise to the following questions for further research:

Why is the number of faculty resources and involvement of faculty reported as insignificant by the directors of entrepreneurship centers when the majority of centers express education of students as the primary mission?

What is the impact of a center's resources (faculty, funding, funding type, staff) verses activities (networking, community programming, etc) on success and recognition?

Is there parity between the perspectives of center directors and institutional representatives (administrators and faculty)?

How do the center directors determine the level of local, national, regional recognition?

With the apparent expanding mandate for providing entrepreneurial education to undergraduate students outside of schools of business, what will be the effects on: indirect/direct measures of success, operational dynamics, internal/external focus, funding sources, reporting relationships, and job description of center directors?

What factors determine the presence, absence, efficacy of strategic planning in a center for entrepreneurship?

How do the academic/ non academic qualifications of the center director shape the activities of the center?

Entrepreneurship is seen as an appropriate response to an increasing volatile and competitive economic environment. Traditional education and research methodologies employed by business schools have been found wanting (Kirby 2004). Academically based entrepreneurship centers are important innovations leading to improving entrepreneurial theory and practice. This study is a preliminary step to understanding and improving the structure and functioning of academically based entrepreneurship centers. 


\section{REFERENCES}

Bechard, J-P., \& D. Gregoire (2005). Entrepreneurship Education Research Revisited: The Case of Higher Education. Academy of Management Learning \& Education, 4(1), 22-43.

Henry, C., Hill F. \& Leitch C. (2005). Entrepreneurship education and training: can entrepreneurship be taught, Part I \& Part II. Education \& Training, 47(2/3), 98-116, 158-170.

Jones, C. \& English J. (2004). A contemporary approach to entrepreneurship education. Education \& Training, 46(8/9) 416-423

Katz, J.A. (2003). The chronology and intellectual trajectory of American entrepreneurship education 1876-1999. Journal of Business Venturing, 18(2), 283-300.

Kirby, D.A. (2004). Entrepreneurship education: can business schools meet the challenge? Education \& Training, 46(8/9), 510-519.

Menzies, T.V. (2004). Are universities playing a role in nurturing and developing high technology entrepreneurs? The administrators' perspective. International Journal of Entrepreneurship and Innovation, 5(3), 149-157.

Solomon, G.T., S. Duffy, \& A. Tarabishy (2002). The State of Entrepreneurship Education in the United States: A Nationwide Survey and Analysis. International Journal of Entrepreneurship Education, 1(1), 1-22. 


\title{
MANAGING BUSINESS PLANNING PROJECTS IN ACADEMIA
}

\author{
Colin Benjamin, Florida A \& M University \\ Booker Warren, Florida A \& M University \\ Janée Burkhalter, Florida A \& M University
}

\begin{abstract}
In this paper, we identify the challenges encountered by student teams when developing business plans in academia. We describe a robust planning framework developed to facilitate management of these projects and illustrate its application via case studies in the development of business plans for lifestyle, technology-based, and real-estate businesses in the School of Business \& Industry at Florida $A$ \& $M$ University.
\end{abstract}

\section{INTRODUCTION}

Business planning is important to the success of any organization. The business plan can help an organization arrive at a nice balance between reach and realism by developing a written summary of what the organization hopes to accomplish and how it intends to organize its resources. Business plans can provide focus, assist in driving system enhancements, and provide a basis for setting priorities and allocating scarce resources. A business plan is, in effect, a road map for an organization that sells the company and its mission to its stakeholders (Jones, 2000).

In academia, business planning occupies a central place in entrepreneurship curricula as core courses invariably incorporate coursework which require students, working in small teams to develop business plans. Student teams are encouraged to participate in business plan competitions, sponsored by both academic and non-academic institutions, which offer substantial cash prizes and provide great opportunities for refining business concepts. One good example of effective university sponsorship is the MOOT Corp global business plan competition (Cadenhead, 2002) hosted by the University of Texas-Austin which has grown exponentially over the past twenty five years and now provides an excellent forum for student teams from all continents to develop and present business plans to prospective investors and compete for significant cash prizes. Yale University's New Ventures Challenge competition (www.ventures.yale.edu) provides similar opportunities for student teams working on business plans for non-profit organizations. Non-academic competitions include the Ford BEST Business Plan Contest sponsored by Ford Motor Company in association with SCORE and Diversity Inc. (Brown, 2004). In this contest, plans are judged based on criteria such as viability, benefit to the community, anticipated sales and funding requirements. Other examples 
are PLANedu launched in 2000 by Garage.com for full-time students at accredited U.S. colleges and universities, and the B-Plan challenge founded by Startemup.com, a group of Duke university graduates, to facilitate networking among university entrepreneurs (Seymour, 2002).

Students are not always able to have the ideal complement of skills on their teams and often need assistance in all phases of the business planning process. Selecting a business concept that has the full support of the team members, conducting the studies in marketing, operations and finance needed to develop a realistic plan of action, selecting business planning software to assist in plan development, assembling the written plan, delivering a convincing oral presentation, and preparing for the question and answer session, all have to be completed to meet strict milestones as dictated by the course schedule. Resources are limited by meager academic budgets and students have to demonstrate considerable initiative to enable the completion of a quality business plan in a timely manner. Innovative approaches must be adopted by faculty members faced with the challenge of teaching these large classes with several student teams to assist the teams in rapidly understanding the business planning process and ably marshalling the teams' resources to meet all deadlines. Faculty members can benefit from a replicable planning framework that helps student teams quickly identify, research and execute the activities associated with the business planning process and take ownership of their business plans.

In this paper, we describe a robust planning framework developed to facilitate the management of business planning projects in academia. We identify the several challenges encountered by student teams in developing business plans and illustrate the application of our planning framework via case studies in the development of business plans for lifestyle, technologybased, and real estate businesses at the School of Business \& Industry at Florida A \& M University,

\section{BUSINESS PLANNING IN ACADEMIA}

The literature contains a wealth of information on creating successful business plans (Gumpert, 1997), and on developing business plans for product-oriented businesses (Cohen, 1995), service businesses (Cohen, 1995), and E-Commerce companies (Eglash, 2000). Appendix 1 provides a listing of a sample of the many websites which provide useful background information on the various aspects of business planning. However, little guidance is provided for faculty faced with the challenges of directing business planning projects assigned to student teams in academia. Never-the-less, in virtually all entrepreneurship programs in academia, students working in small teams are required to identify a business concept of interest and develop a written business plan. Success requires the rapid development of an action plan with clearly defined milestones and ongoing intra-team communication and collaboration to facilitate timely completion of the plan.

Journal of Entrepreneurship Education, Volume 9, 2006 


\begin{tabular}{|c|}
\hline x 1: Informational Web Sites for Business Planning \\
\hline $\begin{array}{l}\text { ActionSearch - www.actionsearch.com } \\
\text { Go to "ActionSearch Engine" window and enter "business plans." The site provides numerous valuable } \\
\text { business planning LINKS such as: business plan software reviews, sample business plans, startup } \\
\text { issues, finance issues, strategy and forecasting issues. Also links to business planning resources such as } \\
\text { American Express, MIT, PriceWaterhouseCoopers, US Small Business Administration, and others." }\end{array}$ \\
\hline $\begin{array}{l}\text { Babson College: Horn Library; www.fusion.babson.edu/html/library/ } \\
\text { This site includes many valuable LINKS such as "Research Guides from A-Z where topics include } \\
\text { Business Plan Research, Business Plan "How-To's and Examples," and Entrepreneurship Advice for } \\
\text { Starting and Running a Business. }\end{array}$ \\
\hline $\begin{array}{l}\text { CELCEE The Kauffman Center for Entrepreneurial Leadership Clearinghouse on Entrepreneurship } \\
\text { Education, www.celcee.edu } \\
\text { This site has digests on entrepreneurial education and business planning research links. }\end{array}$ \\
\hline $\begin{array}{l}\text { Ernst \& Young www.ey.com } \\
\text { In the search window, enter "Outline for a Business Plan." Additionally, they offer ERNIE, an Online } \\
\text { Business Consultant. ERNIE provides in depth, cost effective advice on virtually any tax audit or } \\
\text { business consulting topic. }\end{array}$ \\
\hline $\begin{array}{l}\text { Harvard Business Review www.harvardbusinessonline.hsb.harvard.edu } \\
\text { Articles and how-to publications for entrepreneurs. One business planning tool available online is: } \\
\text { Harvard ManageMentor Module: Preparing a Business Plan (Product\# 8415). }\end{array}$ \\
\hline $\begin{array}{l}\text { Leeds Business School, University of Colorado, www.leeds-faculty.colorado.edu/lawrencs/bplan } \\
\text { Business Plan Preparation section includes tools for writing business plans. Content examples include } \\
\text { Outline of a Successful Business Plan, Twelve Steps to a Successful Business Plan, Quick Start, } \\
\text { Feasibility Study, Sample Business Plans, and Reference Links. }\end{array}$ \\
\hline $\begin{array}{l}\text { MOOT Corp. Competition, University of Texas at Austin, www.mootcorp.org/index.asp } \\
\text { This site provides information on the annual global business plan competition sponsored by the } \\
\text { University of Texas-Austin McCombs Business School. The site affords access to winning business } \\
\text { plans from recent MOOT Corp competitions. }\end{array}$ \\
\hline $\begin{array}{l}\text { Opportunity Funding Corporation Venture Challenge (OFCVC), www.ofcvc.org } \\
\text { This site provides information on the annual business plan competition sponsored by OFCVC for } \\
\text { students at Historically Black Colleges and Universities (HBCUs). The site also provides a } \\
\text { comprehensive listing of information sources for students developing business plans. }\end{array}$ \\
\hline $\begin{array}{l}\text { Palo Alto Software, Inc., Bplans.com, www.bplans.com } \\
\text { Site contains articles and advice on a variety of business planning topics. It is especially useful when } \\
\text { using the Business Plan Pro business planning software. }\end{array}$ \\
\hline $\begin{array}{l}\text { Small Business Administration: www.sbaonline.sba.gov/starting/businessplan.html } \\
\text { Business plan outlines and extensive business planning instructions including financial data, marketing } \\
\text { data, and excellent links. }\end{array}$ \\
\hline $\begin{array}{l}\text { Yale-Goldman Sachs Partnership on Nonprofit Ventures. www.ventures.yale.edu/brieftutorial.asp } \\
\text { Brief Tutorial on Business Planning for Nonprofit Enterprise; Extensive Library and Bibliography. } \\
\text { Sample business plans can also be downloaded. }\end{array}$ \\
\hline
\end{tabular}


Our approach at the School of Business \& Industry, FAMU has been to adopt well-proven project management strategies employed by industry. A general project plan is developed to provide a road-map for student teams in developing the business plan. This plan establishes the project tasks, estimates task durations and identifies the important milestones. Student teams are then required to assign specific roles and responsibilities to team members and are asked to submit periodic written and oral progress reports. To facilitate timely project completion, the full range of project planning and control techniques is used. These include intra-team review meetings, in-class review sessions, project websites, discussion groups using course management software, and virtual team meetings. These techniques have proven effective in managing large team projects in academia (Benjamin et al, 2001).

At the end of the semester, each team should have completed a written business plan to record the major highlights of the proposed new venture, and deliver an oral presentation to report the major findings to the class, interested students and faculty. The final written business plan is structured to include, where appropriate, the following:-

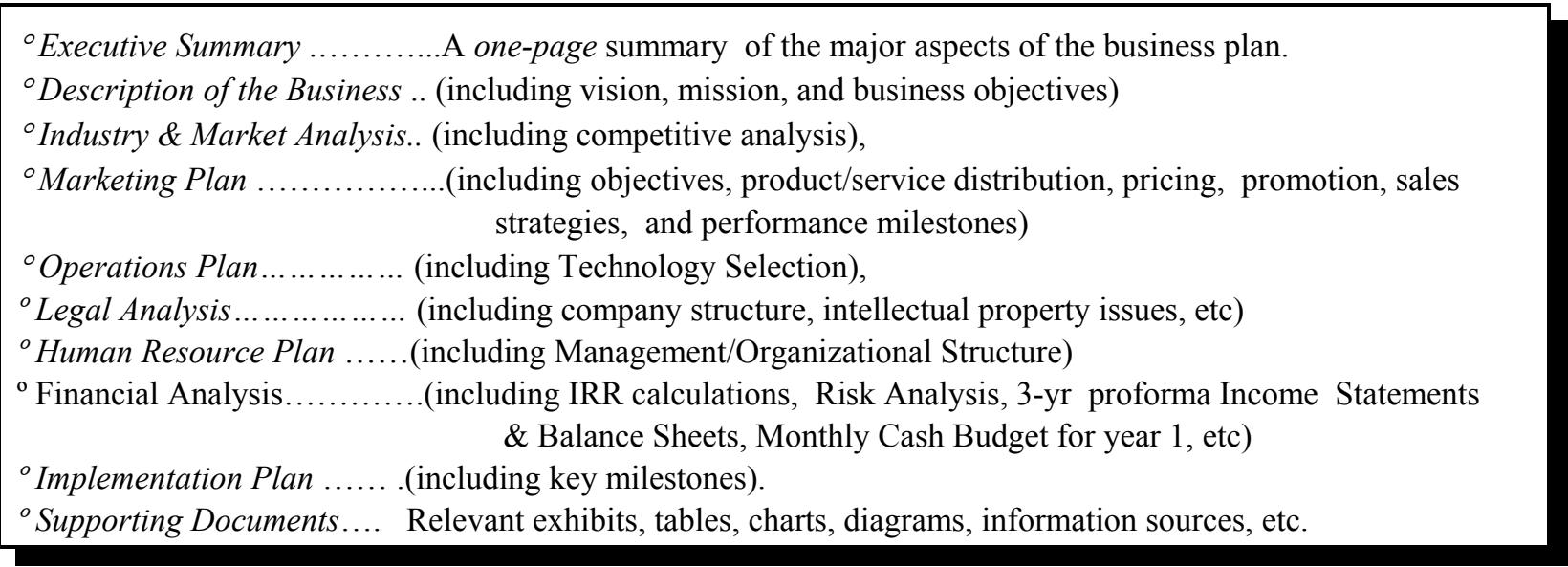

\section{BUSINESS PLANNING SOFTWARE}

Writing a business plan can be intimidating when undertaken for the first time. However, students who are motivated and focused can marshal the resources required to create an actionable plan. Although access to resource personnel with expertise in the selected business concept is essential, books and content guidelines can be very helpful to students (Sahlman, 1996; Covello and Hazelgreen, 1994; Berry, 1999).

Business planning software goes a step further than books and guidelines by providing "wizards" and "templates" that prompt users through a detailed list of potential subjects. Canned text may also be available for use as a starting point in developing some sections of the plan. The writer has this assistance when picking the topics that are important to the focus of the plan. 
Software packages usually include a written manual, which is sometimes an excellent aid for students.

\begin{tabular}{|c|c|c|c|c|c|c|c|c|c|c|c|}
\hline \multicolumn{12}{|c|}{ Appendix 2: Sample of Commercially Available Business Planning Software } \\
\hline \multirow[t]{2}{*}{$\begin{array}{c}\text { Software } \\
\text { Title }\end{array}$} & \multirow{2}{*}{$\begin{array}{l}\text { Vendor } \\
\text { Name } \\
\text { \& URL }\end{array}$} & \multicolumn{2}{|c|}{$\begin{array}{l}\text { Operating } \\
\text { System }\end{array}$} & \multicolumn{8}{|c|}{ Software Features } \\
\hline & & $\begin{array}{l}\text { Win- } \\
\text { dows }\end{array}$ & Mac & $\begin{array}{c}\text { User } \\
\text { Manual }\end{array}$ & $\begin{array}{l}\text { Wiz- } \\
\text { ard or } \\
\text { Tem- } \\
\text { plate }\end{array}$ & $\begin{array}{c}\text { Compati } \\
\text { bility }\end{array}$ & $\begin{array}{l}\text { Sample } \\
\text { Plans }\end{array}$ & $\begin{array}{l}\text { Special } \\
\text { Features }\end{array}$ & Price & $\begin{array}{l}\text { Tech } \\
\text { Support }\end{array}$ & $\begin{array}{c}\text { Research } \\
\text { Links }\end{array}$ \\
\hline Adarus & $\begin{array}{l}\text { Adarus } \\
\text { Software } \\
\text { LLC, } \\
\text { www. } \\
\text { adarus. } \\
\text { com }\end{array}$ & yes & no & yes & yes & $\begin{array}{l}\text { Microsoft } \\
\text { Word } \\
\text { \& Excel }\end{array}$ & None & $\begin{array}{l}\text { No frills. } \\
\text { VBasic } \\
\text { front end } \\
\text { to Word } \\
\text { \& Excel }\end{array}$ & $\$ 60$ & yes & no \\
\hline $\begin{array}{l}\text { Auto- } \\
\text { mate } \\
\text { Your } \\
\text { Business } \\
\text { Plan } 11.0\end{array}$ & $\begin{array}{c}\text { Out of } \\
\text { Your Mind } \\
\text {...And Into } \\
\text { The } \\
\text { Market- } \\
\text { place, } \\
\text { 'www.busin } \\
\text { ess- } \\
\text { plan.com }\end{array}$ & yes & yes & yes & yes & $\begin{array}{c}\text { Microsoft } \\
\text { Word, } \\
\text { Excel \& } \\
\text { Power- } \\
\text { Point }\end{array}$ & $\begin{array}{c}\text { Three } \\
\text { complete } \\
\text { plans } \\
\text { (one } \\
\text { dot.com) }\end{array}$ & $\begin{array}{l}\text { Links to } \\
\text { marketing } \\
\text { \& financial } \\
\text { research } \\
\text { sites }\end{array}$ & 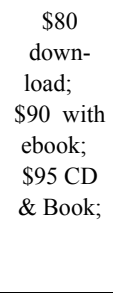 & yes & yes \\
\hline $\begin{array}{l}\text { Biz } \\
\text { Plan } \\
\text { Write }\end{array}$ & $\begin{array}{c}\text { Jian Tools } \\
\text { For Sales; } \\
\text { www. } \\
\text { jianusa. } \\
\text { com }\end{array}$ & yes & no & yes & yes & $\begin{array}{l}\text { Microsoft } \\
\text { Word \& } \\
\text { Excel }\end{array}$ & $\begin{array}{c}7 \text { sample } \\
\text { plans }\end{array}$ & $\begin{array}{l}\text { Import } \\
\text { from } \\
\text { Quick- } \\
\text { books, Add } \\
\text { data to } \\
\text { Power- } \\
\text { Point }\end{array}$ & $\$ 99.99$ & yes & no \\
\hline $\begin{array}{l}\text { Business } \\
\text { Plan Pro }\end{array}$ & $\begin{array}{l}\text { Palo Alto } \\
\text { Software, } \\
\text { Inc. www. } \\
\text { paloalto. } \\
\text { com }\end{array}$ & yes & no & yes & yes & $\begin{array}{c}\text { Microsoft } \\
\text { Word, } \\
\text { Excel \& } \\
\text { Power- } \\
\text { Point }\end{array}$ & $\begin{array}{c}400 \\
\text { sample } \\
\text { plans }\end{array}$ & $\begin{array}{c}\text { Automatic } \\
\text { updates \& } \\
\text { patches. } \\
\text { Power- } \\
\text { Point } \\
\text { templates. } \\
\text { Non-profit } \\
\text { format } \\
\text { available }\end{array}$ & $\begin{array}{c}\$ 99.95 \\
\text { Standard } \\
\$ 199 \\
\text { Premier } \\
\text { Edition }\end{array}$ & $\begin{array}{l}\text { phone } \\
\& \text { email }\end{array}$ & yes \\
\hline $\begin{array}{l}\text { Business } \\
\text { Plan } \\
\text { Writer } \\
\text { Deluxe }\end{array}$ & $\begin{array}{l}\text { Nova } \\
\text { Develop- } \\
\text { ment } \\
\text { www. } \\
\text { nova } \\
\text { develop- } \\
\text { ment.com }\end{array}$ & yes & no & yes & yes & $\begin{array}{c}\text { Microsoft } \\
\text { Office \& } \\
\text { Quick- } \\
\text { Books Pro }\end{array}$ & $\begin{array}{c}260 \\
\text { business } \\
\text { plans }\end{array}$ & $\begin{array}{l}\text { Click art, } \\
\text { industry } \\
\text { reports, and } \\
\text { legal forms }\end{array}$ & $\$ 99.95$ & yes & yes \\
\hline $\begin{array}{l}\text { Fundable } \\
\text { Plans }\end{array}$ & $\begin{array}{c}\text { Strategic } \\
\text { Services } \\
\text { Group, } \\
\text { www. } \\
\text { fundable- } \\
\text { plans.com }\end{array}$ & email & email & yes & yes & $\begin{array}{c}\text { Plan is } \\
\text { delivered } \\
\text { via email as } \\
\text { an Adobe } \\
\text { Acrobat } \\
\text { (.pdf) file. }\end{array}$ & $\begin{array}{l}\text { Links to } \\
\text { article } \\
\text { and } \\
\text { example } \\
\text { from } \\
\text { Fund-able } \\
\text { Plans }\end{array}$ & $\begin{array}{c}\text { Creates } \\
\text { plan in } \\
\text { Adobe } \\
\text { Acrobat } \\
\text { and ships } \\
\text { via email. } \\
\text { Upload \& } \\
\text { use } \\
\text { graphics }\end{array}$ & $\$ 39.95$ & yes & yes \\
\hline
\end{tabular}




\begin{tabular}{|c|c|c|c|c|c|c|c|c|c|c|c|}
\hline \multirow[t]{2}{*}{$\begin{array}{c}\text { Software } \\
\text { Title }\end{array}$} & \multirow{2}{*}{$\begin{array}{l}\text { Vendor } \\
\text { Name } \\
\text { \& URL }\end{array}$} & \multicolumn{2}{|c|}{$\begin{array}{c}\text { Operating } \\
\text { System }\end{array}$} & \multicolumn{8}{|c|}{ Software Features } \\
\hline & & $\begin{array}{l}\text { Win- } \\
\text { dows }\end{array}$ & Mac & $\begin{array}{c}\text { User } \\
\text { Manual }\end{array}$ & $\begin{array}{l}\text { Wiz- } \\
\text { ard or } \\
\text { Tem- } \\
\text { plate }\end{array}$ & $\begin{array}{c}\text { Compati } \\
\text { bility }\end{array}$ & $\begin{array}{l}\text { Sample } \\
\text { Plans }\end{array}$ & $\begin{array}{l}\text { Special } \\
\text { Features }\end{array}$ & Price & $\begin{array}{l}\text { Tech } \\
\text { Support }\end{array}$ & $\begin{array}{c}\text { Research } \\
\text { Links }\end{array}$ \\
\hline $\begin{array}{l}\text { Plan } \\
\text { Magic }\end{array}$ & $\begin{array}{c}\text { PlanMagic } \\
\text { Corp., } \\
\text { www.plan } \\
\text { magic.com }\end{array}$ & yes & no & yes & yes & $\begin{array}{l}\text { Microsoft } \\
\text { Office }\end{array}$ & $\begin{array}{c}\text { Only } \\
\text { Industry } \\
\text { Tem- } \\
\text { plates }\end{array}$ & $\begin{array}{c}\text { Restaurant } \\
\text { business } \\
\text { plans are a } \\
\text { speciality }\end{array}$ & $\begin{array}{l}\$ 84.95 \text { to } \\
\$ 149.95\end{array}$ & yes & no \\
\hline $\begin{array}{l}\text { Plan } \\
\text { Write }\end{array}$ & $\begin{array}{c}\text { Business } \\
\text { Resource } \\
\text { Software } \\
\text { Inc. } \\
\text { 'www. } \\
\text { brs-inc. } \\
\text { com }\end{array}$ & yes & no & yes & yes & $\begin{array}{c}\text { Microsoft } \\
\text { Word, } \\
\text { Excel \& } \\
\text { Power- } \\
\text { Point }\end{array}$ & $\begin{array}{c}\text { Library } \\
\text { of Plans, } \\
\text { including } \\
\text { Moot } \\
\text { Corp } \\
\text { Award } \\
\text { Winners }\end{array}$ & $\begin{array}{c}\text { Gives } \\
\text { marketing } \\
\text { strategy } \\
\text { advice }\end{array}$ & $\$ 229.95$ & yes & yes \\
\hline $\begin{array}{l}\text { Smart } \\
\text { Business } \\
\text { Plan }\end{array}$ & $\begin{array}{c}\text { Smart } \\
\text { Online Inc. } \\
\text { www. } \\
\text { smart } \\
\text { online. } \\
\text { com }\end{array}$ & yes & no & $\begin{array}{l}\text { Online } \\
\text { manual }\end{array}$ & yes & $\begin{array}{l}\text { Microsoft } \\
\text { Office }\end{array}$ & $\begin{array}{c}10 \\
\text { sample } \\
\text { plans }\end{array}$ & $\begin{array}{c}\text { Excellent } \\
\text { graphics. } \\
\text { A range of } \\
\text { fee-based } \\
\text { services } \\
\text { available. }\end{array}$ & $\begin{array}{c}\text { Sub- } \\
\text { scription- } \\
\$ 29.95 / \\
\text { month; } \\
\text { Business } \\
\text { Plan - } \\
\$ 499.95\end{array}$ & yes & yes \\
\hline
\end{tabular}

Business Planning software packages can alleviate the problem of starting from scratch by providing a structure for the plan. These packages generally ask questions to extract the most important, underlying concepts within your business idea. Appendix 2 provides a tabular summary of profiles of several business plan software packages. These software packages typically interface with Microsoft Word, Excel and usually with PowerPoint and QuickBooks. Some of them need a web browser to connect users with their sample business plans and provide links to a rich variety of information sources. Adobe's Acrobat Reader is also needed for some more sophisticated software.

The software packages described in Appendix 2 are moderately priced with prices ranging from $\$ 95$ to $\$ 229.95$. One of the more popular business plan software is Business Plan Pro Premier Edition distributed by Palo Alto Software. This product, developed by Tim Berry, a business planner/consultant since 1974, has secured benefits from many years of use and improvement. Another product which has received favorable reviews is PlanWrite Expert Edition developed by Business Resource Software, Inc. (BRS). BRS, founded in 1989, stresses the utilization of its expertise in artificial intelligence as well as competitive strategy and industry analysis. They cite Michael Porter and Boston Consulting as two of the many expert sources whose principles are incorporated into their software/analytical tools. Automate Your Business Plan 11.0, another promising business planning software, is produced by an entrepreneur with 17 years experience as a business planner, consultant, and software developer. Reviews indicate this software is very user 
friendly and that it has the elements needed to produce a complete and professional looking business plan. However, in many cases, student teams still opt to utilize the ubiquitous office productivity tools for word processing, spreadsheet model building, and report preparation such as those provided by Microsoft Office, in creating unique business plans tailored to best present their business case.

\section{ROLE OF PROJECT MANAGEMENT SOFTWARE}

When developing a work plan to facilitate timely completion of their business plans, student teams sometimes explore the use of commercially available project management software. Several project management software surveys are available from professional organizations such as the Project Management Institute (PMI) and the Institute of Industrial Engineers (IIE). These surveys describe the wide range of project management software available to today's progressive managers to aid in planning, implementing and control of projects. Several vendors offer a suite of products capable of running on several platforms. One survey published by the Institute of Industrial Engineers (IIE) (Elliot, 2001) provides profiles of 47 software products marketed by 35 companies with prices ranging from $\$ 49$ to $\$ 1,000,000$. These software range from low-cost programs such as Milestones which have limited functionality to the more expensive programs such as Artemis and Primavera which offer a comprehensive suite of features. Although software was available to run on several operating systems, Windows was still the dominant platform. The vendors were dispersed throughout the U.S. and most of them typically sold one product. However, there were a few who offered a suite of 2-3 products.

To facilitate the deployment of Project Management Software to aid business planning projects in academia, faculty members will benefit from the implementation of a generalized project network to facilitate the rapid development of a business plan. In this project, we develop a logic network diagram that models the business planning process and illustrate its implementation in academia using the Microsoft MS Project 2003 software.

\section{PROPOSED PLANNING FRAMEWORK}

The task list in Table 1 describes the activities typically associated with the development of a business plan and specifies the precedence relationships among the activities. Figure 1 shows how this information can be combined into a Logic Network to summarize the process being used to implement this generalized business planning project. Once estimates are made for duration of the tasks based on specified resource allocations and the costs of the resources, this project planning information can be input into a project management software program to develop a planning schedule with a related project budget. In academia, the project schedule in the form of a network diagram, Gantt chart, or milestone chart, is the most important planning document as it provides clear project milestones which can be used as a baseline to monitor and control project performance. 
Table 1: Task List for Business Planning Project

\begin{tabular}{|c|c|c|c|c|c|}
\hline $\begin{array}{l}\varrho \\
\frac{\vec{v}}{\tilde{E}} \\
\stackrel{E}{E}\end{array}$ & Task Description & 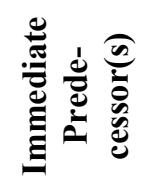 & $\begin{array}{l}\varrho \\
\frac{\pi}{\tilde{E}} \\
\tilde{\sigma}\end{array}$ & Task Description & 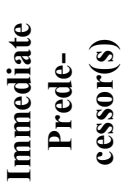 \\
\hline$A$ & $S T A R T$ & ---- & $\boldsymbol{K}$ & Develop Prelim. Business Plan & $\mathrm{J}$ \\
\hline $\boldsymbol{B}$ & Determine Project Scope & A & $L$ & Project Review \#2 & $\mathrm{K}$ \\
\hline$C$ & Conduct Literature Review & $\mathrm{B}$ & $M$ & Conduct Risk Analysis & $\mathrm{L}$ \\
\hline $\boldsymbol{D}$ & Select Business Concept & B & $N$ & Conduct Supplementary Analysis & $\mathrm{L}$ \\
\hline $\boldsymbol{E}$ & Project Review \#1 & C, D & $\boldsymbol{O}$ & Develop Final Business Plan & $\mathrm{M}, \mathrm{N}$ \\
\hline $\boldsymbol{F}$ & Conduct Market Analysis & $\mathrm{E}$ & $\boldsymbol{P}$ & Prepare Oral Presentation & $\mathrm{O}$ \\
\hline $\boldsymbol{G}$ & Conduct Technology Study & $\mathrm{E}$ & $Q$ & Submit Written Report & $\mathrm{O}$ \\
\hline $\boldsymbol{H}$ & Conduct Operations Analysis & $\mathrm{E}$ & $\boldsymbol{R}$ & Make Oral Presentations & $\mathrm{P}, \mathrm{Q}$ \\
\hline$I$ & Conduct Legal Analysis & $\mathrm{E}$ & $\boldsymbol{S}$ & FINISH & $\mathrm{R}$ \\
\hline $\boldsymbol{J}$ & Conduct Financial Analysis & $\mathrm{F}, \mathrm{G}, \mathrm{H}, \mathrm{I}$ & & & \\
\hline
\end{tabular}

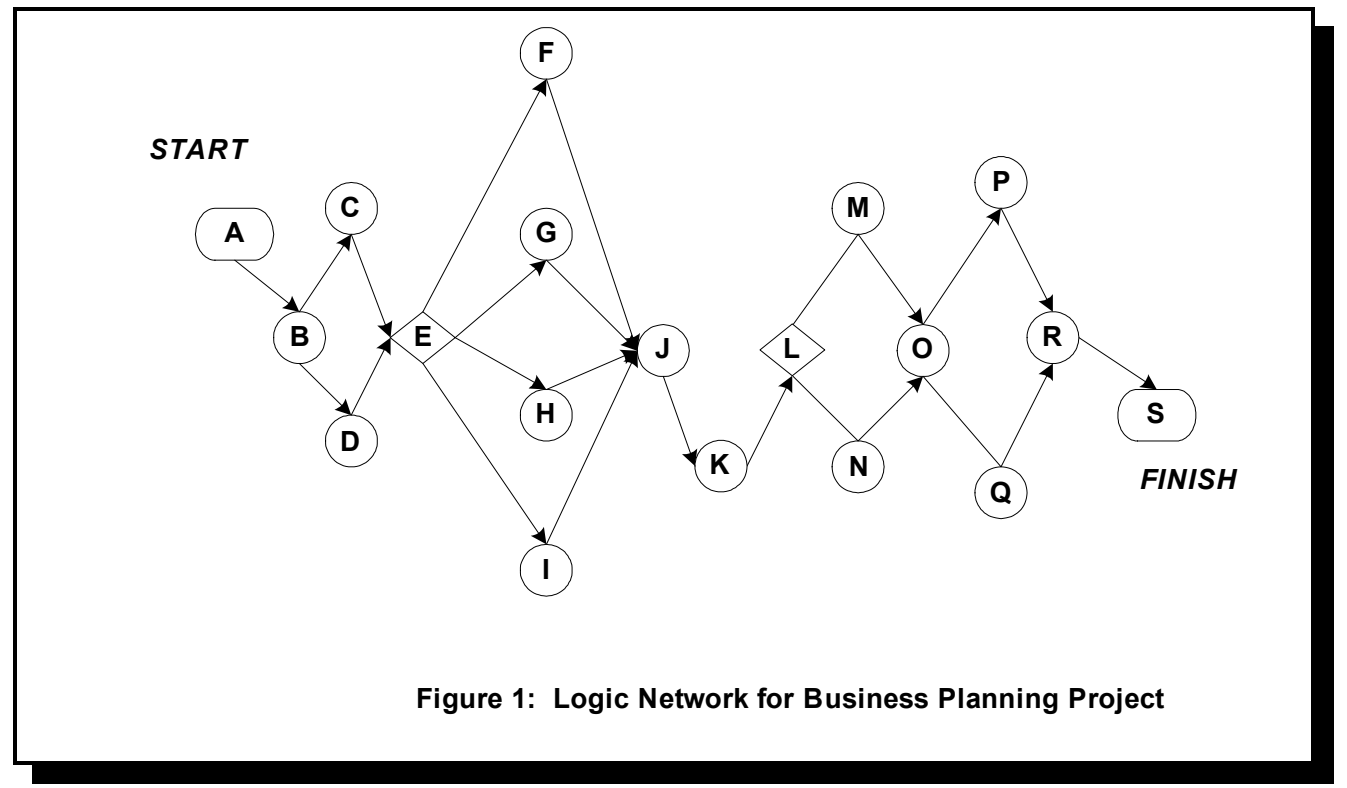

\section{CASE STUDIES FROM ACADEMIA}

The planning framework outlined in Figure 1 has been successfully employed since 2001 to manage numerous business planning projects in the School of Business and Industry at Florida A 
\& M University. These projects range from developing plans for simpler lifestyle businesses which are completed in a semester to the more complex plans for technology-based businesses and realestate ventures which are completed after preliminary technology commercialization or prefeasibility studies. Microsoft Project 2000 project management software has been used to facilitate rapid development of a project plan and to provide a basis for monitoring implementation.

This approach was used successfully to guide the efforts of numerous teams of 4-6 students in developing business plans for lifestyle businesses at the School of Business and Industry, Florida A \& M University. The business concepts explored included:

\begin{tabular}{|l|l|l|}
\hline Internet Café & Business Consulting & Ethnic Restaurants \\
\hline Fitness Centers & Car Wash & Beverage Distribution \\
\hline Ice Cream Distribution & Night Clubs & Day Spas \\
\hline
\end{tabular}

These business concepts were all familiar to students and planning information was readily available through our university Small Business Development Center and internet sources. The challenge facing each team was to develop a viable business model to justify launching the new venture and to conduct the relevant support studies in Marketing, Operations, and Finance required to present a winning plan. Table 2 summarizes the logic and estimates of task durations used in developing the plan. As shown in Figure 2, the project should be completed in 59 working days with the critical path being activities A-B-C-E-F-J-K-L-N-O-Q-S.

\begin{tabular}{|c|l|c|c|}
\hline \multicolumn{5}{|c|}{ Table 2: Planning Information for Business Planning Project } \\
\hline Task ID & \multicolumn{1}{|c|}{ Task Description } & Duration (days) & Predecessor(s) \\
\hline $\boldsymbol{A}$ & START & 0 & --- \\
\hline $\boldsymbol{B}$ & Determine Project Scope & 1 & $\mathrm{~A}$ \\
\hline $\boldsymbol{C}$ & Conduct Literature Review & 6 & $\mathrm{~B}$ \\
\hline $\boldsymbol{D}$ & Select Business Concept & 3 & $\mathrm{~B}$ \\
\hline $\boldsymbol{E}$ & Project Review \#1 & 1 & $\mathrm{C}, \mathrm{D}$ \\
\hline $\boldsymbol{F}$ & Conduct Market Analysis & 10 & $\mathrm{E}$ \\
\hline $\boldsymbol{G}$ & Conduct Technology Study & 7 & $\mathrm{E}$ \\
\hline $\boldsymbol{H}$ & Conduct Operations Analysis & 7 & $\mathrm{E}$ \\
\hline $\boldsymbol{I}$ & Conduct Legal Analysis & 5 & $\mathrm{E}$ \\
\hline $\boldsymbol{J}$ & Conduct Financial Analysis & 10 & $\mathrm{~F}, \mathrm{G}, \mathrm{H}, \mathrm{I}$ \\
\hline $\boldsymbol{K}$ & Develop Preliminary Business Plan & 10 & $\mathrm{~J}$ \\
\hline $\boldsymbol{L}$ & Project Review \#2 & 1 & $\mathrm{~K}$ \\
\hline $\boldsymbol{M}$ & Conduct Risk Analysis & 3 & $\mathrm{~L}$ \\
\hline
\end{tabular}


Table 2: Planning Information for Business Planning Project

\begin{tabular}{|c|l|c|c|}
\hline \multicolumn{5}{|c|}{ Table 2: Planning Information for Business Planning Project } \\
\hline Task ID & \multicolumn{1}{|c|}{ Task Description } & Duration (days) & Predecessor(s) \\
\hline $\boldsymbol{N}$ & Conduct Supplementary Analysis & 4 & $\mathrm{~L}$ \\
\hline $\boldsymbol{O}$ & Develop Final Business Plan & 10 & $\mathrm{M}, \mathrm{N}$ \\
\hline $\boldsymbol{P}$ & Prepare Oral Presentation & 5 & $\mathrm{O}$ \\
\hline $\boldsymbol{Q}$ & Submit Written Report & 2 & $\mathrm{O}$ \\
\hline $\boldsymbol{R}$ & Make Oral Presentations & 1 & $\mathrm{P}, \mathrm{Q}$ \\
\hline $\boldsymbol{S}$ & $\boldsymbol{F I N I S H}$ & 0 & $\mathrm{R}$ \\
\hline
\end{tabular}

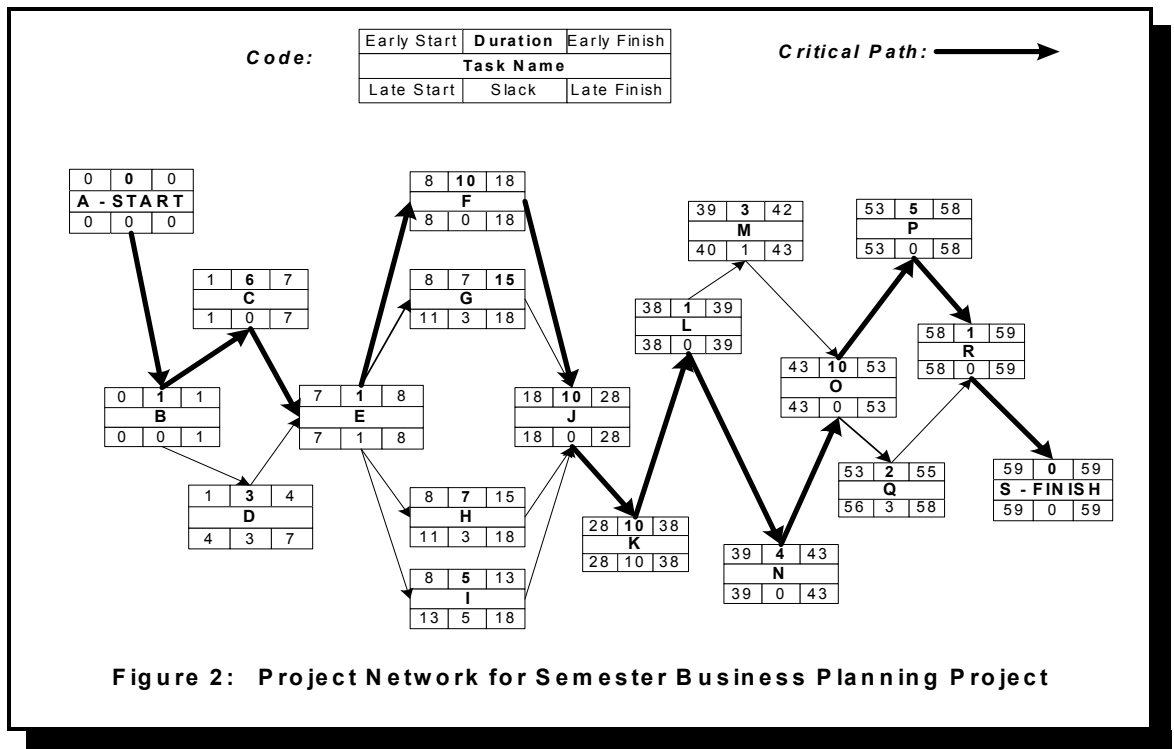

Figures 3 and 4 show the network diagram and Gantt Chart used in implementing the planning framework during the Fall 2003 semester using, in this case, the Microsoft Project project management software. Other faculty members seeking to use this approach will have access to a wide range of good project management software alternatives (Elliott, 2001). As seen in Figures 3 and 4 , the project milestones, assuming a start date of September $3^{\text {rd }}$, were:

\begin{tabular}{|l|l|}
\hline September 03: & Start \\
\hline September 12: & Project Review \#1 \\
\hline October 27: & Project Review \#2 \\
\hline November 17: & Submit Written Report \\
\hline November 24: & Oral Presentation \\
\hline
\end{tabular}


This approach gave the several student teams a road map to complete the project, provided a good basis for monitoring progress, and enabled timely faculty intervention to ensure timely completion of a quality business plan by each team.

Figure 3: Network Diagram for Business Planning Project using Microsoft Project- Fall 2003 Semester

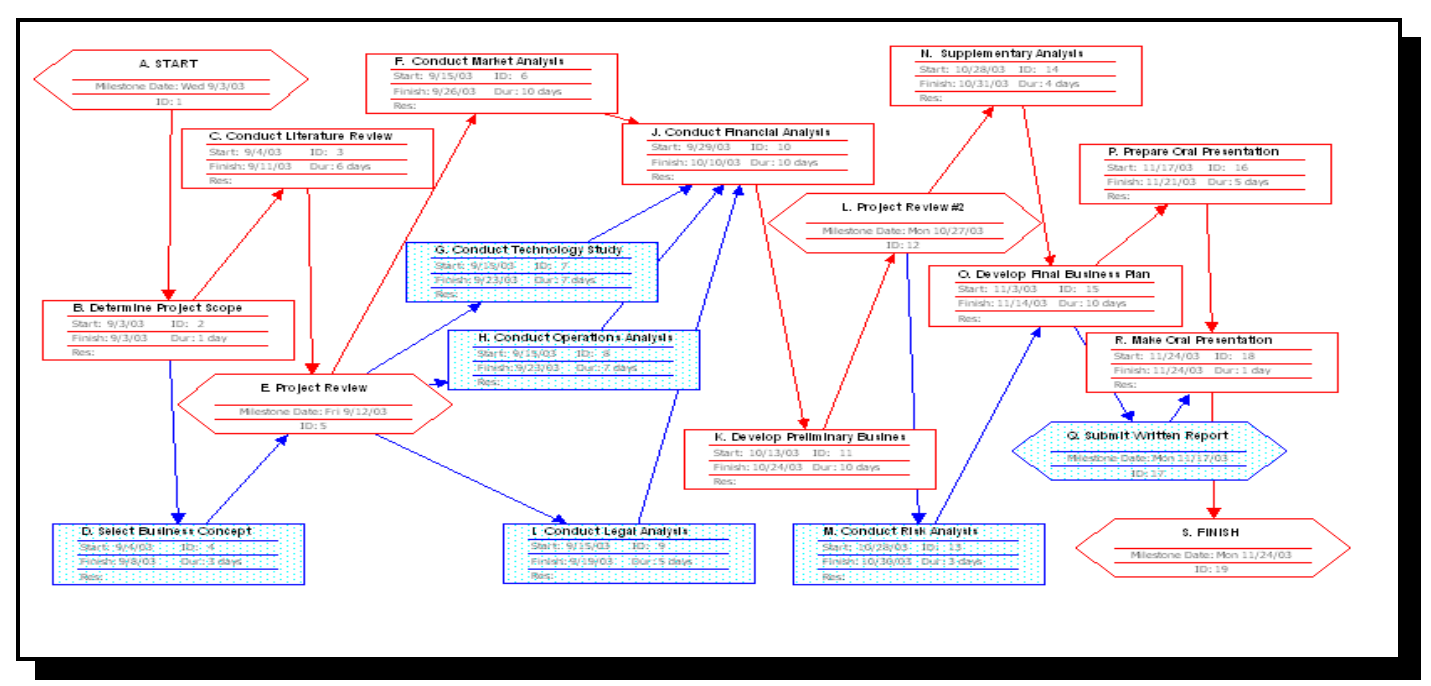

Figure 4: Gantt Chart for Business Planning Project using Microsoft Project - Fall

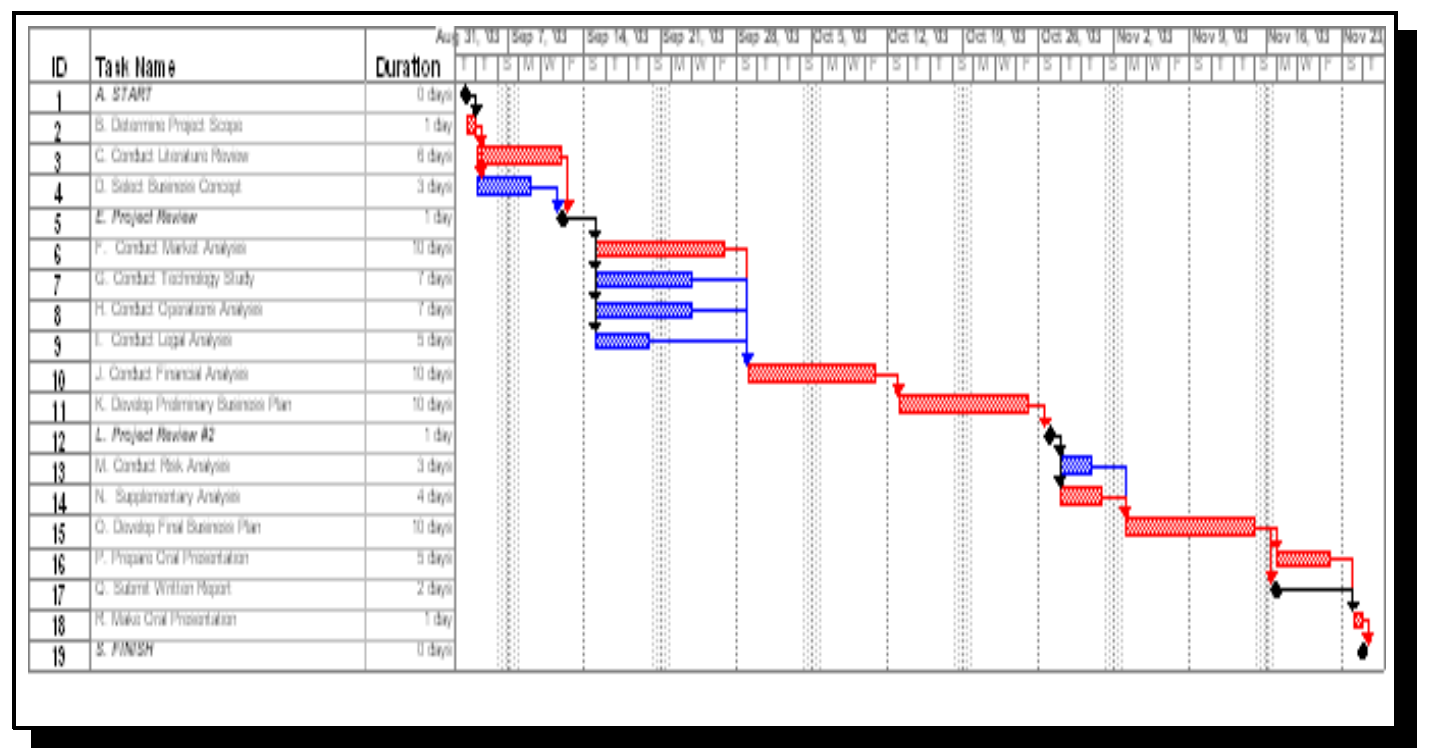

Journal of Entrepreneurship Education, Volume 9, 2006 
The business planning framework has also proven successful in guiding the efforts of student teams in developing technology-based business plans for several organizations and local companies to building upon successful technology commercialization studies. One of the business concepts was “The Village Online”, an Internet Service Provider (ISP) Development. This business plan described a proposal to acquire and turn around an under-performing local Internet Service Provider and launch The Village Online, a content-rich Internet Service Provider, to focus on providing an array of Internet-based services to university students and business consulting services to local businesses.

Another student team developed a business plan for BioMed Inc., a provider of home health care monitoring systems for infants. This business plan focused on the development and marketing of an ultra intelligent, vital signs - real wireless baby monitor to reduce the incidence of Sudden Infant Death Syndrome (SIDS), commonly called crib death. This biomedical system would enable the user to interpret readings of vital signs and heart rate when the monitor is in use and, as a preventive measure, track and notify guardians in the event of an emergency.

In both cases listed above, the planning framework assisted student teams in completing a quality business plan in a limited timeframe and securing several prizes in local, regional and international business plan competitions.

The business plan experience has also challenged and informed students at our School of Business and Industry who want to become real estate entrepreneurs. One team of MBA students developed a plan to establish Paradigm Management Inc., a new venture conceived to acquire and manage apartment communities. Paradigm would attract investors for the purchase of a 120-unit apartment community. The investors would have a priority claim on cash flow and the proceeds of a refinancing or sale. The entrepreneur would earn fees from putting together the purchase and financing, and from on-site property management. These fees would be predictable and large enough to cover the overhead of a startup enterprise. The process could be repeated periodically to build up ownership and fee income from a portfolio of apartment properties.

The student team used the planning framework to establish work assignments and set up a Gantt chart to guide implementation of the project. They identified crucial steps in the feasibility analysis and in setting up and operating the company. Guest speakers included bankers and investors with considerable experience in financing and operating apartment communities. An apartment field trip included an interview with the co-owner who found investors and also performed on-site management. Students were assigned case studies that are based on loan proposals submitted to an institutional lender's credit committee. They also had access to appraisal reports which functioned as "templates" for portions of their feasibility analysis. The planning framework helped the team stay focused and use their time efficiently. The plan they produced and the skills they developed can indeed be implemented in "the real world."

Journal of Entrepreneurship Education, Volume 9, 2006 


\section{DISCUSSION AND CONCLUSION}

The planning framework described in this paper has served as a powerful tool in managing business planning projects in academia. It has provided self-formed student teams with limited business experience a logical roadmap to guide their efforts in completing a business plan within a limited time frame. It outlines the logic behind a practical approach to business plan development which can be replicated in many environments. Indeed, we have successfully applied the approach when working with student teams to develop business plans for non-profit organizations. Implementation can be readily accomplished using any low-cost project management software tools and does not rely on the use of commercially available business planning software. It can be readily expanded to incorporate risk and uncertainty in the business planning process using EXCEL "addins” such as @Risk for Microsoft Project (Grossman, 2002). We envisage the continued use of this planning framework in managing business planning projects in academia.

\section{ACKNOWLEDGMENTS}

The authors would like thank the faculty and students in the five-year professional MBA program in the School of Business and Industry at Florida A \& M University for their support of the several business planning projects described in this paper.

\section{REFERENCES}

Benjamin, C.O., A. Freeman, K. Tucker \& G. Seay, (2001) "Managing Large Team Projects in Academia, Proceedings, International Conference on Computers \& Industrial Engineering (28 $8^{\text {th }}$ ICC\&IE) and the International Conference on Industry, Engineering, \& Management Systems (IEMS), Joint Meeting, Cocoa Beach, FL, Mar. 5-7, , p. 175-180.

Berry, Tim. Hurdle (1999) The Book on Business Planning: How to Develop and Implement a Successful Business Plan. Palo Alto Software, Inc.

Brown, Carolyn M. (2004), "Ford Motor Company is sponsoring the Ford BEST Business Plan contest in association with SCORE ‘Counselors to America's Small Business’ and Diversity Inc” Black Enterprise.

Cadenhead, Gary M. (2002), No Longer MOOT, Gary Cadenhead.

Cohen, William (1995), Model Business Plans for Product Businesses. New York: Wiley.

Cohen, William (1995), Model Business Plans for Services Businesses. New York: John Wiley \& Sons, 
Covello, Joseph A. \& Brian J. Hazelgren. (1994) The Complete Book of Business Plans: Simple Steps to Writing a Powerful Business Plan. Sourcebooks, Inc.

Eglash, Joanne, (2000) How to Write a .com Business Plan: The Internet Entrepreneur's Guide to Everything You Need to Know About Business Plans and Financing Options. McGraw-Hill Professional Book Group, Nov.

Elliott, Monica (2001), Buyer’s Guide Project Management, IIE Solutions, August, pp. 45-52.

Grossman, Thomas A. (2002), “Spreadsheet Add-Ins for OR/MS”, OR/MS Today, August 2002.

Gumpert, David A., (1997), “Creating a Successful Business Plan”, Chap. 5, pp. 120-147, in The Portable MBA in Entrepreneurship, $2^{\text {nd }}$ ed., William D. Bygrade (Ed.), John Wiley and Sons, New York.

Jones, Rebecca, (2000) “Business Plans: Roadmaps for Growth and Success”, Information Outlook.

Palisade Corp., (2003), @Risk for Project 4.0: Advanced Risk Analysis for Project Management

Promisel, Robert, (1999), Project Management Basics, IIE Solutions, March, pp. 39-47.

Sahlman, W.A. (1996), Some Thoughts on Business Plans, Harvard Business School Note \#9-897-101, Boston: HBS Publishing.

Seymour, Nicole, Business Plan Competitions: (2002), An Overview, May Digest, No. 02-01,CELCEE website, Retrieved Jul 30, 2004, Kaufmann Center for Entrepreneurial Leadership Clearinghouse on Entrepreneurship Education, http://www.celcee.edu

Yale University, New Ventures Non-Profit Competition (www.ventures.yale.edu), retrieved 6th August, 2004 


\title{
INNOVATION IN ENTREPRENEURSHIP EDUCATION
}

\author{
Debra A. Arvanites, Villanova University \\ James M. Glasgow, Villanova University \\ James W. Klingler, Villanova University \\ Stephen A. Stumpf, Villanova University
}

\begin{abstract}
There is an increasing need for innovation in business education to address and develop the characteristics and skills of those considering an entrepreneurial career. We describe two curriculum innovations taking place in a business school program that target the development of these characteristics and skills and overcome the weaknesses of traditional educational methods. Each of the innovations has incorporated experiential activities designed to stimulate entrepreneurship and strengthen the student learning process. One innovation involves a required management principles course designed to introduce sophomore students to intrapreneurship and the entrepreneurial spirit; the second is an elective set of courses which comprise an Entrepreneurship Minor for junior and senior level students. In developing each innovation, consideration and attention has been given to objections raised regarding traditional business education delivery.
\end{abstract}

\section{ENTREPRENEURSHIP AND INNOVATION IN BUSINESS EDUCATION}

Traditional programs (e.g., B.S. in Business Administration, MBA, Executive MBA) and methods (e.g., books, lectures, discussions, problem sets, case studies) will continue to be necessary, but not sufficient, to develop the characteristics and skills required to be successful in entrepreneurial activities. Innovative educational methods are needed to develop the entrepreneurial spirit and talents that are necessary to function effectively in an environment of strong market forces and complex people issues.

Entrepreneurship research has examined the key skills and personal characteristics of entrepreneurs (e.g., see Acs \& Audretsch, 2003; Davidsson, 2004; Kent, Sexton, \& Vesper, 1982; Stumpf, 1993). In comparison to non-entrepreneurs, entrepreneurs appear to be more creative and innovative. They tend to break the rules and do not need as much structure, support, or a formal organization to guide their thinking. They are able to see things differently and add value to a product, system, or idea that amounts to more than an adaptation or linear change. They are more willing to take personal and business risks, and do so in visible and salient ways. They are opportunity seekers - focusing on those problems that limit their success in reaching the vision. 
They are comfortable with failure, rebounding quickly to pursue another opportunity. They are often characterized by others as adventurous, ambitious, energetic, domineering, and self-confident. Entrepreneurs like to be in control and have autonomy in what they do.

Entrepreneurship frequently involves acts of creation and learning (Katz \& Shepherd, 2003; DeLuca, 2003). Joining a new venture means either being one of the creators, or working closely with them in a support role. It involves knowing how to focus on the most essential elements of the venture while continually taking inventory of the situation. One must perpetually promote the venture - its people, programs, and advantages relative to competitors. Maintaining a clear direction amidst hundreds of alternative choices is essential to the venture's success.Learning this is likely to require hands-on practice - doing, not just thinking about doing. This becomes apparent when one asks entrepreneurs why they choose to be one. Entrepreneurs often describe the benefits of their work in the following ways (Stumpf, 1993):

The work...

itself is what matters - creating something that is of value to the entrepreneur; can yield great financial and personal rewards - rewards that are distributed among those that contribute the most;

is often conducted in make-shift environments, with little protocol, formality, or imposed structure; demands that one lead, manage, and learn every day;

may, or may not, lead to market success - it is sufficiently satisfying to be a player even if one does not win the game;

is often varied, interesting and challenging, but can be repetitive, administrative, and clerical; provides great personal freedoms, but requires one to impose their own structure and discipline to get things done;

and, is more than a simple integration of known disciplines and theories - it involves many unique elements learned within the context of the venture.

For entrepreneurship education to be most useful, it must address, and develop in students, the skills necessary for success as an entrepreneur. Stumpf and Tymon (2001), along with DeLuca (2003) and others, identify various skills of entrepreneurial leadership:

\section{Visionary Leadership}

Share a vision of what the venture could become

Know who the key stakeholders are, and seek to give them enough of what they want to keep the venture solvent

Overcome setbacks by being resilient

Continue to champion innovative ideas when faced with substantial resistance

Build and sustain a risk-taking, opportunity-seeking climate

Live in the future and manage the present

Exhibit determination to succeed no matter what 


\section{Systemic Analysis}

Clearly understand the venture's competitive advantage and continually seek to enhance it

Leverage strengths in most endeavors pursued

Identify constraints - then quickly move to eliminate or avoid them

Find creative solutions to nagging problems

Negotiate well, getting more for the venture than would reasonably be expected

\section{Direction Setting Leadership}

Communicate in a concise, convincing manner

Establish priorities regarding which things need to be done, by when

Remain open to alternatives as new opportunities or threats are disclosed

Exhibit competence when dealing with ambiguous tasks

Cope with failure, stress, and rejection in a positive and productive manner

\section{Team Leadership}

Interact with many others, asking questions and stimulating them to contribute

Redefine issues to make them acceptable to others

Excite others to take actions - where they set their own direction

Traditional models of education fall short in their ability to link the knowledge and concepts "covered" in the classroom to the skills and practice of entrepreneurship. According to Nevins and Stumpf (1999, p. 6-7), "the traditional learning methods most commonly employed in management education provide learning experiences that are inadequate in several respects:

a. They fail to provide accurate, timely feedback on competency development in the areas most germane to success (a good metaphor that highlights the need for this is that of a professional trainer or coach in sports or acting).

b. They are insufficiently people- and time-sensitive (such as those experiences that are critical for many performance-oriented professions such as litigation and acting).

c. They need to create better practice fields (as in competitive sports) or practice sessions (as in music training) for skill development.

d. They should include life-like situations, including crises, for learning under pressure (such as state-ofthe-art flight simulators for pilots).

e. They must permit problem-finding and issue diagnosis as a central part of the experience (the learning method used in most professional service firms).

f. They should use master-apprentice relationships in the learning process (as done in dentistry and medicine as well as in craft trades) so as to guide an ongoing development process. 
g. They need to create mentor-protégé relationships to facilitate continuous learning beyond the formal educational process (witness such methods to develop mastery in sports occupations as well as the performing and visual arts).

h. They should threaten a trainee's ego and job security by placing them on the firing line to prosper or fail based on decisions and actions (consider survival training for the military or difficult developmental assignments for multinational executives)."

One might ask if these learning experiences are really necessary. Is it not possible for people to learn what they will need to know through reading, classroom discussion, computer-based instruction, and vicarious experiences? In many ways the education currently offered to business students does not suit itself well to the active and experiential learning styles and needs of adult learners (Stähli, 1992), and these traditional methods will be even less well-suited to the development of future entrepreneurs. Traditional learning methods have been criticized for failing to provide meaningful experience tied to building skills for future organizational productivity. Many of those criticisms identified by Nevins and Stumpf (1999) are addressed below for two innovative programs business programs that seek to develop the entrepreneurial spirit and talents of their students.

\section{OBJECTIVES OF INNOVATION IN BUSINESS EDUCATION}

To be successful, innovations in business education need to offer a valued, differentiated product to the targeted audience of prospective learners. New business courses and programs must reflect changes in the business environment (more digital, more global, more interdisciplinary, and less predictable) and the AACSB accreditation approach (mission driven, assessment of learning outcomes, and annual progress reports). After a review of the business school offerings and extensive conversations with several corporations supporting business education, Tymon and Stumpf (2003) determined that the most significant gaps in learning were too few opportunities for learners to:

- solve complex, cross-functional problems;

- make and implement judgmental decisions involving multiple, diverse stakeholders under conditions of risk and uncertainty (Jones, 1995);

- be entrepreneurial, including such skills as visioning, communicating, influencing, and negotiating (de Geus, 1997);

- and leverage technology and e-learning tools to meet business objectives.

\section{INNOVATION IN ENTREPRENEURSHIP EDUCATION：A CASE STUDY}

With these objectives in mind, the College of Commerce and Finance at Villanova University established a strategic plan requiring its faculty to develop innovative courses and programs. The College sets forth as the primary educational objective the creation of a learning environment the 
output of which are students who are "adaptive problem solvers" (defined in terms of "learning to learn" and achieving "life-long learning" skills). Stumpf et. al. (2002) describe the model as follows:

The learning environment created positions its primary stakeholder -- students -- at the center of a complex set of systems and interactions. The educational environment is affected by external forces including society, other stakeholders within the University, alumni, and businesses. The learning environment is seen as being shaped by accomplishing a set of specific educational objectives. Faculty is depicted in this model as learning facilitators, interfacing with external constituencies and internally guiding course and curriculum content. It is this mission that led the business school's leadership to realize that the preexisting functional approach to education will inhibit accomplishing the College's goals of facilitating international, interdisciplinary learning as a foundation for adaptive problem-solving. Internally, the College sees the educational environment as being shaped through the development of six skills and knowledge areas: technological competence, ethics and social responsibility, experiential learning, international perspectives, communication skills, and an integrated multidisciplinary curriculum. The business school has achieved significant progress in five of the six areas; the most challenging area yet to be mastered is the interdisciplinary nature of its course curricula and delivery structure. Based on Stumpf et. al. (2005), we present two case examples below of how the College enhanced student learning by integrating entrepreneurism into a required course (Management Essentials) and a new minor (an Entrepreneurship Minor of four courses). We conclude by identifying what we believe are the key success factors of these innovations.

\section{MANAGEMENT ESSENTIALS COURSE}

The Management Essentials course was modeled after courses being delivered at Bucknell University and at Oklahoma State University. The innovation of the Management Essentials course is to have an external panel of executives grade the final presentation. The external assessment has proved to benefit students.

Management Essentials is a required course for all sophomore business students. The course combines traditional pedagogical approaches (readings, lectures, class discussions, and testing) with a simulated management experience that requires application of theories and principles discussed in class to a practice field - the creation of a new product. Through this experiential project -- along with selected readings, lectures, and group discussions -- students develop insights about management theory, entrepreneurship, team development, dealing with uncertainty, decision making, problem resolution, and management practices. They have the opportunity to implement these learnings through the successful development of an organization that pitches a new product idea to corporate leaders. The stakeholders of the Management Essentials course are not only the students and faculty, but also the people and institutions (employers) that will ultimately come to 
depend on their knowledge and skills. The mission of the course is broad and ambitious, taking seriously an obligation to help prepare responsible leaders with an entrepreneurial spirit so that society can achieve results in an effective, efficient, and ethical manner.

The project deliverable is a product idea presentation to an executive panel that requires students to use information and techniques provided in their freshman year courses. Information and principles from sophomore level courses in accounting finance, and marketing, that some may be taking concurrently, or may have taken, helps them develop the rationale for their product idea. A significant objective of this cross-functional course is for the students to use what they have been exposed to, and to learn by doing as they venture into areas in which they have not necessarily received formal training simulating the work for pay environment.

Management Essentials challenges the students in four areas: functioning effectively and efficiently in a large group, becoming creative and entrepreneurial, developing independent problem solving skills, and effectively providing and using peer feedback. First, the size of the groups in which they work will number around twelve, as opposed to a more traditional four to six person group. The students do not choose the members of their group; they are determined by the faculty through a random selection process. Planning, communication, and controlling in a group of twelve members requires better processes than in smaller groups and the opportunity for social loafing is greater. Because the profile of students accepted at the College is one of high academic achievement and demonstrated leadership, there is the temptation to "do it myself" rather than collaborate in a group environment.

Classes are scheduled on M-W-F in blocks of two fifty minute periods, the time allotted to the traditional class occupies only half of that time. The second period is used for two purposes. First, students benefit from several two-hour lectures with Johnson \& Johnson and The Vanguard Group executives, which "bring to life" the information learned through the text, readings, and inclass discussions. The executive sessions focus on management challenges and approaches in the areas of Organizational Development, Strategy/Business Development, Operations, Finance, Marketing, and Ethical Leadership. On other days, the second period is used for the student "organizations" to work on their entrepreneurial ideas with their professor serving as a coach/consultant. To balance out the double class sessions used by the business executives the schedule includes "give back days' (i.e., no scheduled class that day) in a number equal to the extra sessions required by the extended classes.

A critical component of Management Essentials delivery is the close collaboration among faculty members and guest executive lecturers. All faculty delivering Management Essentials share a syllabus, schedule of topics, custom textbook, and support for experiential education. Faculty members meet frequently to discuss course delivery as well as the progress and challenges experienced by the student organizations.

Journal of Entrepreneurship Education, Volume 9, 2006 
Through its cross-functional, time-flexible, feedback rich structure, Management Essentials is innovative. Many of the criticisms of traditional courses discussed in Section 1, Why Innovate in Business Education, and Section 2, Objectives of Innovation, are addressed through this course.

\section{EXPERIENTIAL LEARNING BENEFITS IN MANAGEMENT ESSENTIALS}

In most courses students do not have the benefit of receiving significant structured feedback from their peers based on how others observed and perceived their performance and contributions. Giving, receiving, and then using constructive feedback are skills that must be developed to be successful in business, and more so to be a successful entrepreneur. The course requires the student organizations to create evaluation criteria for three areas of importance: performance, motivation, and teamwork. Three feedback sessions are provided during the semester; the feedback format consists of a numerical rating and commentary on each of the values. The evaluations are anonymous providing for greater candor, and each student sees only their own; the professor also sees the evaluations in three iterations, the detail by student (what the student sees), the composite for the organization, and the input by each student. The evaluations serve as a confirmation of positive behaviors and provide a "wake up call" for students who are underperforming. How to provide effective feedback and then use it is a learning process that the faculty address as the semester progresses.

The student receives frequent feedback from additional sources during the semester. Four knowledge-focused tests are given to ensure the student understands the core concepts and facts conveyed in the text, through class discussion, and presentations by the corporate executives. That feedback aligns with a classic "teach and quiz" methodology and is the standard feedback that a student might expect.

The professors for this course serve in multiple capacities including chairperson for the organizations, coach, and consultant. Professors have multiple opportunities to provide feedback to the students as individuals and within their organizations. The role of the consultant is fulfilled by helping the organization develop effective processes and procedures, not by telling but by influencing the choices made and demonstrating methods for generating ideas, exploring options, making decisions, and resolving issues. The professor as coach works with the leadership on an individual basis to provide a sounding board and counsel. At the conclusion of the semester, each organization presents their product plan to executives of Johnson \& Johnson and The Vanguard Group. The executives challenge the logic and rationale behind the product ideas and provide feedback on their viability. All rights to the product concepts developed by the students' of Management Essentials are retained by them.

Management is often described as the effective and efficient use of resources to obtain organizational objectives, with and through other people. Being people and time sensitive is essential. The students enrolled in Management Essentials discover what this means as they must 
organize themselves, plan their activities, and control their progress in order to complete the project on time with quality. While the schedule for the classes identifies the flow of the course and the dates when deliverables are due, it is the students' prerogative, if not the tendency of many, to put off getting started. Early in the semester deliverables such as identification of leadership, written position descriptions, organizational structure, agreed to norms, and a mission statement are required of the organization. The curriculum of the class parallels the development of the students' organization. It commences with discussions on group development, entrepreneurship, organizational design, roles and functions of management, and performance appraisal. The first executive session discusses how the company addresses the human resource issues the student organization is facing.

In creating an organization and in developing a product idea after researching potential ideas, the students in Management Essentials operate as manager/leaders in an environment that views management missteps and errors as learning opportunities. They have a practice field on which to examine their skills in inventing and proposing a new product. The managerial and entrepreneurial skills that are practiced in the context of the class are often transferred to other classes and club experiences. The practice field begun with Management Essentials clearly expands the skill building opportunities for students in their other activities.

The course is fast paced and requires, as does business, that its members are able to simultaneously address multiple deliverables. It simulates life-like situations. They are required to segment tasks, delegate, build trusting relationships, motivate one another, and audit their progress. The lessons learned through a simulation reinforce what is discussed in the formal class sessions and provide a feedback-rich experience for the students, one they will remember long after they forget the specifics of Maslow's hierarchy or the five stages of group development. Strongly contributing to the realism of the situation is the active participation of the Johnson \& Johnson and The Vanguard Group executives through the semester and at the final presentation. The experience of responding to the questions posed by the executive panel at the final presentation contributes to building the skill of "thinking on your feet" and defending one's assumptions.

Reason would suggest that in order to develop skills as an adaptive problem solver one is placed in a situation that is unfamiliar and requires changes take place in processes or approach. Certainly, Management Essentials meets these criteria. It permits problem finding and issue diagnosis as a required part of the course. The student organizations tend to create structures that are segmented by function such as executive, accounting, marketing, and research. The flow of the tasks to be completed and the available talent within each organization tends to require multi-tasking and often places students in departments whose function is a concurrent area of academic study. For example, a student may be enrolled in Principles of Marketing and be the V.P. of Marketing for their organization before completing the Principles of Marketing course. The interdependency of the departments and the individuals becomes evident and the students learn to better organize, plan, communicate, and control their activities.

Journal of Entrepreneurship Education, Volume 9, 2006 
Learning how to research issues and opportunities is central to the success of the project so the students are shown how to use the extensive database of Villanova's business library. The business librarian presents a class on how to use the library's on-line and reference resources. He meets with student organizations to provide counsel on addressing research obstacles as they are encountered. The product the organization is charged with developing is a consumer-packaged good that will fit into the scope of the product lines offered by Johnson \& Johnson. That sector was chosen because the students are more familiar with categories such as oral hygiene, skin protection, baby care, etc., than they are with financial or industrial product categories. Still, there is little they know, and therefore need to learn, about the financial structure and marketing needs of those sectors.

The role of the professor as coach enhances the faculty-student relationship and provides an opportunity to help the students navigate the organizational and operational waters that are somewhat uncharted. The relationship becomes more like that of a master-apprentice than teacherstudent. The student leaders in each organization encounter multiple challenges, the solutions to which are not found in the text, the library, or on the Internet. The coach relationship allows the student to tap into the professor's experiences and to have the professor mentor them through the process of resolving difficult issues such as non-contributing members, interpersonal conflict, groupthink, and escalation of commitment to an idea or strategy that appears to be failing. It is through encounters that deal with real-time issues that the student is guided to develop their thought processes to not only address the issue but to create within themselves the ability to use that process as the basis for addressing similar issues in the future.

From the first day of class, students are aware that they will be accountable to and graded by their professors and a panel of executives from Johnson \& Johnson and The Vanguard Group. They will be on the firing line for some course deliverables. Members of the organizations partnering with the Management Essentials serve as the panel to hear the students' product proposals. The panel listens and provides feedback to the students and the faculty regarding the students' performance.

\section{MANAGEMENT ESSENTIALS INFLUENCE ON ESTABLISHING AND REINFORCING ENTREPRENEURIAL SKILLS AND SPIRIT}

Earlier we discussed the various skills that have been identified as essential for success as an entrepreneur. To determine how Management Essentials might affect the development of those skills we surveyed 1551 students who successfully completed the course since its inception in January of 2003. We received 124 responses (8\%). Three questions were asked; the first was closed

- ended, yes or no, the other two were open-ended that required a qualitative response. Have they been or are they involved in the start-up, or continuation of a small business, an enterprise that is entrepreneurial? Twenty nine (23\%) of the respondents replied that they were involved; many stated that Management Essentials had a positive influence on their interest in entrepreneurship. 
While Management Essentials is not designed to develop entrepreneurs, its focus on self-managed teams, adaptive problem solving, and operating in an uncertain environment are all conducive to the development of entrepreneurial skills.

What influence did their experience in Management Essentials have on their choice of major or career? Management Essentials had a positive influence on the choice of major. In some cases it confirmed why they were interested in a certain discipline while in others the exposure facilitated a change in focus or the interest in double majoring. Effective with the 2003-04 academic year, Management Essentials was required of all sophomore students in the College of Commerce and Finance; that is the year in which they choose their major. Prior to 2003 the course was taken in the junior or senior year, after the student chose their major. The course now requires sophomore students to delve into management, marketing, and finance functions, often before their major in chosen. One benefit of the course is that it exposes the students to how those disciplines interrelate in a business environment, thereby providing them with additional rationale for selecting their major area of study.

What was the major learning they took from Management Essentials? Specifically, we looked for responses that indicated the respondents took from the course insights and abilities directly related to the skills identified by Stumpf and Tymon (2001), among others, as necessary for success as an entrepreneur. The students provided specific comments that supported their development of the following essential entrepreneurial skills.

Systemic Analysis: Twenty (16\%) of the respondents cited the development of their ability to leverage the different and sometimes competing strengths within the organizations, to identify competitive advantages and build on those strengths, to think creatively, and to effectively solve problems.

Direction Setting Leadership: Thirty-eight (31\%) of the respondents stated they enhanced their knowledge of how to communicate more effectively, to listen more effectively, and to frame arguments in a manner that provided clear explanation and persuasion. They cited their improved ability to manage uncertainty and ambiguity; to develop plans and to make adjustments to the plan, or its execution.

Team Leadership: Sixteen (13\%) of the students all participated in teams and they selected their leadership, not all of the students have the opportunity to hold leadership positions. The students reported on their improved ability to ensure that all in the organization were heard and to encourage feedback. One cited learning the importance of establishing an environment of candor, preparedness, and Trust as systemic characteristics of the organization. Others reported learning not only how to lead a team but how to act, to contribute effectively in a team environment.

The construct of the Management Essentials curriculum provides students with an environment that integrates theory with practice, and provides exposure to multiple disciplines of Management, Marketing, and Accounting. An important and intended benefit is that it teaches the 
life-lessons of the importance of effective planning, communication, managing in a state of uncertainty and working effectively and efficiently with others.

\section{AN ENTREPRENEURSHIP MINOR}

In designing the minor in entrepreneurship there were three goals. First, the minor was to be intense and pressure packed, mirroring the world of an entrepreneur starting a venture. Second, even though it was to require four courses of three credits each, it was to be fully integrated, as is the world of the entrepreneur. Finally, and most critical, in addition to talking about entrepreneurship, the students would have to be involved in entrepreneurship - doing it, and being evaluated on this performance.

The Entrepreneurship Minor is available to all business majors with junior or senior standing. By the end of sophomore year students at Villanova have completed the basic courses in each business discipline. The Entrepreneurship Minor is designed to build on this base of knowledge and experience. All courses in the minor must be taken in the same semester. This presents scheduling difficulties for some students and may reduce the number of students in the minor, but is necessary to provide the continuity and intensity needed to simulate the world of the entrepreneur.

The minor has three courses with lecture, discussion, use of multi-media, and testing, and one course, called a practicum, that is entirely dedicated to starting a venture during the semester. The scheduling of the courses uses a 50-minute, M-W-F format, with the three courses back-to-back in the same room from 9:30 am until 12:20 pm. The faculty moves, not the students. This block of classes affords the luxury of occasionally using the three hour block for guest speakers. The practicum is also 50 minutes in length and meets on a M-W-F schedule in the afternoon.

The three courses are: Entrepreneurial Management and Leadership, Entrepreneurial Marketing, and Entrepreneurial Finance and Accounting. Each has been designed to follow a similar structure emphasizing idea generation, opportunity recognition, startup planning, team building, launch, growth, and harvest. The entire range of entrepreneurial activity is covered in the minor - with certain issues (e.g., legal forms of business, writing a business plan, market research, staffing) covered primarily in one of the courses. While each course has separate texts, all are based on a model of the entrepreneurial process from one text (Timmons and Spinelli, $6^{\text {th }}$ ed., 2004). In addition, common cases, movies, videos and readings are addressed in all three courses. Finally, the deliverables for the courses are integrated so that the final business plan and venture evaluation is read and graded by the faculty from each of the courses in addition to the unique deliverables required in each course.

The fourth course is a hands-on experience. In teams of from 5 to 10 they must conceive, operationalize, start, end, and evaluate a venture within the confines of the 14 week term. Examples of venture projects are t-shirt sales, bus trips, sales of embroidered bags, after-hours food services, unique games appealing to the university community, and events (e.g., concert, golf tournament). 
Other than the students' imaginations, the only limitations to the ventures are that they must end within the semester, be legal, and be consistent with the values and mission of the University. Teams must make formal presentations to a panel of outside bankers, angel investors, and venture capitalists to receive seed money (provided by the university), which is limited to $\$ 2,500$ per venture. This seed money is given interest free and must be paid back by each venture team. All profits from the ventures are donated to a charity chosen by the students.

The staffing of the minor emphasizes practitioners -- full-time and adjunct faculty with significant entrepreneurial experience. As the minor enrollment increases, maintaining this experienced teaching core will be an important issue. Team teaching - matching an academic with a practitioner - has proven to be an effective model. Faculty members are in touch constantly - and often attend the sessions taught by their colleagues. This helps them maintain continuity and emphasizes to the students the integrated nature of entrepreneurship.

\section{EXPERIENTIAL LEARNING BENEFITS IN THE ENTREPRENEURSHIP MINOR}

Throughout the duration of the Entrepreneurship Minor the three traditional courses are infused with the experiences of the students in the practicum. As the student teams address issues in their ventures, the faculty comment and discuss the techniques being used and provide feedback and coaching. By catching students doing entrepreneurship, it is possible to provide accurate and timely feedback on their skills and ideas. For example, each team must do market research as a means of proving that there is a market for its proposed product or service. The faculty in the practicum as well as the marketing course faculty comment on the design of the survey instruments, the data gathering techniques, the data analysis, and the reliability and validity of the results.

The pressure of the practicum's requirement to start and end a venture within the confines of the semester imposes significant time sensitivity - bordering on panic as the semester progresses. The use of mid-sized groups requires each student to develop sensitivity to other students in order to launch and run a new venture. Time management and the effective delegation and assignment

of tasks become essential. Teamwork, and the requirement that people become knowledgeable about their own as well as others strengths and weaknesses, greatly enhances student "people sensitivity". Throughout the semester the students participate in team building activities, including a ropes course. Much of the entire minor and practicum is based on doing, not talking about, entrepreneurship.

Every effort is made to have the experience be life-like, within the constraints of the requirements for testing and the time limit of a semester. The students must pitch their opportunity to knowledgeable outside experts in order to receive funding, and these same outside experts attend the final presentation of their venture experience. As in the Management Essentials situation, the presence of outsiders in an evaluative role transforms the experience from a traditional academic one into one that minors the pressures and activities of the workplace. Students identify the success 
factors of their ventures and deal with them on their own. If the venture requires the use of written logos, or the scheduling of facilities, the students must identify the person to talk to, make the call, and negotiate in a way to get what they need. The faculty role, often reiterated to the students, is to observe -- permitting the students to find their way, even though a more efficient or effective way may be known to a faculty member. There is direct faculty intervention when the students are making such a great error that their venture or they are endangered. This is a rare event.

Since all of the students in the minor are upper level (junior and senior), they have developed significant skills in using data bases and Internet/library resources. The hands-on aspect of the practicum challenges them as individuals and as teams to become systematic and deliberate in their problem identification and diagnosis activities. The faculty coaching role, noted above, is substantially dedicated to these processes.

In the Entrepreneurship Minor learning at the elbow of a practiced master is a common model for learning but is difficult to do in a classroom setting, partly because of the nature of classrooms as well as the expectations of students based on their previous classroom experiences. An attempt to create this type of situation is achieved through the use of practicing entrepreneurs as faculty. In a sense, the students are learning from the experiences of the entrepreneurs in the classroom, as well as through being coached by "masters".

In addition to providing mentor-protégée relationship opportunities with the faculty, numerous guest speakers are introduced to the students throughout the semester with the expressed understanding that students may interact with them via telephone or email after the class. Students have availed themselves of this invitation and found it worthwhile.

From the first moments in class the students understand that they will be given the autonomy to prosper or fail, within the caveat noted above that we will pull them back from a catastrophic mistake (we call it falling off the cliff). They are on a firing line from day one. One of the ways this becomes tangible is that after the first 4 weeks, the running of the practicum is $100 \%$ in the hands of the students.

With only a minimum of structure provided (they must all attend, and each session opens with each team giving a 2-3 minute status report to the other teams), they are on their own. At first it is difficult, disorganized and inefficient, but as deadlines become real, and outsiders are coming to hear their presentations, they shape up quickly.

\section{KEY SUCCESS FACTORS THAT HELP TO CLOSE LEARNING GAPS}

Several business school learning gaps previously identified by Tymon and Stumpf (2003), DeLuca (2003), Jones (1995), and de Geus, (1977) are being addressed as Management Essentials and the Entrepreneurship Minor evolve. As described above, students have a complex task requiring a cross functional solution; students are involved with judgmental decision making involving multiple diverse stakeholders under uncertainty; the very nature of the work required forces students 
to be entrepreneurial; and technology is incorporated as students create a web site for their product idea and presentation/communication of it. As a result of these two innovations in entrepreneurship education, the authors have learned that:

\footnotetext{
Students can cope effectively with experiential learning environments that are challenging, perceived to be highly ambiguous, and that demand that they work in self-lead 'organizations' for long hours outside the classroom and beyond traditional homework assignments;
}

The professor's ability to affect learning is significantly enhanced when his/her role is expanded beyond that of an expert deliverer and evaluator of knowledge to include the roles of coach, counselor, and consultant;

Learning is enhanced through multiple learning stimuli and opportunities that enable the student to hear and experience information and ideas from multiple sources (text, lecture, guest speakers, professor, class peers, and business librarian);

And course delivery and perceived quality of learning is enhanced by active and ongoing collaboration among those teaching an experiential, cross-functional, innovative course.

Cross functional entrepreneurship education requires information sharing. The syllabus and exercises for Management Essentials and the courses in the Entrepreneurship Minor are shared with other College departments (finance, accounting, and marketing) so that the faculty in those departments will know what is expected of the students and the resources that are provided. The added communication among academic departments accelerates the integration of learning. Where students may not have experienced course integration until their final capstone course, typically business strategy, they now have an opportunity to recognize the connectedness of their courses as they work through their years of advanced business study.

\section{AUTHORS' NOTE}

The authors are listed alphabetically. To be published in the Journal of Entrepreneurship Education 2006.

\section{REFERENCES}

Acs, Z. J., \& D. B. Audrestch (Eds.) (2003). Handbook of entrepreneurial research. London: Kluwer Academic Publishers

Davidsson, P. (2004). Researching entrepreneurship. Boston: Springer Science \& Business Media

de Geus, A. (1997). The living company. Boston, MA: Harvard Business School Press.

Journal of Entrepreneurship Education, Volume 9, 2006 
DeLuca, J. R. (2003). Entrepreneurial leadership: Building capacity for speed, risk, and continuous learning. In M. Goldsmith, V. Govindarajan, B. Kaye, \& A. A. Vicere (eds.), The many facets of leadership. Upper Saddle River, NJ: Pearson Education, pp. 99-114.

Jones, T. (1995). Instrumental stakeholder theory: A synthesis of ethics and economics. Academy of Management Review, 20(2), 404-437.

Katz, J. \& D. Shepherd (Eds.) (2003). Advances in entrepreneurship, firm emergence, and growth. Vol. 6, London: JAI

Kent, C. A., D. H. Sexton, \& K. H. Vesper (Eds.) (1982). Encyclopedia of entrepreneurship. Englewood Cliffs, NJ: Prentice-Hall

Nevins, M. \& S. A. Stumpf (1999). 21 st -Century leadership: Redefining management education. Strategy \& Business, Issue 16, $3^{\text {rd }}$ Quarter, 41-51.

Stähli, A. (1992). Harvard Anti Case. Management-andragogik. Bd.1, London: GSBA Zurich

Stumpf, S. A. (1993). The growth challenge: How to build your business profitably. Chicago: Dearborn Publishing Group

Stumpf, S. A., D. Arvanites, J. Glasgow and J. Klingler (2005). Success factors for innovation in business education. In R. Berndt (ed.), Erfolgsfaktor innovation. Berlin, Germany: Springer-Verlag, pp. 353-364.

Stumpf, S. A., D. Stout, M. Najdawi, T. Monahan, V. McWilliams and R. Blanchard (2002). International, interdisciplinary management education and development: Can business schools deliver? In R. Berndt (ed.), Management Concepts for the New Economy. Berlin, Germany: Springer-Verlag, pp. 59-80.

Stumpf, S. A. \& W. Tymon (2001). Consultant or entrepreneur? Demystifying the "war for talent". Career Development International, 6(1), 48-55.

Timmons, J. \& S. Spinelli (2004). New venture creation, entrepreneurship for the $21^{\text {st }}$ Century. $6^{\text {th }}$. Edition, NY: McGraw-Hill/Irwin

Tymon, W. and S. A. Stumpf (2003). Developing leaders in difficult times: A need for interdisciplinary learning in the MBA. In R. Berndt (ed.), Leadership in turbulenten zeiten. Berlin, Germany: Springer-Verlag, pp. 37-53.

Villanova University Catalog (2004). Undergraduate Studies 2004-200

Journal of Entrepreneurship Education, Volume 9, 2006 


\title{
A $21^{\text {st }}$ CENTURY MODEL OF ENTREPRENEURSHIP EDUCATION: OVERCOMING TRADITIONAL BARRIERS TO LEARNING
}

\author{
Brooke R. Envick, St. Mary's University \\ Prasad Padmanabhan, St. Mary's University
}

\begin{abstract}
This paper introduces scholars in the discipline of entrepreneurship to a $21^{\text {st }}$ century model of delivering interdisciplinary entrepreneurship education. The basic premise behind the model truly differentiates it from common entrepreneurship programs, which is the capability to overcome five traditional barriers to learning: isolation, time, limited expertise, cost, and rapid globalization. Readers are provided the essence and effective of the program, and are invited to learn more about it and consider its adoption at their own universities.
\end{abstract}

\section{INTRODUCTION}

This paper introduces a model that describes a new approach to entrepreneurship education, which eliminates common barriers to learning and exposes students to the realities of entrepreneurial uncertainty and ambiguity. The program described offers many different benefits relative to traditional educational models. The uniqueness of the program is that it allows students the flexibility of tailoring their own goals to the learning environment. There is also a carefully selected blend of traditional classroom content and off-campus activities. In addition, the model affords students the opportunity to test out the soundness of their business plans in relatively risk-free domestic and international environments.

\section{LITERATURE REVIEW}

Since 2000, there has been a tremendous proliferation of entrepreneurial programs and courses in the college and business school curricula (Osborne, 2000). This has been triggered in part by the recognition that small businesses create the majority of new jobs in the country (Nunn \& Ehlen 2001), and by a need for colleges and universities to differentiate their product offerings in order to attract students due to increased competition. Unfortunately, undergraduate education is still too compartmentalized into rigidly defined disciplines. As a result, students do not get the required exposure in academia to adequately function in the real world (Smith, Hornsby, \& Kite 2000). Although disciplined based teaching can improve the analytical skills of students (Borg \& Borg 
2001), they cannot easily impart the tools necessary for the students to deal with uncertainty in an environment characterized by globalization and rapid change.

Entrepreneurship, by definition, is an area of study that is centered on dealing with ambiguity, uncertainty, and complexity. Emmett (1999), Glennon (1966), Begley \& Boyd (1987) and Lambing \& Kuehl (2000), among others, document evidence that entrepreneurs tolerate uncertainty and ambiguity better than others. Likewise, Shane and Venkataramanan (2000) suggest that entrepreneurial ventures are started by individuals with a high degree of tolerance for ambiguity. Hence, it seems important that entrepreneurship courses should make attempts to educate students on how to deal with these issues. In a recent paper Envick, Madison \& Priesmeyer (2003) present a cross-course project model that employs the contents of one course to help teach the learning objectives of another course in an effort to remedy the deficiencies of traditional courses, and by creating situations where students are forced to deal with uncertainty and ambiguity. Unfortunately, this model is still limited by the structured environment of a traditional classroom setting. Furthermore, the cross course project model embraces students who are predominantly securing a business degree. In real life, entrepreneurs come from a variety of disciplines and are forced to deal with all kinds of uncertainties such as globalization.

Today, globalization forces are stronger than ever. The world is witnessing global competition for markets and jobs from countries like India and China. If anything, the level of ambiguity, uncertainty and risk has increased over the last decade. It has been suggested that countries need to innovate to stay ahead of competition (Madison and Padmanabhan (2004, 2005), The Economist, Editorial, October 5, 2005). Since entrepreneurs create most of the new jobs, there is an urgent need on the part of universities to offer courses that teach these skills, bearing in mind the global nature of competition.

To attempt in part to remedy these problems, the authors developed an interdisciplinary entrepreneurship certificate program to offer students in addition to their major. This paper describes the basic elements of this model as it has been operationalized at our university. It is important to note that two other universities have employed similar models, and the three universities are working in collaboration to make this model one of national and international prominence.

\section{THE $21^{\text {ST }}$ CENTURY MODEL OF ENTREPRENEURSHIP EDUCATION}

The model presented has actually been in existence for over six years at one university, and it has been highly successful. Subsequently, several representatives from two other universities were invited to a workshop to learn the model and discuss ways to implement similar programs at their respective universities. Both universities have since put this program into action and have achieved similar success. 
The 21 st century model of entrepreneurship education offers many different benefits relative to traditional educational models. The uniqueness of the program is that it allows students the flexibility to tailor their own learning by balancing the amount of traditional classroom learning with off-campus opportunities, including domestic and international business trips.

The model is a university wide program designed for all students regardless of major. At our university the program has included students from a variety of fields including accounting, industrial engineering, English communication arts, electrical engineering, entrepreneurship, biochemistry, psychology, and international relations. The goal of the program is to provide students with the self-confidence, knowledge, experience, and skills necessary to initiate their own business ventures. Participants in the program complete a yearlong series of activities, which include two three-hour classroom courses, a domestic business trip, an international business trip, networking opportunities with local business leaders, invitations to local business workshops and seminars, and an optional apprenticeship. They are also required to participate in a service learning activity that employs their newly acquired entrepreneurial knowledge and skills. This $21^{\text {st }}$ century model of entrepreneurship education provides students with experiences unlike any other program, because it is designed to overcome five traditional barriers to learning: isolation, time, limited expertise, cost, and rapid globalization.

Isolation: A traditional classroom setting isolates students from other useful learning environments such as speaking engagements in the local business community where successful entrepreneurs share their stories. Other useful activities are workshops and seminars hosted by Chambers of Commerce at different locations throughout the community. Taking fieldtrips to entrepreneurial businesses is another beneficial activity, where a student can learn wonderful lessons. Attending national conferences, such as the one hosted by the Collegiate Entrepreneurs' Organization, is another avenue for acquiring knowledge. These are just a few examples of extremely beneficial opportunities available to students outside of the classroom.

Time: The amount of time provided during a regular semester can be a deterrent when trying to teach a comprehensive knowledgebase such as entrepreneurship. That is why a certificate program that spans over the course of one year is more appropriate. It bridges the two semesters together nicely, and even offers students summer activities beyond the spring semester. This time frame allows for more depth and breadth in the learning opportunities made available to students. Spring break is utilized for the international business trip, which allows for a full extra week during the regular semester for learning and business plan development. Oftentimes, students are able to count the courses offered in this certificate program as electives in their respective majors.

Limited Expertise: While many of us may not like to admit it, professors do have limitations on their expertise, even within our own field. In a traditional semester-long class, students only have access to the knowledge and experiences of the professor teaching the course. This model recognizes that there are different road maps to success, especially in other environments. When students hear advice and success stories from entrepreneurs, investors, and other business 
executives, they realize there are multiple ways to succeed, which is the true recognition and acceptance of lifelong learning.

Cost: The cost of attaining significantly more education about a discipline is generally too great when other learning environments, besides the classroom, are incorporated into the students' education. To overcome this barrier, our model seeks sponsorships from individuals and businesses in the community. The sponsorship fund allows students to take business trips and attend events that require registration fees. All learning materials such as textbooks, case studies, and software are also covered by program funds. It is important to note that students also pay an additional program fee beyond their regular tuition to be a part of this selective program. However, because of the sponsorship fund, the tangible benefits far outweigh the cost of their program fee, and they quickly realize the value of the intangible benefits on top of that.

Rapid globalization: The advent of new global players (especially China and India) increases the degree of uncertainty, but also adds new opportunities. The $21^{\text {st }}$ century model presented here allows students to be exposed to these environments by taking an international business trip. The main purpose of this trip is to develop local business contacts. It is designed to get students out of their comfort zone and test out their ideas for a business venture in a relatively risk-free international environment. They also became fundamentally aware of international cultures and economies.

Prior to the international business trip, students spend time preparing a business plan. Depending on their plans, they are either selling or buying products in the country of interest. They develop a list of questions related to these focal points, and at the same time assimilate knowledge about that country's entrepreneurial culture. Students analyze their business concepts and address questions related to the purchase their products/services, how they would protect intellectual property, and what modifications would have to be made to the product/service to make it work in another country. They also determine what kinds of negotiation skills are necessary. Answering these questions and experiencing their own successes and failures will serve them very well after graduation. Because students must develop their own business plans, it forces them to behave and ask the same types of questions as real entrepreneurs would in the same setting.

\section{EFFECTIVENESS AND BENEFITS OF THE PROGRAM}

We are finishing out the second year of the program at our university. The number of applications for the second year more than doubled that of first-year applications and included more representation from students outside of the School of Business.

As mentioned, the total value for the students is well beyond their program fee, when the cost

of two business trips (domestic and international), learning materials, and conference/workshop/seminar fees are included. And this does not include the intangible benefits such as developing a professional network, gaining real world experiences on business trips, as well as the means to realistically initiate a new venture by the end of the program.

Journal of Entrepreneurship Education, Volume 9, 2006 
When students were asked to anonymously provide feedback about their experiences in the program, they all responded quite favorably. Some of their comments are as follows:

1. "This program has opened my eyes to a new world and has related my degree to the business world."

2. "The books we received in the program furthered our knowledge about entrepreneurs and helped formulate our own ideas."

3. "The trips allowed us to experience business while we were out of our comfort zone."

4. "Participating in the program and meeting successful entrepreneurs solidified why I want to be a part of the program and why it is such an essential part of our business community."

5. "The international business trip was worth 100 hours in the classroom."

The professors involved in the program also notice dramatic changes in the students from the time they enter the program until they complete all the requirements. The non-business majors, in particular, enter the first class slightly intimidated and unsure of what they can contribute. By the middle of that semester, they realize they have just as much to contribute as the business majors. The synergy created among students from a variety of majors is unique and rewarding. Another observation is the huge boost in their confidence levels after they return from business trips. They come to realize that they can conduct business anywhere in the world, and it truly provides them a level of self-assurance they simply would not acquire in a traditional classroom setting.

Entrepreneurship occurs in every department across all universities. This program allows these entrepreneurial endeavors to come to fruition and publicly recognizes them across campus and in the business community. By offering a certificate of achievement, this program allows any student from any major to participate, which not only strengthens and develops individual students but the entire field of entrepreneurship.

\section{LEARNING MORE ABOUT THE $21^{\text {ST }}$ CENTURY MODEL OF ENTREPRENEURSHIP EDUCATION}

The purpose of this paper was to introduce scholars involved in entrepreneurship education to a new program model that has achieved great success at three pilot universities. This success has been well documented for over six years at one university and two years at the other universities. It is important to note that this is not a cookie-cutter approach. The three universities that currently run the program have slightly different methods of delivery that fit the size, mission, and available resources at their universities. However, there are some core values that remain consistent across all three sites. The universities involved also collaborate with each other, both professors and 
students. The professors collaborate to maintain the core values and offer each other suggestions and ideas. The students have conducted joint business trips and have also competed with each other in an elevator pitch competition. The programs at the three universities could be considered one dynamic learning community with room to grow.

Workshops are available each summer to train new universities on how to successfully implement the program. Representatives from the three universities currently operating the program lead the workshops to teach the model, offer important suggestions, and thus significantly flatten the learning curve for those trying to implement such a program. They have an incredible amount of knowledge and experience to share that will save you valuable time and other resources such as how to: (1) Recruit students from non-business majors to participate; (2) Recruit faculty representatives from across the university to help champion the program; (3) Attract and maintain sponsors; (4) Design courses appropriate for all majors; (5) Create valuable business trip experiences; (6) Collaborate with other universities operating the program; (7) Adhere to the core values of the program; and (8) Modify the model to fit your university's mission, size, and available resources. Entrepreneurship educators interested in learning more about this leading edge $21^{\text {st }}$ century entrepreneurship education model are encouraged to contact one of the authors of this paper.

\section{REFERENCES}

Begley, T. \& D. Boyd (1987). Psychological characteristics associated with performance in entrepreneurial firms and smaller businesses. Journal of Business Venturing, 2, 79-93.

Borg, J.R. \& M.O. Borg (2001). Teaching critical thinking in interdisciplinary economics. College Teaching, Winter, $49(1), 20-25$.

The Economist. (2005). Industrial metamorphosis; manufacturing employment. October.

Nunn. L.E. \& Ehlen, C.R. (2001). Developing curricula with a major emphasis in entrepreneurship -an accounting perspective. Journal of Applied Business Research, Fall, 17(4), 8p.

Emmet, R.B. (1999). The economist and the entrepreneur: Modernist impulses in risk, uncertainty, and profit. History of Political Economy, 31(1), 29-52.

Envick, B.R., T. Madison \& R. Priesmeyer (2003). An interdisciplinary approach to entrepreneurship education: The cross-course project model. Journal of Entrepreneurship Education, 6, 1-10.

Glennon, J.R. (1966). A Catalog Life of History Items. Greensboro, NC: The Richardson Foundation.

Lambing, P. \& C. Kuehl (2000). Entrepreneurship, $2^{\text {nd }}$ Ed. Prentice-Hall.

Journal of Entrepreneurship Education, Volume 9, 2006 
Osborne, S. W. (2000). From unemployed to entrepreneur: A case study in intervention. Journal of Developmental Entrepreneurship, August, 5(2).

Padmanabhan, P. \& T. Madison (2005). Global economic relations and outsourcing: The case for privately financed retraining centers. Review of Business Research, 5(3), 97-105.

Padmanabhan, P., T. Madison, \& K. Kampschroeder (2004). Outsourcing, jobs weave tangled web. San Antonio Business Journal, December.

Shane, S. \& S. Venkataramann (2000). The promise of entrepreneurship as a field of research. The Academy of Management Review, 25(1), 217-226.

Smith, B.N., J. Hornsby \& M. Kite (2000). Broadening the business curriculum via a cross-disciplinary approach. Education, 120(4), 713-722. 


\title{
MINDING OUR BUSINESS: A MODEL OF SERVICE- LEARNING IN ENTREPRENEURSHIP EDUCATION
}

\author{
Sigfredo A. Hernandez, Rider University \\ Cynthia M. Newman, Rider University
}

\begin{abstract}
Minding Our Business (MOB) is a service-learning program designed to meet community needs by advancing the personal and vocational development of urban youth through entrepreneurship education and mentoring. This paper evaluates the effectiveness of MOB as a service-learning course in terms of the short-term effect on the personal and vocational development of urban youth and mentors and the effect on mentors' learning. Key aspects of the service-learning course include a mentor training conference, the class experience and the field experience. Mentor, student and homeroom teacher surveys provide evidence of positive developmental changes occurring in MOB students. Academic records data indicate that the effect of the MOB program on students is favorable, as compared to the control group, in terms of reducing absences and tardiness to school. In addition, end-of-semester mentor surveys indicate that the experience had a positive effect on mentors' vocational and community service plans. Finally, mentor reflections in end-of-semester journal entries provide evidence of a great learning experience and of a positive impact of $M O B$ on their personal and vocational development.
\end{abstract}

\section{INTRODUCTION}

The mission of Minding Our Business (MOB), a service-learning course started in 1997 to meet community needs, is to advance the personal and vocational development of urban youth through entrepreneurship education and mentoring. Very few published accounts of service-learning efforts directed to the urban community reflect the integration of entrepreneurship education into the service-learning experience. The positioning of MOB, therefore, is quite unique among servicelearning programs.

The course's creation was supported by a competitive grant from the College of Business Administration (CBA) at a private AACSB accredited university located in the northeastern United States. Because program congruence with the mission of CBA was an important criterion in awarding the grant, the creation of the course and its learning goals were greatly influenced by the CBA's mission: to enable graduates to be socially responsible participants and to provide opportunities for experiential learning and programs to develop communication, interpersonal, 
teamwork, leadership, critical thinking and problem solving skills (XXX CBA Handbook, 2001). MOB provides CBA students with an opportunity to practice social responsibility while developing important life-work skills. Not only was fit with the CBA's mission important to securing the grant for the program's development, but also such fit is the first step toward successful institutionalization of a service-learning program (Troope \& Morton, 1996). Service-learning programs integrated into the central goals and mission of the schools and institutions in which they are based appear to have a greater chance of success (Kendall, 1990; Zlotkowski, 1998).

The purpose of this paper is to evaluate the short-term effect of MOB on the personal and vocational development of urban youth and mentors and to evaluate the effectiveness of this servicelearning course in terms of learning on the part of the CBA students (mentors). This is the first step of a larger research program to determine the short-term and long-term effects of MOB as an entrepreneurship education program for urban youth and as a service-learning course for business college students (mentors)

\section{COURSE DESCRIPTION}

MOB is an elective service-learning course for CBA sophomores, juniors and seniors. The average class enrollment of 24 students is often evenly split in terms of gender. In 2004 twenty-two mentors in this class were Caucasian, non-Hispanic, one Black (African-American) and one Guyanese. The course is taught only in the spring semester during afternoons, to coincide with the end of the school day at inner city schools. Mentors typically attend a 90 minute class one time per week and facilitate a weekly 90 minute program session with teams of middle school students (students) at an inner-city partner school.

The program works with students who are early adolescents, ages 11 to 14; typically, twothirds of these students are female. One-hundred-and-three such students participated in the 2004 spring program. Ninety-five percent of the students are African-American, three percent are Hispanic, and two percent belong to other ethnic groups. Most students are from low income families, with three-fourths of the students in the school participating in the free or reduced lunch program (D.B. Wood, personal communication, February 28, 2005).

According to the Carnegie Council on Adolescent Development (1995), early adolescents are at a critical life-stage where they begin to engage in risky behaviors but are still susceptible to positive influences by an involved adult that would enable them to grow and become contributing members of society. This is the key reason for MOB to work with early adolescents.

Young adolescents who live in poverty are more likely to lack two crucial prerequisites for their healthy growth and development: a close relationship with a dependable adult and the perception of meaningful opportunities in mainstream society (Carnegie Council on Adolescent Development 1995). Mentors, through their work in the MOB program, attempt to meet these two key prerequisites to student growth.

Journal of Entrepreneurship Education, Volume 9, 2006 
A weekend-long training conference at the start of the semester and in-class learning activities help mentors prepare for their role as mentors/facilitators. Also, they learn basic entrepreneurship concepts and how to facilitate the 12 week entrepreneurship curriculum at the partner school.

Since reflection is an essential element of service-learning (e.g. Jacoby, 1996; Mintz \& Hesser, 1996; Godfrey, 2000; Howard, 2001), this activity plays a very important role in this service-learning course. The role of reflection in the pedagogy of MOB is best expressed by Jacoby (1996, p. 6): “As a form of experiential education, service-learning is based on the pedagogical principle that learning and development do not necessarily occur as a result of experience itself but as a result of a reflective component designed to foster learning and development." Hence, reflection on the part of MOB mentors occurs in both the classroom and field experiences.

MOB learning goals for mentors are presented in Table 1. Two of the goals are affectivemoral and refer to the practice of social responsibility and the respect that all mentors should develop for others. Three of the goals relate to the development of team, mentoring and communication skills. The remaining five goals are cognitive. These learning goals were designed with the intent of requiring mentors to de-emphasize memorization in favor of deep learning. Each of these five goals is followed by the highest thinking level required (in caps) based on Bloom's taxonomy of learning objectives (Bloom, 1956). Four of the five goals refer to the learning expected from helping inner city students to run a business. The remaining goal "practicing guidelines for the creation of an effective team" is important because the mentors are facilitating team businesses in the field and are themselves part of learning teams in the classroom.

\section{Mentor Training Conference}

Because mentors need to be prepared for mentoring and facilitating student teams at the partner middle school during the first week of February, they undergo intensive training during the last weekend of January. The mentors receive twenty-hours of training at the weekend conference for the purpose of: learning their role as mentors-facilitators, becoming familiar with the MOB curriculum, and getting to know their co-mentors.

The six person training team for the mentors typically includes a professional trainer, university staff members, MOB alumni mentors, and the instructor. The members of the team with more training experience take on a lead role during the weekend conference.

The key objective of the training is for mentors to learn their roles as mentors-facilitators. As facilitators they are expected to provide inner-city students opportunities for meaningful participation. These students then become the key actors in the learning process. They, and not the mentors, are the ones making the key business decisions: selecting a business, naming it, and deciding how to market and run it. The mentors are the guides on the side. Through these 
opportunities for meaningful participation students can further their development, which is what mentors do: help further the development, typically, of younger others (Daloz, 1999).

\section{Table 1: Minding Our Business Learning Goals}

Each learning objective is followed by the highest thinking level it requires or whether it refers

to affective/moral or skill development.

Develop a strong sense of social responsibility for the youth of the partner middle-school.

AFFECTIVE/MORAL

Understand the basic principles associated with the operation of an effective team.

COMPREHENSION

Become a more effective team player. SKILL DEVELOPMENT

Develop mentoring and team facilitation skills. SKILL DEVELOPMENT

Improve leadership and communication skills. SKILL DEVELOPMENT

Develop sensitivity and respect for social class, ethnic and racial diversity.

AFFECTIVE/MORAL

Understand some of the main issues and concerns of pre-adolescent development.

COMPREHENSION

Apply the basic concepts of entrepreneurship to a student run business. APPLICATION

Facilitate the process of starting and running a business. APPLICATION

Set up a projected income statement for a small business. APPLICATION

The groups' structure at the training conference switches back and forth from one large group containing all the mentors to two groups of about 15 members each. Contained within these two group structures are the mentor teams, trainers, and conference guests. Each mentor team is composed of three mentors who are expected to facilitate a team of students at the partner school through the process of starting and running a business. Mentors are required to sit together in their co-mentor teams and to perform team building activities together. By the end of the training mentor teams begin to develop cohesiveness.

In the large group structure trainers review important program information, facilitate team building activities for the co-mentor teams, and encourage reflection and discussion about the 
learning experience, in general, and about mentors' roles as facilitators, in particular. While in the two-group structure, two or three trainers who are attached to each group model team facilitation of the MOB program sessions to the mentors. The use of two to three trainers per group as cofacilitators is desirable since this situation is similar to what the mentors will experience in the field where three mentors are assigned as facilitators to each student team. Trainers encourage mentors at the conference to think about ways of effectively facilitating program sessions.

Facilitation is structured by the Learning Cycle 5-step model developed by the Princeton Center for Leadership Training (1997). Trainers model the learning cycle in their facilitation: 1.making a bridge between the last activity and this one, 2. introducing the theme, 3. giving directions, 4. participating in the activity, and 5. reflecting on the activity. Mentors are instructed in the learning cycle and particularly reminded of the importance of the last step: reflecting. They are told that most of the learning in a particular team activity occurs not during the performance of the activity but after, in the reflection that should follow (Jacoby, 1996). Therefore, facilitators are expected to encourage reflection with their student groups and are trained to do so.

On the last day of training the large group takes on the form of a fish-bowl structure where two co-mentor teams role play or simulate the facilitation of a program session and other mentors play student roles during the simulations. The remaining mentors and the trainers (outside the fishbowl) help provide feedback to the role play facilitators.

Guests to the training conference often include the liaison/coordinator of MOB at the partner school and a few students from the previous year's MOB program. The liaison person is very helpful in answering questions about the host school. MOB student alumni often participate throughout the training with the current mentors. In addition, they help these mentors become more comfortable and familiar with the types of students that they will be working with at the partner school.

\section{Class Experience}

Since the course creation in 1997, a cooperative learning pedagogy has been used in the classroom in a manner consistent with the team mentor concept applied in the field. In 1999 the instructor adopted the Instructional Activity Sequence (IAS) developed by Michaelsen (1994) for classroom use. In this model of cooperative learning, college students, not the instructor, cover the material outside class. Mentors are tested on key concepts when they come to class. IAS increases students' preparedness for applying the concepts that they have studied individually (Michaelsen \& Black, 1994). IAS appears to improve mentor preparation to apply key mentoring, entrepreneurship and team concepts at the mentoring sessions and/or in class.

Co-mentor teams of three mentors are formed by the instructor on the first day of class, prior to the training conference. College students are more likely to have a positive team learning experience in classes where groups are formed by the instructor (Fiechtner \& Davis, 1985; Michaelsen, 1994). The teams are permanent in class and in the field for the duration of the course 
because permanent groups offer the best opportunities for group cohesiveness to develop (Fiechtner $\&$ Davis, 1985). Based on data gathered from each mentor prior to the first day of class, these teams also tend to be heterogeneous in terms of gender, their potential for academic achievement (GPA as a proxy) and their prior experience in working with preadolescents. The selection of heterogeneous groups is preferable given the advantages of spreading member assets/liabilities equitably among groups (Michaelsen, 1994; Bacon, Stewart, \& Stewart-Belle, 1998).

Team activities are designed in order to stimulate reflection and application of key concepts in three main areas of knowledge: mentoring, teams and entrepreneurship. These activities also tend to promote cohesiveness among co-mentor teams. The knowledge tested and applied in class often corresponds to the knowledge that mentors need to apply in the field when they visit the partner school later in the same week. The class schedule is then designed to support the program sessions in the field. For instance, the first two program sessions in the field are on team building and in the two corresponding class sessions mentors are tested and/or asked to apply knowledge learned from their individual study of material that is relevant to these two sessions: mentoring, the learning cycle, active listening, the art of group facilitation, how to create an effective group and encouraging participation.

In accordance with the course pedagogical philosophy that reflection is where learning takes place, mentors are required to submit weekly journal writings. Written reflection is widely viewed by students in service-learning courses as the most important technique for learning (Eyler, Giles, $\&$ Schmiede, 1996). Mentors submit weekly unstructured journal writings for the purpose of reflecting about their mentoring experience in each program session. In addition, mentors are often required to submit structured writings where they receive questions to guide their reflection on a particular experience or reading. For instance, they are asked to reflect about what facilitation skills and traps were experienced during the second week's session using the reading "The Art of Group Facilitation" as a reference. Several studies have found that the amount of structured reflection incorporated into service-learning courses is related to student learning (Eyler \& Giles, 1999; Mabry, 1998). Many of the in-class team learning activities also require mentors to share their reflections with their co-mentors.

\section{Field Experience}

The team learning model used in the field portion of the course was originally adopted from the Princeton Center for Leadership Training in 1997, a non-profit organization specializing in the creation and operation of youth development programs. The mentoring experience is structured in the field through a 12 week activity-based entrepreneurship curriculum involving 13 program sessions. The sessions are: 1. Building a Team I, 2. Building a Team II, 3. Introduction to Entrepreneurship, 4. Selecting and Naming Your Business, 5. Pricing and Promoting Your Business, 6. Advertising that Works, 7. Your Business Plan, 8. Business Plan Presentations, 9. Getting Ready

Journal of Entrepreneurship Education, Volume 9, 2006 
for Market Fair, 10. Market Fair, 11. Sharing Successes and Challenges, 12. Visit to Trenton Area Businesses, and 13. Reflections and Next Steps. The curriculum was developed in collaboration with the Princeton Center for Leadership Training (1997). Each mentoring team facilitates a team of ten to fifteen middle school students through the process of starting and running a business. In 2004 a total of 103 students and 24 mentors participated in the program and were organized into eight teams.

The first two sessions are designated for team building since at this point in the program the mentors and students are in the forming stage of group development (Tuckman and Jensen, 1977) and need to get to know each other and develop group ground rules before making any important business decisions. Various icebreaker activities are used during these two sessions in order to advance the process of coming together as a team. The first session, in particular, is about getting to know each other and about discussing program objectives and student expectations. Many mentors express a sense of relief after the first session as some of their worst fears and expectations are disconfirmed.

In the next six sessions students learn entrepreneurship and make important business decisions including the selection of a business, the choice of a business name, the decision of how to market the business, and the development of a business plan.

In the eighth session students and mentors face their first major business/team challenge. MOB teams, with students taking the lead role, present their business plans to a panel of business community leaders and CBA faculty in order to obtain loans for implementing their business plans. Mentors often express pride in their journals about their students' performance at the business plan presentations. The average loan granted is about $\$ 150$ and is based on the merits of the business idea and the quality of the plan. The loans are zero interest seed money payable after students run their businesses at the school market fair. The loan default rate is very low. Only an average of four percent of all loan money during the 1997 to 2004 period was not paid back by the student businesses.

After obtaining their loans, MOB teams prepare to run their businesses at the school market fair on the first Saturday of April. Table 2 lists the 8 teams, their business names, and the products sold at the 2004 market fair. This is the big day that MOB students and mentors have anxiously waited for: to succeed in running their businesses.

The market fair is also a fun event for the MOB teams and the school community. Teachers and students at the partner school organize a teen talent show to take place at the fair. Drill teams, a DJ and a music band also contribute to make it an entertaining event. The entertainment helps attract people from the local community and improves the odds of success for the student-run businesses. Most student-run businesses in the eight year history of the program have been profitable. In 2004 approximately 400 people attended the event and six out of eight team businesses were profitable; the other two were very close to breaking even. 


\begin{tabular}{|c|l|l|}
\hline \multicolumn{3}{|c|}{ Table 2: 2004 Minding Our Business Student Run Businesses } \\
\hline Team \# & \multicolumn{1}{|c|}{ Business Name } & \multicolumn{1}{c|}{ Products/Services Sold } \\
\hline 1 & Hoops N Prizes & Hoops game, candy, popsicles \& T-shirts \\
\hline 2 & The Hip Hop Accessory Shop & Head bands, cell phone cases \\
\hline 3 & Food Paradise & Pizza, hot wings, soft-drinks \\
\hline 4 & The Hip Hop Food Shop & Fried chicken, mac \&cheese, soda, desserts \\
\hline 5 & Wild Wings Snack Shack & Hotdogs, chicken wings, drinks, snacks \\
\hline 6 & It's Really Hot & T-shirts, pictures, hotdogs, drinks, candy \\
\hline 7 & Hot Stuff and Refreshing Things & Beverages and food \\
\hline 8 & Create T's and More & T-shirts, bands, socks, tank tups \\
\hline
\end{tabular}

The mentors face one of the greatest facilitation challenges in session eleven, after the market fair. They have to convince students that the program is not over and that the most significant program learning does not take place in the market fair, but in the reflection that follows. This is the theme of the session titled "Sharing Successes and Challenges". Mentors facilitate the reflection on how the students performed as a team and as a business at the market fair and how performance could be improved if they were going to do it all over again. Profitable teams decide what to do with their profits - they often spend the money on a food party to take place at the school cafeteria on the last session of the program. Mentors of teams that lost money have a more difficult challenge in convincing students that the greater success is in the learning experience and that many entrepreneurs become successful by learning from past failures. Mentors of non-profitable teams often pay from their own pockets for the team's food party at the end of the program.

In session twelve MOB teams visit successful businesses in the local community. Mentors ensure that students prepare questions in advance for the host entrepreneur. After eating the snacks provided by the host business, the students receive a guided tour of the facilities and the opportunity to ask their questions to the owner or manager.

In the last program session students reflect about their learning experience and share plans for the future. The session starts with students completing their program evaluation forms, which sets the stage for the reflection that follows. The session concludes with "The Web", an activity designed for students and mentors to express appreciation for the team experience and for each other. The session is immediately followed in the school cafeteria by the team's food party. This is the adjourning stage of the team development process (Tuckman and Jensen 1977) and is a time of mourning and celebration. 


\section{MEASURES}

Surveys are conducted at the conclusion of the program among mentors, students, and their homeroom teachers. These three surveys represent three different perspectives on how well the program is working (measure triangulation) with students. This adds face validity to the assessment of student impact.

\section{MOB Effect on Students}

Mentors evaluate the students that regularly attend the program sessions and are members of their MOB teams, after completing the program. Student changes are evaluated on seven dimensions: getting along with others, ability to communicate, confidence, participation, leadership, motivation to learn, and knowledge of entrepreneurship. The mentors are asked to evaluate changes observed in the students through MOB as positive, negative or as no change.

Students, on the last day of the program, complete a program evaluation survey in which they evaluate changes in themselves as a result of their participation in MOB, answer questions about their plans for the future, and indicate how much they liked/disliked the program. The questions addressing changes in students as a result of their participation in MOB include getting along with others, ability to communicate, feeling about self, leadership skills, skills as an entrepreneur, liking for school, ability as a team member, and ability as a student.

Homeroom teachers are asked to evaluate their MOB students at the conclusion of the program in terms of the changes observed in them from the start date of the program to the end date. The teachers evaluate the MOB students' changes (positive, negative or no change) on five areas: attendance, grades, confidence, ability to communicate, and attitude toward learning.

At the end of the 2003-2004 academic year data were collected from students' academic records at the partner school. Data on grades, absences and tardiness were gathered for MOB students and students in a control group. The information from the student academic records was recorded for the end of the second marking period, which almost coincides with the start of the program, for the third marking period, and for the fourth marking period, after the end of the program. The control group was selected at random from a list of all partner school students organized in alphabetical order. The control group was matched to the MOB student group by

gender with two-thirds of the students being female. Both samples contained 103 students for a total of 206 students

\section{MOB Effect on Mentors}

The effect of MOB on mentors is measured by mentors' evaluations of the learning experience in class and in the field. Mentors' evaluations of their learning experience are obtained 
from end-of-semester course evaluations, surveys and journals. Questions in the course evaluation survey are organized under the following themes: meeting learning objectives, course effect on learning, team learning, quizzes, the instructor, the speaker mentors, and overall evaluation. The most relevant questions to assess MOB course effect on the personal and vocational development of the mentors are those pertaining to meeting learning objectives and course effect on learning.

Mentors are asked to indicate how well the course learning objectives were met. For each learning objective mentors are asked to report if the objective was met very well, well, not that well, or not well at all. The course effect on learning portion of the survey contains a truncated Likert scale (strongly agree, agree, disagree, or strongly disagree) for six items including effect on student interests, betterment as a mentor, and quality of the learning experience.

In an end of semester survey, mentors are asked to indicate, using a Likert scale, their level of agreement/disagreement with five statements concerning the effect of MOB on their plans for the future. This short survey includes questions on mentors' plans to do more community service, desire to start their own businesses, perceived edge in the job market because of MOB experience, interest in working with kids, and MOB effect on career plans.

In end-of-semester mentor journals, mentors are asked to reflect about their MOB learning experience and to share their most memorable MOB experience. Multiple reflection triggers in the form of questions are provided to guide mentors' reflections about the quality of the learning experience and the effect of MOB on their personal and vocational development. Hamner (2002) suggests multiple reflection triggers to facilitate reflection by the service-learner. The mentors are told that they are not expected to address all the reflection triggers (questions) but to answer as many as they can.

\section{EFFECTIVENESS AS A SERVICE-LEARNING COURSE}

\section{Effect on Middle-School Students}

Table 3 indicates that the majority of the students at the partner school completing the 2004 Student Survey perceived positive changes in self as a result of their participation in the program. Students perceived that they had better entrepreneurship skills (72\%), leadership skills (71\%), feelings about self $(69 \%)$, team skills (59\%), and ability to communicate (53\%). They also thought

of themselves as better students (51\%) and thought they were able to get along better with family $(50 \%)$ as a result of their participation in MOB. In addition, 47 percent of the students perceived getting along better with teachers and 46 percent indicated getting along better with other students as result of MOB.

As reported in Table 4, students also commented on the effect of MOB on their future plans. Sixty-five percent of all students reported being more interested in a career in entrepreneurship and fifty-one percent reported being more interested in going to college because of MOB. Fifty-six 
percent of all students expressed interest in participating in the MOB Summer Program. In addition, seventy-four percent of all students indicated having a little more (37\%) or greater (37\%) desire than they had before MOB to start their own businesses.

\begin{tabular}{|l|c|c|c|}
\hline \multicolumn{1}{|c|}{ Table 3: 2004 Student Survey - Perceived Changes in Self as a Result of Participation in MOB (n=80) } \\
\hline \multicolumn{1}{|c|}{ Item } & \multicolumn{2}{c|}{ Changes in Self (percentages) } \\
\hline Entrepreneurship skills & 72 & 25 & Worse \\
\hline Leadership skills & 71 & 25 & 4 \\
\hline Feelings about self & 69 & 30 & 1 \\
\hline Team skills & 59 & 39 & 2 \\
\hline Ability to communicate & 53 & 46 & 1 \\
\hline As a student & 51 & 45 & 4 \\
\hline Getting along with family & 50 & 49 & 1 \\
\hline Getting along with teachers & 47 & 47 & 5 \\
\hline Getting along with other students & 46 & 50 & 4 \\
\hline
\end{tabular}

\begin{tabular}{|l|c|c|c|}
\hline \multicolumn{2}{|c|}{ Table 4: 2004 Student Survey - Effect of MOB on Future Plans (n=80) } \\
\hline Item & \multicolumn{2}{|c|}{ MOB Effected Future Plans (in percentages) } \\
\hline & Yes & I Don't Know & No \\
\hline More interested in a career in entrepreneurship & 65 & 18 & 17 \\
\hline More interested in going to college & 51 & 20 & 28 \\
\hline More interested in MOB Summer Program & 56 & 26 & 18 \\
\hline
\end{tabular}

Table 5 shows that mentors completing the 2004 Mentor Survey observed positive changes in a large majority of students as a result of MOB: in their greater knowledge of entrepreneurship (70\%), increased ability to communicate $(69 \%)$, gained confidence $(67 \%)$, increased participation (64\%), more motivated to learn (59\%), getting along with others (55\%), and improved leadership skills $(45 \%)$.

Table 6 presents homeroom teachers' perceptions of MOB student changes taking place during the program. Positive changes were observed in MOB students, particularly in their selfconfidence $(58 \%)$, their ability to communicate $(48 \%)$, and their attitude toward learning (38\%). Positive changes were observed in student attendance (30\%) and school grades (28\%) but they were not as significant as the other changes. 


\begin{tabular}{|l|c|c|c|}
\hline \multicolumn{1}{|c|}{$\begin{array}{c}\text { Table 5: Mentor Survey - Changes Observed in MOB Students } \\
\text { Based on 293 student evaluations conducted by 24 mentors }\end{array}$} \\
\hline \multicolumn{1}{|c|}{ Item } & \multicolumn{2}{c|}{ Changes (in percentages) } \\
\hline Knowledge of entrepreneurship & 70 & 21 & Worse \\
\hline Ability to communicate & 69 & 21 & 11 \\
\hline Confidence & 67 & 26 & 8 \\
\hline Participation & 64 & 24 & 12 \\
\hline Motivation to learn & 59 & 29 & 12 \\
\hline Getting along with others & 55 & 37 & 8 \\
\hline Leadership skills & 45 & 40 & 15 \\
\hline
\end{tabular}

\begin{tabular}{|l|c|c|c|}
\hline \multicolumn{2}{|c|}{$\begin{array}{c}\text { Table 6: Home-Room Teacher Survey - Changes Observed in MOB Students } \\
\text { Based on home-room teacher evaluations of 80 MOB students }\end{array}$} \\
\hline \multicolumn{2}{|c|}{ Item } & \multicolumn{3}{c|}{ Changes (in percentages) } \\
\hline & Better & Same & 11 \\
\hline Self-confidence & 58 & 31 & 15 \\
\hline Ability to communicate & 48 & 38 & 27 \\
\hline Attitude toward learning & 38 & 35 & 13 \\
\hline School attendance & 30 & 58 & 27 \\
\hline School grades & 28 & 46 & \\
\hline
\end{tabular}

Academic record data allows the evaluation of MOB effect on students' performance in two general areas: interest in school as demonstrated by their attendance/punctuality patterns and academic achievement as represented by their GPA. Marking periods of interest were period 2 (at the start of the program), period 3 (during and after the program), and period 4 (after the program).

The rate of absenteeism for MOB students during all marking periods of interest were lower than for students in the control group $(\mathrm{p}<.05)$. Except for marking period 2, where tardiness rates were equal between both groups, tardiness rates $(p<.05)$ were lower for MOB students than for students in the control group. Student academic achievement, as measured by GPA, was higher for MOB students $(p<.05)$ than for students in the control group for all marking periods. These results are presented in Table 7. Although, the program has an open enrollment policy the finding suggests that MOB may be serving a higher achieving sample of students in terms of grades and attendance/punctuality. These students may very well be more motivated to achieve which drives their desire to participate in the program. 
Table 7: Independent Sample Tests - GPA, Absences and Tardiness for MOB Students and Control Group: Marking Periods 2, 3 \& 4

\begin{tabular}{|l|c|c|c|c|}
\hline \multirow{2}{*}{ Variable } & \multicolumn{4}{|c|}{ T-Test for Equality of Means } \\
\cline { 2 - 5 } & Mean Difference & $\mathrm{t}$ & $\mathrm{df}$ & Sig. \\
\hline Absences2 & .06 & 1.79 & 196 & .04 \\
\hline Absences3 & 1.74 & 2.96 & 197 & .00 \\
\hline Absences 4 & 2.22 & 2.82 & 196 & .00 \\
\hline Tardiness2 & .00 & 0.00 & 196 & 1.00 \\
\hline Tardiness3 & 2.62 & 3.14 & 197 & .00 \\
\hline Tardiness4 & 1.89 & 3.94 & 197 & .00 \\
\hline GPA2 & -1.33 & -3.43 & 198 & .00 \\
\hline GPA3 & -1.00 & -2.69 & 196 & .00 \\
\hline GPA4 & -.83 & -2.20 & 194 & .01 \\
\hline
\end{tabular}

Academic record data were used in the conduct of paired t-tests to compare attendance, tardiness, and GPA measures at the start of the program to these measures after the program ended. The purpose of these analyses (Table 8) is to determine if there were significant changes in absenteeism, tardiness, and GPA within the two groups of students from the start of the program to after. Both groups of students have higher rates of absenteeism and tardiness in marking periods 3 and 4 than in marking period 2, prior to the program's start. GPA only increased between the second and third marking period for students in the control group $(\mathrm{p}<.05)$, while there were no significant changes in MOB student GPA.

\begin{tabular}{|c|c|c|c|c|c|c|c|c|}
\hline \multicolumn{9}{|c|}{$\begin{array}{l}\text { Table 8: Paired Sample Tests - GPA, Absences and Tardiness for MOB Students and Control Group: } \\
\text { Marking Periods } 2,3 \& 4\end{array}$} \\
\hline \multirow[t]{2}{*}{ Pair } & \multicolumn{4}{|c|}{ MOB Students } & \multicolumn{4}{|c|}{ Control Group } \\
\hline & Mean & $\mathrm{t}$ & $\mathrm{df}$ & Sig & Mean & $\mathrm{t}$ & $\mathrm{df}$ & Sig \\
\hline Absences2-Absences3 & -2.8 & -9.5 & 97 & .00 & -4.4 & -8.8 & 99 & .00 \\
\hline Absences2-Absences4 & -3.6 & -9.0 & 93 & .00 & -5.7 & -8.6 & 99 & .00 \\
\hline Tardiness2-Tardyness3 & -4.1 & -7.4 & 97 & .00 & -6.7 & -10.7 & 99 & .00 \\
\hline Tardiness2-Tardyness4 & -1.8 & -6.2 & 94 & .00 & -3.7 & -9.5 & 99 & .00 \\
\hline GPA2-GPA3 & -.0 & -.2 & 97 & .84 & -.5 & -2.1 & 97 & .02 \\
\hline GPA2-GPA4 & .3 & 1.3 & 94 & .10 & -.3 & -1.2 & 96 & .13 \\
\hline
\end{tabular}


Table 9 shows that MOB students, when compared to students in the control group, experience lesser increases in absenteeism and tardiness from marking period 2 to marking periods 3 or $4(\mathrm{p}<.05)$. However, the change in GPA from marking period 2 and 3 was not significantly different between groups. The increase in GPA for the control group from marking period 2 to the last marking period was larger than for the MOB group but only marginally significant $(\mathrm{p}=.05)$. This particular finding could be explained by the fact that students in the control group can be characterized as lower academic achievers (lower GPA) than the students in the MOB group. Because of this, students in the control group are more likely to make an extra effort, as compared to MOB students, to improve grades in the last marking period in order to avoid academic failure or having to attend summer school to retake failed courses.

\begin{tabular}{|l|c|c|c|c|c|c|}
\hline \multicolumn{2}{|c|}{ Table 9: Independent Sample Tests - Changes in GPA, Absences and Tardiness for MOB Students and } \\
Control Group for Marking Periods 2, to Marking Periods 3 \& 4
\end{tabular}

In summary, although MOB may be serving a higher achieving sample of students, the comparative and within group analyzes of academic record data indicate that participation in the MOB program does not appear to effect student GPA. However, program participation does appear to have a mitigating effect on attendance and punctuality as evidenced by the smaller increases in absenteeism and tardiness for MOB students than for students in the control group

\section{Effect on Mentors}

End-of-semester mentors' course evaluations provide self-report evidence of course objectives being met well or very well for most mentors (see Table 10). Some of these objectives refer to the development of important life-work skills, social responsibility, and greater sensitivity and respect for diversity. 


\begin{tabular}{|l|c|c|c|c|}
\hline \multicolumn{2}{|c|}{ Table 10: Meeting Learning Objectives -- 2004 Course Evaluations (percent responses), $\mathbf{n = 2 1}$} \\
\hline & $\begin{array}{c}\text { Very } \\
\text { Well }\end{array}$ & Well & $\begin{array}{c}\text { Not } \\
\text { That } \\
\text { Well }\end{array}$ & $\begin{array}{c}\text { Not Well } \\
\text { at All }\end{array}$ \\
\hline Objectives & & & & \\
\hline $\begin{array}{l}\text { 1. Develop a strong sense of social responsibility for the youth } \\
\text { of the school being served. }\end{array}$ & 71 & 29 & 0 & 0 \\
\hline $\begin{array}{l}\text { 2. Understand and practice guidelines for creating an effective } \\
\text { team. }\end{array}$ & 76 & 24 & 0 & 0 \\
\hline 3. Become a more effective team player. & 62 & 38 & 0 & 0 \\
\hline 4. Develop mentoring and team facilitation skills. & 86 & 14 & 0 & 0 \\
\hline 5. Improve leadership and communication skills. & 71 & 29 & 0 & 0 \\
\hline $\begin{array}{l}\text { 6. Develop sensitivity and respect for social class, ethnic and } \\
\text { racial diversity. }\end{array}$ & 71 & 29 & 0 & 0 \\
\hline $\begin{array}{l}\text { 7. Understand some of the main issues and concerns of pre- } \\
\text { adolescent development. }\end{array}$ & 57 & 38 & 5 & 0 \\
\hline $\begin{array}{l}\text { 8. Apply the basic concepts of entrepreneurship to a student run } \\
\text { business. }\end{array}$ & 67 & 33 & 0 & 0 \\
\hline 9. Facilitate the process of starting and running a business. & 57 & 43 & 0 & 0 \\
\hline 10. Set-up a projected income statement for a small business. & 60 & 35 & 5 & 0 \\
\hline
\end{tabular}

As can be seen in Table 11 the course appears to have a favorable effect on the mentors' learning and to favorably influence mentors' vocational interests. Eighty-five percent of all mentors disagreed or strongly disagreed with the statement, "This course diminished my interest in entrepreneurship." Ninety-five percent of all mentors agreed or strongly agreed with "This course increased my interest with teams and team management." Eighty-six percent disagreed or strongly disagreed with the statement "This course diminished my interest in mentoring". All mentors agreed or strongly agreed with the statement "This course helped me become a better mentor by providing me with opportunities to reflect about my own mentoring." Finally, all mentors agreed or strongly agreed that this course was a great learning experience.

According to results of end-of-semester mentor surveys, the course appears to have a significant influence on mentors' community service and career plans as indicated in Table 12. Sixty-seven percent strongly agreed or agreed with the assertion that they plan to do more community service in the future. Sixty-six percent strongly agreed or agreed that they are more interested in working with kids in the future as a result of their experience in MOB. Forty-three percent strongly agreed or agreed with a greater desire to start their own businesses and with the statement that MOB gave them an edge in the job market. Thirty-four percent strongly agreed or agreed that MOB had a significant effect on their career plans. 


\begin{tabular}{|c|c|c|c|c|}
\hline \multicolumn{5}{|c|}{ Table 11: Course Effect on Learning - 2004 Course Evaluations (percent responses), $\mathbf{n = 2 1}$} \\
\hline Effect of Learning & $\begin{array}{l}\text { Strongly } \\
\text { Disagree }\end{array}$ & Disagree & Agree & $\begin{array}{l}\text { Strongly } \\
\text { Agree }\end{array}$ \\
\hline This course diminished my interest in entrepreneurship. & 33 & 52 & 14 & 0 \\
\hline $\begin{array}{l}\text { This course increased my interest in teams and team } \\
\text { management. }\end{array}$ & 0 & 5 & 62 & 33 \\
\hline This course diminished my interest in mentoring. & 38 & 48 & 14 & 0 \\
\hline $\begin{array}{l}\text { This course help me become a better mentor by providing } \\
\text { me with opportunities to reflect about my own mentoring. }\end{array}$ & 0 & 0 & 52 & 48 \\
\hline This course was a great learning experience. & 0 & 0 & 24 & 76 \\
\hline
\end{tabular}

\begin{tabular}{|c|c|c|c|c|c|}
\hline \multicolumn{6}{|c|}{$\begin{array}{l}\text { Table 12: Career Plans Influenced by MOB -- } 2004 \text { End-of-Semester Mentor Surveys } \\
\text { (percent responses), } \mathbf{n = 2 1}\end{array}$} \\
\hline Plans & $\begin{array}{l}\text { Strongly } \\
\text { Disagree }\end{array}$ & Disagree & Neither & Agree & $\begin{array}{l}\text { Strongly } \\
\text { Agree }\end{array}$ \\
\hline Plan to do more community service in the future & 5 & 5 & 24 & 62 & 5 \\
\hline Greater desire to start own business & 5 & 10 & 43 & 33 & 10 \\
\hline MOB is giving me an edge in the job market & 10 & 0 & 48 & 33 & 10 \\
\hline I am more interested in working with kids & 5 & 5 & 24 & 52 & 14 \\
\hline $\begin{array}{l}\text { MOB had a significant impact on my career } \\
\text { plans }\end{array}$ & 10 & 5 & 52 & 24 & 10 \\
\hline
\end{tabular}

A content analysis of twenty-four mentor journals at the end of the semester indicates that the field experience is the most significant part of the learning experience. The field experience is the repeated subject of reflection, while the class experience is hardly ever mentioned in the journals. Mentors were asked about their most memorable experience in MOB. Twelve mentors (half) identified the Market Fair as their most memorable experience. Five mentors recognized the first MOB session as the most remembered, while two mentors credited the training conference and two others the business plan presentation as most memorable.

In addition, mentors' end-of-semester reflections provide evidence of the quality of the learning experience and the effect of MOB on their personal and vocational development. Sample student reflections are displayed in Tables 13 and 14. Their reflections were coded as responses to the reflection questions provided. Not all mentors responded to all the reflection triggers supplied since they were not required to do so. The number of student reflections per response category appears on the second column of the tables. The total number of coded reflections exceeds the number of mentors submitting their end of semester journals, twenty four mentors, because mentors reflected on multiple questions. 


\begin{tabular}{|c|c|c|}
\hline \multicolumn{3}{|c|}{ Table 13: End-of Semester Mentor Journals - Quality of the Learning Experience, $\mathbf{n}=\mathbf{2 4}$} \\
\hline $\begin{array}{l}\text { Quality of the } \\
\text { Learning }\end{array}$ & \# & Reflections \\
\hline \multirow{4}{*}{$\begin{array}{l}\text { No other courses } \\
\text { compare to MOB }\end{array}$} & \multirow[t]{4}{*}{19} & I have never learned so much as I did in my MOB class. \\
\hline & & $\begin{array}{l}\text { The courses that I am taking now do not compare to MOB, because MOB is } \\
\text { hands on, and you are actually making a } \\
\text { difference in the community... }\end{array}$ \\
\hline & & It is not like any other class offered, so what do you have a comparison on? \\
\hline & & This class is based around a life changing program. \\
\hline \multirow[t]{3}{*}{ I learned about myself } & \multirow[t]{3}{*}{$12^{1}$} & $\begin{array}{l}\text { What I learned from myself is that I was quick to judge and easily frustration } \\
\text { in the beginning, and now I see myself being more open minded, and I have } \\
\text { learned patience is more needed for me than for the kids. }\end{array}$ \\
\hline & & $\begin{array}{l}\text { I learned that I'm capable of helping others... that I have some things in } \\
\text { common with all the children ... I am definitely not the same person that I } \\
\text { was at the beginning. }\end{array}$ \\
\hline & & The most important thing that I learned is that everyone is not as lucky as me \\
\hline \multirow[t]{3}{*}{$\begin{array}{l}\text { I learned about the } \\
\text { kids }\end{array}$} & \multirow[t]{3}{*}{17} & $\begin{array}{l}\text { I also learned that no matter what I read or hear I know a different side of } \\
\text { these kids now. }\end{array}$ \\
\hline & & $\begin{array}{l}\text { I came to understand their behavior more and more. ... that these students had } \\
\text { great potential. }\end{array}$ \\
\hline & & Kids need attention, love, and a nurturing environment to grow. \\
\hline \multirow{3}{*}{$\begin{array}{l}\text { I learned team and } \\
\text { mentoring skills }\end{array}$} & \multirow[t]{3}{*}{17} & I feel that I have learned great mentoring skills in the program... \\
\hline & & $\begin{array}{l}\text { I learned many team skills in working with co-mentors, and mentoring skills } \\
\text { in leading students. I learned that you have to lead by example... }\end{array}$ \\
\hline & & $\begin{array}{l}\text { The skills that I learned at MOB I will carry with me to other aspects of my } \\
\text { life. ... I learned team work and the actual meaning of mentoring. }\end{array}$ \\
\hline \multirow[t]{3}{*}{$\begin{array}{l}\text { I learned about } \\
\text { entrepreneurship }\end{array}$} & \multirow[t]{3}{*}{11} & $\begin{array}{l}\text { This program allowed me to really use the knowledge that I have about } \\
\text { entrepreneurship. }\end{array}$ \\
\hline & & $\begin{array}{l}\text { I learned that in entrepreneurship everything does not always work out as } \\
\text { planned... }\end{array}$ \\
\hline & & $\begin{array}{l}\text { As a matter of fact I don't even think I really knew what an entrepreneur was } \\
\text { exactly until this class started and we became entrepreneurs ourselves. }\end{array}$ \\
\hline \multirow[t]{3}{*}{$\begin{array}{l}\text { MOB prepared me for } \\
\text { the world of work }\end{array}$} & \multirow[t]{3}{*}{$14^{2}$} & $\begin{array}{l}\text { The MOB program definitely prepared me for the work world because it gave } \\
\text { me confidence in myself, a confidence that I haven't had for the past two } \\
\text { years. }\end{array}$ \\
\hline & & $\begin{array}{l}\text { The diversity that is apparent in this program is perhaps the best thing gained } \\
\text { toprepare someone for work. }\end{array}$ \\
\hline & & $\begin{array}{l}\text { MOB definitely helped me develop some new skills that will help me in the } \\
\text { world of work such as patience an understanding of how other people think. }\end{array}$ \\
\hline
\end{tabular}




\begin{tabular}{|c|c|c|}
\hline \multicolumn{3}{|c|}{ Table 13: End-of Semester Mentor Journals - Quality of the Learning Experience, n=24 } \\
\hline $\begin{array}{l}\text { Quality of the } \\
\text { Learning }\end{array}$ & \# & Reflections \\
\hline \multirow{3}{*}{$\begin{array}{l}\text { I would recommend } \\
\text { MOB to my } \\
\text { best friend }\end{array}$} & \multirow[t]{3}{*}{$20^{3}$} & I wish every college student were able to get involved with this program. \\
\hline & & $\begin{array}{l}\text { MOB has been my favorite class I have taken so far at xxx and have already } \\
\text { suggested it to many of my friends on campus. }\end{array}$ \\
\hline & & $\begin{array}{l}\text { I will definitely recommend this program to my friends because I think that } \\
\text { every college student should have an experience like this because is so } \\
\text { beneficial both ways. }\end{array}$ \\
\hline Total Reflections & 109 & \\
\hline \multicolumn{3}{|c|}{$\begin{array}{l}{ }^{1} \text { One other mentor said: "To be honest I did not learn too much about myself in this program." } \\
{ }^{2} \text { One other mentor disagree: "MOB did not really prepare me for the work world because I am not aiming at } \\
\text { being an entrepreneur". }\end{array}$} \\
\hline \multicolumn{3}{|c|}{${ }^{3}$ One other mentor would not recommend MOB to his best friend because: "He just doesn't have the patience." } \\
\hline
\end{tabular}

The following reflections from mentors in Table 13 provide evidence of the quality of the learning experience (number of reflections in parenthesis): no other courses compare to MOB (19), learning about self (12), learning about the kids (17), learning team and mentoring skills (17), learning about entrepreneurship (11), preparation for the world of work (14), and would recommend MOB to best friend (20).

The mentors' reflections in Table 14 also provide evidence about the effect of MOB on their personal and vocational development: MOB had a positive effect on their personal development (15) and on their likelihood of engaging in community service (16). MOB helped mentors to understand poverty (13) and helped them to appreciate cultural differences (12). MOB also shaped the mentor's career interests (7), their interest in starting a business (7), and their interest in working with kids (9).

Table 14: End-of Semester Mentor Journals - Impact on Personal and Vocational Development $(\mathrm{n}=24)$

\begin{tabular}{|l|c|l|}
\hline \multicolumn{1}{|c|}{$\begin{array}{l}\text { Impact on Development } \\
\text { MOB had a positive } \\
\text { impact on my } \\
\text { personal development }\end{array}$} & 15 & $\begin{array}{l}\text { ROB had a huge impact on me. It made me realize that there are more } \\
\text { important things in life than just money. }\end{array}$ \\
\cline { 3 - 4 } & $\begin{array}{l}\text { The impact this class had on me was tremendous. I learned to teach and } \\
\text { learned to listen. }\end{array}$ \\
\cline { 2 - 3 } & $\begin{array}{l}\text { In conclusion, I feel that MOB is the best thing that has happened to my life, } \\
\text { overall, in quite some time. The things I will take away from this class have } \\
\text { and will continue to change my life. }\end{array}$ \\
\hline
\end{tabular}




\begin{tabular}{|c|c|c|}
\hline \multicolumn{3}{|c|}{ Table 14: End-of Semester Mentor Journals - Impact on Personal and Vocational Development (n=24) } \\
\hline Impact on Development & \# & Reflections \\
\hline \multirow{3}{*}{$\begin{array}{l}\text { I am more likely to do } \\
\text { community } \\
\text { service }\end{array}$} & \multirow[t]{3}{*}{16} & $\begin{array}{l}\text { I can see myself doing community service that involves mentoring young } \\
\text { business students about the real world. }\end{array}$ \\
\hline & & $\begin{array}{l}\text { This class has made me feel good about my self for helping people less } \\
\text { fortunate than me and made me want to continue the work. }\end{array}$ \\
\hline & & $\begin{array}{l}\text { I definitely would do more community service because by being a role model } \\
\text { and a leader I can enhance the future of others and the community. }\end{array}$ \\
\hline \multirow{3}{*}{$\begin{array}{l}\text { MOB helped me } \\
\text { understand } \\
\text { poverty }\end{array}$} & \multirow[t]{3}{*}{$13^{1}$} & $\begin{array}{l}\text { I mean I had some views about poverty and such but I have now an } \\
\text { understanding about it, not just an idea. }\end{array}$ \\
\hline & & It made me realize that some people don't have it as easy as others... \\
\hline & & $\begin{array}{l}\text { There are many children in the program who are so smart and can go really } \\
\text { far but with poverty it will be hard for them to do it. }\end{array}$ \\
\hline \multirow{3}{*}{$\begin{array}{l}\text { MOB helped me } \\
\text { appreciate } \\
\text { cultural differences }\end{array}$} & \multirow[t]{3}{*}{$12^{2}$} & I learned to deal with children whose lives were so different from ${ }_{\text {mine. }}$ \\
\hline & & $\begin{array}{l}\text { I realized that I was dealing with different cultures and I have to adjust to } \\
\text { them. }\end{array}$ \\
\hline & & My views were naturally skewed when I came into the program. \\
\hline \multirow[t]{2}{*}{$\begin{array}{l}\text { MOB shaped my career } \\
\text { interests }\end{array}$} & \multirow[t]{2}{*}{$7^{3}$} & $\begin{array}{l}\text { Yes this program did shape my future career interests because in the future I } \\
\text { do want to become a teacher for inner-city kids. }\end{array}$ \\
\hline & & $\begin{array}{l}\text { My life plans are still to own my own business, and MOB has helped me } \\
\text { realize that I cannot see myself doing anything else other than that. }\end{array}$ \\
\hline \multirow{2}{*}{$\begin{array}{l}\text { I am more interested in } \\
\text { starting } \\
\text { my own business }\end{array}$} & \multirow[t]{2}{*}{$7^{4}$} & This program inspired me to think about starting and running a business. \\
\hline & & $\begin{array}{l}\text { I am interested in starting my own business but at the same time, I want the } \\
\text { business to be a place that help kids or work with them. }\end{array}$ \\
\hline \multirow{2}{*}{$\begin{array}{l}\text { I am more interested in } \\
\text { working } \\
\text { with kids }\end{array}$} & \multirow[t]{2}{*}{$9^{5}$} & I can see my future life filled with kids and me making them successful. \\
\hline & & $\begin{array}{l}\text { In the future I would definitely like to work more with kids at some point, } \\
\text { whether in coaching or teaching or mentoring, the experience you get from } \\
\text { kids is like none other. }\end{array}$ \\
\hline Total Reflections & 81 & \\
\hline \multicolumn{3}{|c|}{$\begin{array}{l}{ }^{1} \text { Two other mentors stated that they already had an idea of what poverty was like. A third mentor saw pover } \\
\text { an extenuating circumstance. } \\
{ }^{2} \text { Two other mentors wrote that they were already aware of cultural differences before they joined the progra } \\
{ }^{3} \text { One other mentor indicated that: "The program did not affect my career interests in any way because I am } \\
\text { looking to go into financial sales." }\end{array}$} \\
\hline
\end{tabular}




\section{DISCUSSION}

\section{MOB Effect on Middle-School Students}

The student, mentor, and partner school homeroom teacher surveys provide evidence of positive developmental changes taking place in MOB students during the program. The convergence of these three different perspectives on how well the program is working for the students adds validity to the findings. These assessments provide support for student development in terms of changes in self and improvement of important work/life skills: entrepreneurship, leadership, team and communication skills.

Student self-report measures indicate a greater interest in a career in entrepreneurship, starting their own businesses, going to college, and joining the Summer Program because of MOB. The student enjoyment of the team experience and the process of starting and running a business likely contributed to the students increased interest in entrepreneurship. In addition, mentors were also acting as role models who are worthy of emulation by their students. The mentors, many of whom are interested in starting their own businesses after graduation, may have had a positive influence on the students' future plans to start their own businesses and go to college.

Academic record data were one type of measure used to evaluate the MOB program effect on academic achievement and attendance/punctuality to school. The analyses of these data indicate that MOB appeared to have no short-term effect on students' GPA. This finding is consistent with homeroom teachers' observations that MOB students' experienced some improvement in their attendance but not in their overall grades.

In terms of attendance and punctuality, it appears that a winding-down effect on student effort exists at the partner school among all students. Absenteeism and tardiness worsen as the year progresses from one marking period to the next. In spite of this winding-down effect affecting all students, the effect of the MOB program on students is favorable, as compared to the control group, in terms of reducing absences and tardiness to school. There are several possible reasons for this effect. First, MOB students develop a habit of attending and being punctual to MOB program sessions that appears to transfer to their school participation after completing the program. Second, MOB students have the opportunity to interact and bond with other students as part of a team which also may increase their sense of connection and involvement to the school, and consequently improve attendance and punctuality. Finally, MOB students' reported increased interest in going to college may also lead to their placing an increased importance on going to school everyday.

\section{MOB Effect on Mentors}

Several studies have found that programs that provide more opportunities for reflection, substantive links between coursework and service, and ethical/cultural diversity have a stronger 
impact on service learners (Eyler \& Giles, 1999; Mabry, 1998; Gray et al, 1996). MOB seems to fit this successful program profile. Its effect on mentors' personal and vocational development is significant.

The end-of-semester mentor survey data provides evidence about MOB favorably influencing mentors' vocational interests. The majority of the mentors plan to do more community service and express a greater interest in working with kids in the future. Mentors clearly express an increased desire to include service to others in their career plans. A significant number of mentors also reported a greater desire to start their own businesses because of MOB. Through participation in the program mentors sample the process of starting and running a small business with their students which may increase their interest in entrepreneurship as a career.

The richness of the learning experience is best captured in the mentors' end of semester reflections. Mentors' reflections provide evidence of a great learning experience and of the positive impact of MOB on their personal and vocational development. Clearly, the most significant aspect of the learning experience, and the most memorable, was the field experience. This is where most of the challenges to development were found. The class and training portions of the course appeared to provide the necessary support for mentors to successfully meet the challenges that they faced in the field.

The key findings of this study provide evidence of reciprocity in the service-learning experience. Both the students and the mentors were positively effected in their personal and vocational development. This service-learning experience appeared to be a win-win situation for both the server and the served, where both mentors and students shared in a great learning experience. In this sense, MOB is a model of service-learning for others to emulate.

\section{LIMITATIONS}

A limitation of the current study is the qualitative nature of the end of semester mentor journals as a measure of program impact on mentors. While journaling is a valuable tool for evaluating the personal impact of such a program on mentors, these data are more problematic for coders to synthesize than are quantitative data. In addition, the measurement of effects on middle school students primarily through observation and secondary data is also open to questions of validity. This concern, however, is partially addressed by the effort on the part of the research to employ multiple measures to achieve triangulation. Finally, the case study nature of the research reported in this paper limits the external validity of the study and the generalization of its findings to other service-learning situations. 


\section{FUTURE RESEARCH}

The research plan is to conduct focus groups and surveys of MOB alumni (1997-2003) to be used for evaluating the long term program/course effects on both students and mentors. The purpose of the focus groups is to generate insights into the long-term impacts of the program/course on alumni and to generate information helpful in structuring two alumni questionnaires - one for the students and one for the mentors. Long-term effects to be addressed by the student alumni survey include whether students finished high school, decided to go to college, and continue to run their businesses. The mentor alumni survey will assess the long-term effect on the mentors' careers and the role that community service plays in their lives.

\section{REFERENCES}

College of Business Administration (2001). Student handbook. Lawrenceville, NJ: Collegiate Press.

Bacon, D. R., Stewart K. A. \& Stewart-Belle, S. (1998). Exploring predictors of student team project performance. Journal of Marketing Education, 20, 63-72.

Bloom, B. S. (1956). Taxonomy of educational objectives: The classification of educational goals. New York: David McKay.

Carnegie Council on Adolescent Development (1995). Great transitions: Preparing adolescents for a new century. New York: Carnegie Corporation.

Daloz, L. (1999). Mentor. San Francisco: Jossey-Bass.

Eyler, J., Giles, D.E., \& Schmiede, A. (1996). A practioner's guide to reflection in service learning: Student voices and reflections. Nashville: Vanderbilt University.

Eyler,J., \& Giles, D. E. (1999). Where's the learning in service-learning. San Francisco: Jossey-Bass.

Fiechtner, S. B. \& Davis, E. A. (1985). Why groups fail: A survey of student experiences with learning groups. Organizational Behavior Teaching Review, 9 (4), 58-73.

Godfrey, P. C. (2000). A moral argument for service-learning in management education. In P.C. Godfrey and E. T. Grasso (Eds.), Working for the common good: Concepts and models for service-learning in management. (pp. 21-42). Washington, D.C.: American Association for Higher Education.

Gray, M., Geshwind, S. A., Ondaatje, E., Robyn, A., Klien, S., Sax, L., Astin, A., \& Astin, H. (1996). Evaluation of learn and serve America, higher education: First year report, 1, Los Angeles: Higher Education Research Institute, UCLA.

Journal of Entrepreneurship Education, Volume 9, 2006 
Hamner, D.M. (2002). Building bridges: The Allyn \& Bacon student guide to service-learning. Boston: Allyn \& Bacon.

Howard, J. (2001). Academic service-learning: Myths, challenges, and recommendations. Teaching Excellence, 12 (3).

Jacoby, B. (1996). Service-learning in today's higher education. In B. Jacoby (Ed.), Service-learning in higher education. (pp. 3-25). San Francisco: Jossey-Bass.

Kendall, J. C. (1990). Combining service and learning: An introduction. In J.C. Kendall (Ed.), Combining service and learning: A resource book for community and public service. Raleigh, NC: National Society for Experiential Education.

Mabry,J.B. (1998). Pedagogical variations in service-learning and student outcomes: How time, contact and reflection matter. Michigan Journal of Community Service Learning, 3, 44-54.

Michaelsen, L. K. (1994). Classroom organization and management: Making a case for the small group option. In K.W. Prichard \& R. M. Sawyer (Eds.). Handbook of college teaching: Theory and application. Westport, CT: Greenwood.

Michaelsen, L. K. \& Black, R. H. (1994). Building learning teams: The key to harnessing the power of small groups in higher education. In S. Kadel \& J. Keehner (Eds.), Collaborative learning: A sourcebook for higher education. State College, PA: National Center for Teaching, Learning and Assessment.

Mintz, S. D. \& Hesser, G. W. (1996). Principles of good practice in service-learning. In B. Jacoby (Ed.), Servicelearning in higher education. (pp. 26-52). San Francisco: Jossey-Bass.

Morton, K. \& Troppe, M. (1996). From the margin to the mainstream: Campus compact's project of integrating service with academic study. Journal of Business Ethics, 15, 21-32.

Princeton Center for Leadership Training (1997). Minding our business: Team mentor advisor handbook. Princeton, NJ: PCLT.

Tuckman, B. \& Jensen, M. (1977). Stages of small group development revisited. Group and Organizational Studies, 2, 419-427.

Zlotkowski, E. (1998). Introduction: A new model of excellence. In Successful Service-Learning Programs: New Models of Excellence in Higher Education, E. Zlotkowski (Ed.). Bolton, MA: Anker Publishing Company, Inc. 


\title{
ECONOMIC KNOWLEDGE AND ENTREPRENEURIAL DISPOSITIONS IN ELEMENTARY STUDENTS: THE ENTREPRENEURS IN KENTUCKY INITIATIVE
}

\author{
Kimberly P. Code, Northern Kentucky University
}

\begin{abstract}
Entrepreneurship education has received increased attention at all levels of education. National content standards for entrepreneurship education have been developed that address content knowledge and attitudinal dispositions at elementary, middle, high school, and university levels. The current generation of students has even been referred to as the "Entrepreneurship Generation" (Kourilsky, 1995). In conjunction with this increased focus, one initiative that addressed the need for entrepreneurial and economic education at the elementary level was the Kentucky Council on Economic Education's Entrepreneurs in Kentucky curriculum program. This initiative aimed to develop economic and entrepreneurial knowledge and positive attitudinal dispositions in elementary students.

This paper presents the dispositional and content knowledge results of students from 13 elementary schools, a total of 300 students, who participated in the initial Entrepreneurs in Kentucky curriculum initiative. Student responses to the project's pretest and posttest instrument were analyzed to examine if there was a significant difference between the mean pretest and posttest scores for student dispositions toward, and knowledge of, economic and entrepreneurial content. Results from the study indicate that there was a significant increase in elementary student knowledge and improvement in attitudinal dispositions related to economic and entrepreneurial concepts as a result of their participation in the elementary program.
\end{abstract}

\section{INTRODUCTION}

The importance of the entrepreneur in our economy cannot be overestimated. Schumpeter defined entrepreneurship as the primary engine of economic development (McGraw, 1991). Samuelson and Nordhaus stated, "a country cannot thrive without [a group of entrepreneurs] willing to undertake risks, open new businesses, adopt new technologies, and import new ways of doing business" (2001). Finally, Clayton defined the entrepreneur's role as "an agent of change [that] qualifies him or her as being a key to economic growth" (2005). The entrepreneurial activity prevalence rate in the United States is 12.7 percent - the third highest among Global Entrepreneurship Monitor 2000 countries behind only Brazil and Korea (Zacharakis, Bygrave, \& Shepherd, 2000). 
Entrepreneurial companies make up only a small portion of all American companies and small percentages of new businesses started every year, but these companies play a crucial role in terms of creating jobs and stimulating the economy. America must "innovate or abdicate" (Kogan, 2005). The National Commission on Entrepreneurship notes that while entrepreneurial companies account for only six percent of the six million employees in the United States, these companies were responsible for approximately 65 percent of new jobs created from 1993-1996 (2002). It is estimated that in the United States, one in every 14 adults, or slightly more than seven percent, has invested in a start-up company. Each year Americans start 600,000 to 800,000 businesses with employees and about 2 million Americans start their own self-employment ventures. These business starts are the foundation of an entrepreneurial economy (National Commission on Entrepreneurship, 2006).

Research commissioned by the Kauffman Center for Entrepreneurial Leadership found that the United States leads the world in the awareness and desirability of entrepreneurship. Entrepreneurs are viewed as role models; failure is accepted as being a learning experience; and many view entrepreneurship as a career path with a great deal of potential. The six factors the study found to be most important in fostering successful entrepreneurial activities are: entrepreneurial opportunity, entrepreneurial capacity, infrastructure, demography, education, and culture (Zacharakis, Bygrave, \& Shepherd, 2000). In addition, consumers benefit from entrepreneurs. Entrepreneurs create new jobs that improve the quality of life and our position in the global economy. Entrepreneurs transform inventions and improve products and services. Even during times of recession, small and new businesses in the United States increased in size and number of jobs, while larger, more established companies downsized (Drucker, 2006).

A review of the literature shows that entrepreneurs - risk takers who undertake new business ventures in search of a profit - are an important component of the modern economy. Consequently, entrepreneurship education has become increasingly important for students at the elementary, middle, and high school levels. Entrepreneurship education is also important in the minority community, and women are a growing and significant component of the entrepreneurial movement. This importance has led to the infusion of economic and entrepreneurship education at the K-12 level - a development recognized by educators, business leaders, and politicians alike. Entrepreneurial education has grown from its original roots as a "start your own business" activity, to an understanding of economic concepts and the entrepreneur's role in the broader context of the overall economic system.

Since the early 1980s, there has been an increase in the number of courses and programs dedicated to economics and entrepreneurship (Block \& Stumpf, 1992; Gartner \& Vesper, 1993; Mangan, 2004). Research from the past two decades has provided evidence that students at the K-12 level are capable of learning economic concepts (Laney, 1990; Morgan, 1991). American adults have a strong interest in economics, and more than seven in ten indicate they have the same high level of interest in economics as they do in business, finance, and politics (Louis Harris \& 
Associates, 1999). Knowledge of economics and entrepreneurial concepts can aid students to make better career and consumer choices. It can also provide an understanding of how investment in human capital can benefit them throughout their lives (Clayton, 2005).

At the federal level there has also been an interest in creating opportunities for students to learn economic and entrepreneurial skills related to entrance into the workforce. The Partnership for $21^{\text {st }}$ Century Skills defined competencies and foundations that are essential for entering the workplace or higher education. It included competencies such as basic skills to read, write, compute, listen, and speak; thinking skills to enable students to create, decide, solve, envision, learn, and reason; and the personal qualities of responsibility, self-esteem, sociability, self-management, and integrity. These are all real-world competencies that can be addressed through successful entrepreneurial and economic education efforts (2006).

Former Federal Reserve Chairman Alan Greenspan emphasized that, "businesses are looking for employees who are prepared to continue learning, and who recognize that maintaining their human capital will require persistent hard work and flexibility" (1999). One way in which many experts believe the overall quality of education can be improved is by introducing entrepreneurship and economic education at the primary and secondary levels (Kent, 1990; Koon, 1990; Kourilsky, 1995). Formalizing some exposure in high school or earlier educational level should also be considered (Zacharakis, Bygrave, \& Shepherd, 2000).

Recently, Louis Harris and Associates, Inc. conducted The Standards in Economics Survey on behalf of the National Council on Economic Education. This national survey was designed to evaluate adult and student understanding of basic economic principles, knowledge about the U.S. economy, and familiarity with basic economic principles. The results of the study indicated that students and adults lacked a basic understanding of the core economic concepts of scarcity of resources, money, and inflation-with less than 50 percent of those surveyed demonstrating knowledge of these terms. Approximately three out of four, or 76 percent of surveyed American adults, compared with three out of five, or 58 percent of surveyed high school students, were aware that a person who starts a business to produce a new product in the marketplace is known as an entrepreneur. One in four, or 26 percent of surveyed students, did not know whether someone who starts a business to produce a new product in the marketplace is a manager, a bureaucrat, or an entrepreneur (Louis Harris \& Associates, 1999).

Research by Hatten and Ruhland demonstrated that identifying and nurturing entrepreneurs throughout the educational process could produce more successful entrepreneurs (1995). Although one cannot undeniably state that "educated entrepreneurs" will be better entrepreneurs because they studied entrepreneurship, there are strong indications that an entrepreneurial education will produce more and better-skilled entrepreneurs than there have been in the past, and that education enhances the chances for entrepreneurial success (Nakkula, 2004). 


\section{FACTORS AFFECTING STUDENT KNOWLEDGE AND ATTITUDINAL DISPOSITIONS}

Student attitudinal dispositions toward the content studied; background knowledge and experiences; prior exposure; age; gender; psychological characteristics; and the family environment have been shown to have an effect on student learning (Stiggins 1994; Krueger, 1993; Sosin, Dick \& Reiser, 1997; Nakkula, 2004). Entrepreneurship and economic education are no exception. Economists and entrepreneurship educators are interested in analyzing the link between teaching inputs (students' level of prior exposure and grade level, etc.) and learning outputs (knowledge and attitudinal dispositions) in order to understand how these factors may assist in improving students' understanding of, and interests in, economics (Becker, 1997; Walstad \& Soper, 1989).

One's environment and prior exposure to economics and entrepreneurial concepts and content can influence a student's dispositions toward the content being studied, including the content areas of economics and entrepreneurship. For example, Brickell and Scott noted that as student knowledge about a particular field of study increases, a change in student attitudinal dispositions usually occurs (Brickell \& Scott, 1976). This dispositional change can be particularly important at the elementary level as the development of positive dispositions can establish the foundation for future learning in the subject and possibly contribute to increased understanding and learning (Walstad, 1980). Another study showed that students' prior knowledge of economics, their gender, their compatibility with the teaching environment, and their level of effort were statistically significant (Becker, 1997).

Other researchers found that students from entrepreneurial families have a more favorable disposition toward entrepreneurship than those from nonentrepreneurial backgrounds (Brockhaus \& Horwitz, 1986; Brush, 1992; Cooper, 1986; Krueger, 1993). A broad-based study of 685 elementary students with prior exposure to economic and entrepreneurial concepts through participation in the Yes! /Mini-Society program found that persistence, academic ability, and creativity were important entrepreneurial characteristics of students participating in a simulated economy (Kourilsky, 1995). Ede, Bhagaban, and Calcich's surveyed student attitudinal dispositions toward entrepreneurship education using students who had prior exposure to economics and entrepreneurial content. Students from entrepreneurial families had a more positive disposition towards entrepreneurship. The study also indicated the need for "entrepreneurial interaction and mentoring in all aspects of the entrepreneurial curriculum - it cannot be left to experiences outside of course work no matter how appropriate they are in their own right" (1998).

\section{THE ENTREPRENEURS IN KENTUCKY INITIATIVE}

The Entrepreneurs in Kentucky curricular initiative was developed in a collaborative tradition to develop and implement an effective entrepreneurial and economic education program. 
As a result, there was the expectation that students would benefit by having a richer understanding of the importance of the entrepreneur in our economy. The evaluation phase of the program, and the focus of this paper, was intended to determine the success of the program, especially with respect to the attitudinal dispositions and knowledge of students, which is a fundamental ingredient to a successful entrepreneurial and economic education program.

The philosophy driving the Entrepreneurs in Kentucky initiative was to teach about economics, entrepreneurs, and entrepreneurship through the study of Kentucky entrepreneurs. The core of the elementary curriculum consisted of 10 lessons focusing on various aspects of entrepreneurial activity. Each of these 10 lessons contained links to national and state curriculum standards, teaching activities, community connections, curricular connections, teacher resources, and related web sites. Reproducible black-line activity sheets were available for each lesson. The elementary curriculum also contained written profiles of Kentucky entrepreneurs, a video developed by Kentucky Education Television, and a pretest and posttest for student assessment. The lessons developed student content knowledge and attitudinal dispositions focused on entrepreneurial characteristics such as innovation, risk, profit motives, problem solving, vision, adaptability, competitiveness, perseverance, and honesty. Specific economic concepts related to entrepreneurs included competition, the profit motive, innovation, opportunity cost, and the forms of business organization.

After receiving the training and implementing the curriculum in their individual classrooms, participating teachers were asked to administer copies of the 20 -question pretest and posttest to their students for assessment purposes. The tests contained questions that measured student attitudinal dispositions pertaining to their own entrepreneurial abilities, as well as the students' content knowledge about the role and importance of the entrepreneur in our economy. The pretest was administered before any of the lessons in the curriculum were taught, and then re-administered after the lessons were conducted. Participating teachers submitted the student tests along with a cover sheet that identified the grade level, school district and school name, lessons taught, and students' prior exposure to economic and entrepreneurial concepts.

\section{METHODOLOGY}

Approximately 300 students from 13 Kentucky elementary schools participated in this initial assessment of the Entrepreneurs in Kentucky curricular initiative. The assessment document is located in the Appendix. At the elementary curriculum level, two research questions were posed for statistical analysis. These research questions treat the mean student scores for each of the seven bi-polar adjective attitudinal disposition questions, as well as the scores for the 10 multiple-choice knowledge/content questions on the student assessment instrument, as dependent variables. The independent variables were the elementary students' prior exposure to economic and entrepreneurial concepts and the individual elementary students' grade levels. 
The data was analyzed using a t-test with a pooled estimate of population standard deviation to determine the significance of the difference between the mean pretest and posttest scores. The t-test was used to determine if the difference in the sample means for knowledge as well as dispositions (pretest scores and posttest scores) can be attributed to the influence of student participation in the Entrepreneurs in Kentucky initiative, or if the difference could have happened by chance. In addition, a single factor ANOVA was also used to determine the influence of the independent variables on the students' posttest scores.

\section{STATISTICAL RESULTS AND INTERPRETATION}

\section{Change in Elementary Student Dispositions}

The results of the t-test analyses presented in Table 1 shows that, at the elementary curriculum level, students had significant changes in attitudinal dispositions on four of the eight questions (also see Appendix). At the 95\% significance level, student scores were significantly different on question five with the mean of posttest scores moving toward the "hard work" end of the semantic response scale. At the $99 \%$ significance level, mean student scores were significantly different on question three, with posttest scores moving toward the "like to be" end of the response scale; on question six, with posttest scores moving toward the "good" end of the response scale; and on question eight, with posttest scores moving toward the "more" end of the response scale. Responses for questions four, seven, nine, and 10 showed no significant changes in student dispositions.

\begin{tabular}{|c|c|c|}
\hline Dispositional Questions and Responses & & Elementary \\
\hline $\begin{array}{l}\text { 3. I would } \_ \text {an entrepreneur. } \\
\qquad \text { like to be ........never want to be }\end{array}$ & $\begin{array}{c}\text { Pretest } \\
\text { Posttest } \\
\text { Sig. Level }\end{array}$ & $\begin{array}{l}4.29 \\
3.36 \\
\leftarrow \leftarrow\end{array}$ \\
\hline $\begin{array}{l}\text { 4. I think that it would be } \_ \text {to study about entrepreneurs. } \\
\text { fun } \ldots \ldots \ldots \text { boring }\end{array}$ & $\begin{array}{c}\text { Pretest } \\
\text { Posttest } \\
\text { Sig. Level }\end{array}$ & $\begin{array}{l}4.02 \\
3.26\end{array}$ \\
\hline $\begin{array}{l}\text { 5. Being an entrepreneur would be } \\
\text { hard work } \ldots \ldots \ldots \text { easy }\end{array}$ & $\begin{array}{c}\text { Pretest } \\
\text { Posttest } \\
\text { Sig. Level }\end{array}$ & $\begin{array}{c}3.14 \\
2.42 \\
\leftarrow\end{array}$ \\
\hline $\begin{array}{l}\text { 6. I think that entrepreneurs are ___ for our state and community. } \\
\text { bad } \ldots \ldots \ldots \text { good }\end{array}$ & $\begin{array}{c}\text { Pretest } \\
\text { Posttest } \\
\text { Sig. Level }\end{array}$ & $\begin{array}{l}4.89 \\
6.32 \\
\rightarrow \rightarrow\end{array}$ \\
\hline $\begin{array}{l}\text { 7. Personally, I know } \_ \text {entrepreneurs. } \\
\text { many } \ldots \ldots \ldots \text { few }\end{array}$ & $\begin{array}{c}\text { Pretest } \\
\text { Posttest } \\
\text { Sig. Level }\end{array}$ & $\begin{array}{l}5.81 \\
5.64\end{array}$ \\
\hline
\end{tabular}




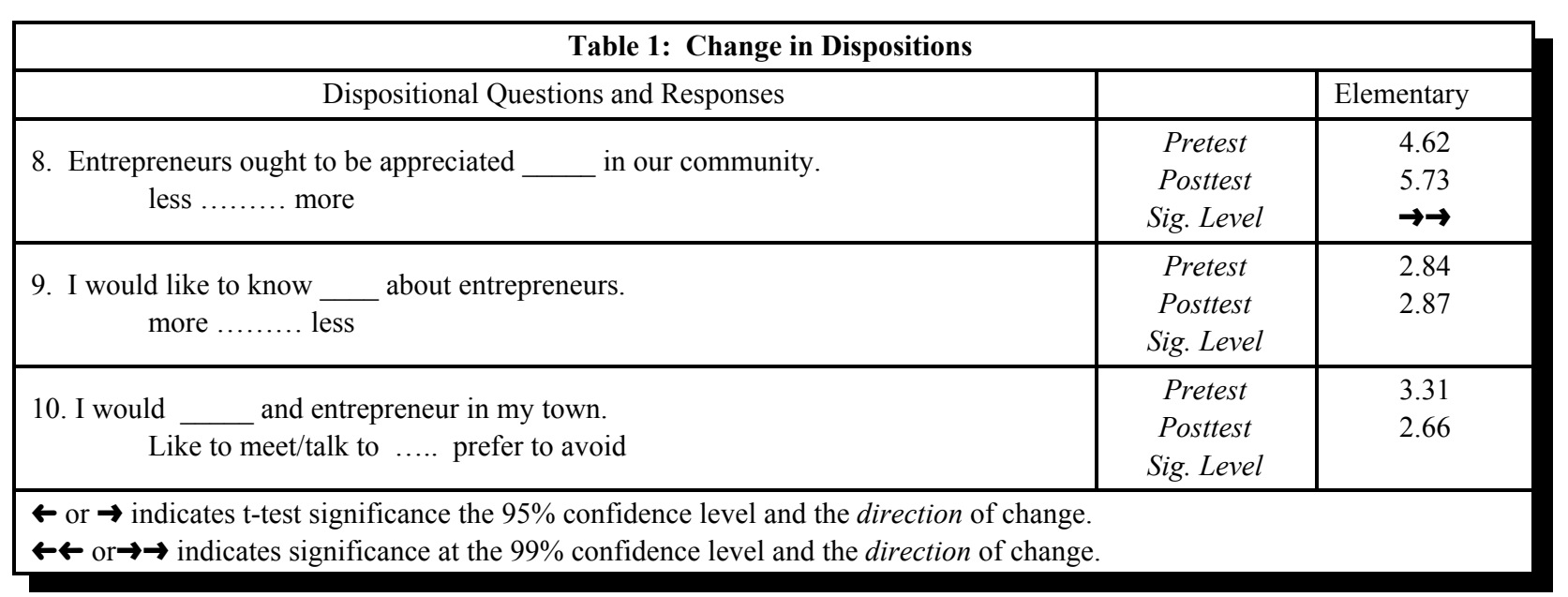

\section{Change in Elementary Student Economic and Entrepreneurial Knowledge}

\section{t-test statistic}

The results of the t-test analyses presented in Table 2 show that the elementary students scored significantly higher on all 10 questions related to knowledge of entrepreneurial and economic concepts. In fact, all scores were statistically significant at the $99 \%$ level for the elementary initiative. The assessed content included concepts such as the forms of business organization (proprietorship, partnership, and corporation), a general description of the entrepreneur and the entrepreneurial work environment, the entrepreneur's profit motive, the nature and role of productive resources, and the role and importance of the entrepreneur in the community. In addition, the assessed economic and entrepreneurial content included the primary motivation of the entrepreneur, the workings of a market economy, and the role and importance of the forces of supply and demand.

\begin{tabular}{|c|c|c|}
\hline Content Questions & & Mean Student Scores \\
\hline 11 & $\begin{array}{c}\text { Pretest } \\
\text { Posttest } \\
\text { Sig. Level }\end{array}$ & $\begin{array}{l}0.35 \\
0.82 \\
\text { 仓ิ }\end{array}$ \\
\hline 12 & $\begin{array}{c}\text { Pretest } \\
\text { Posttest } \\
\text { Sig. Level }\end{array}$ & $\begin{array}{l}0.37 \\
0.91 \\
\text { 仓ิ 仑̂ }\end{array}$ \\
\hline 13 & $\begin{array}{c}\text { Pretest } \\
\text { Posttest } \\
\text { Sig. Level }\end{array}$ & $\begin{array}{l}0.26 \\
0.46 \\
\text { 仓ิि }\end{array}$ \\
\hline
\end{tabular}




\begin{tabular}{|c|c|c|}
\hline Content Questions & & Mean Student Scores \\
\hline 14 & $\begin{array}{c}\text { Pretest } \\
\text { Posttest } \\
\text { Sig. Level }\end{array}$ & $\begin{array}{l}0.28 \\
0.76 \\
\text { 仓ิ }\end{array}$ \\
\hline 15 & $\begin{array}{c}\text { Pretest } \\
\text { Posttest } \\
\text { Sig. Level }\end{array}$ & $\begin{array}{l}0.42 \\
0.87 \\
\text { 仓ิ }\end{array}$ \\
\hline 16 & $\begin{array}{c}\text { Pretest } \\
\text { Posttest } \\
\text { Sig. Level }\end{array}$ & $\begin{array}{l}0.41 \\
0.69 \\
\text { 仓ิ仑 }\end{array}$ \\
\hline 17 & $\begin{array}{c}\text { Pretest } \\
\text { Posttest } \\
\text { Sig. Level }\end{array}$ & $\begin{array}{l}0.40 \\
0.66 \\
\text { 仓ิ仑 }\end{array}$ \\
\hline 18 & $\begin{array}{c}\text { Pretest } \\
\text { Posttest } \\
\text { Sig. Level }\end{array}$ & $\begin{array}{l}0.51 \\
0.85 \\
\text { 仑ิ仑 }\end{array}$ \\
\hline 19 & $\begin{array}{c}\text { Pretest } \\
\text { Posttest } \\
\text { Sig. Level }\end{array}$ & $\begin{array}{l}0.50 \\
0.76 \\
\text { 仓ิ }\end{array}$ \\
\hline 20 & $\begin{array}{c}\text { Pretest } \\
\text { Posttest } \\
\text { Sig. Level }\end{array}$ & $\begin{array}{l}0.39 \\
0.72 \\
\text { 仓ิ仑 }\end{array}$ \\
\hline Mean 11-20 & $\begin{array}{c}\text { Pretest } \\
\text { Posttest } \\
\text { Sig. Level }\end{array}$ & $\begin{array}{l}3.57 \\
7.31 \\
\text { 仓ิ }\end{array}$ \\
\hline
\end{tabular}

\section{STRATIFICATION OF RESULTS BY PRIOR EXPOSURE TO ECONOMIC AND ENTREPRENEURIAL CONTENT}

Research question one was designed to determine if there was a significant difference between the mean pretest and posttest scores for attitudinal dispositions and economic concepts when students were stratified by prior exposure to economic and entrepreneurial concepts. This section examines the research question with the use of the t-test and a one-way analysis of variance at the $95 \%$ level of significance.

\section{Prior Exposure, Change in Dispositions}

The results of the t-test analyses presented in Table 3 shows that, of the 24 possible outcomes, three were statistically significant at the $95 \%$ level, four were significant at the $99 \%$ level, and 17 showed no significant change. Question eight showed statistically significant results for all 
the prior exposure groups being analyzed. Because the dispositional questions measure different economic and entrepreneurial constructs (such as beliefs and preferences), they will not be combined for a mean dispositional score. For example, it would be meaningless to add the scores for question three, "I would like to be/never want to be an entrepreneur," with question seven, "Personally, I know many/few entrepreneurs."

Those students whose teachers indicated that they had more than average exposure to economics and/or entrepreneurial concepts had significant changes in dispositions on two of the eight questions. At the $95 \%$ significance level, student scores were significantly different on question three, with the mean posttest scores moving toward the "like to be" end of the semantic response scale. At the $99 \%$ significance level, mean student scores were significantly different on question eight, with posttest scores moving toward the "more" end of the response scale. Responses for questions four, five, six, seven, nine, and 10 showed no significant changes in student dispositions.

Those students whose teachers indicated that they had average exposure to economics and/or entrepreneurial concepts had significant changes in dispositions on two of the eight questions. At the $95 \%$ significance level, mean student scores were significantly different on question eight, with posttest scores moving toward "more." At the 99\% significance level, mean student scores were significantly different on question six, with posttest scores moving closer to the "good" end of the response scale. Responses for questions three, four, five, seven, nine, and 10 showed no significant changes in student dispositions between pretest and posttest scores.

Those elementary level students whose teachers indicated that they had no exposure at all to economics and/or entrepreneurial concepts had significant changes in dispositions on three of the eight questions. At the $95 \%$ significance level, mean student scores were significantly different on question five, with mean posttest scores moving closer toward the "hard work" end of the response scale. At the $99 \%$ significance level, mean student scores were significantly different on question six, with mean posttest scores moving closer toward "good," and question eight with mean posttest scores moving toward "more." Responses for questions three, four, seven, nine, and 10 showed no significant changes in student dispositions.

\begin{tabular}{|c|c|c|c|c|}
\hline Dispositional Questions and Responses & & $\begin{array}{c}\text { No } \\
\text { Exposure }\end{array}$ & $\begin{array}{l}\text { Average } \\
\text { Exposure }\end{array}$ & $\begin{array}{c}\text { More than } \\
\text { Average }\end{array}$ \\
\hline $\begin{array}{l}\text { 3. I would } \_ \text {an entrepreneur. } \\
\qquad \text { like to be .........never want to be }\end{array}$ & $\begin{array}{l}\text { Pretest } \\
\text { Posttest } \\
\text { Sig. Level }\end{array}$ & $\begin{array}{l}4.24 \\
3.36\end{array}$ & $\begin{array}{l}4.34 \\
3.63\end{array}$ & $\begin{array}{l}4.82 \\
3.17 \\
\leftarrow\end{array}$ \\
\hline $\begin{array}{l}\text { 4. I think that it would be ___ to study about } \\
\text { entrepreneurs. } \\
\text { Fun ........ boring }\end{array}$ & $\begin{array}{l}\text { Pretest } \\
\text { Posttest } \\
\text { Sig. Level }\end{array}$ & $\begin{array}{l}3.89 \\
3.08\end{array}$ & $\begin{array}{l}4.53 \\
3.72\end{array}$ & $\begin{array}{l}4.12 \\
3.28\end{array}$ \\
\hline $\begin{array}{c}\text { 5. Being an entrepreneur would be } \\
\text { hard work ........ easy }\end{array}$ & $\begin{array}{l}\text { Pretest } \\
\text { Posttest }\end{array}$ & $\begin{array}{l}3.18 \\
2.31\end{array}$ & $\begin{array}{l}3.04 \\
2.53\end{array}$ & $\begin{array}{l}2.42 \\
1.96\end{array}$ \\
\hline
\end{tabular}




\begin{tabular}{|c|c|c|c|c|}
\hline Dispositional Questions and Responses & & $\begin{array}{l}\text { No } \\
\text { Exposure }\end{array}$ & $\begin{array}{l}\text { Average } \\
\text { Exposure }\end{array}$ & $\begin{array}{l}\text { More than } \\
\text { Average }\end{array}$ \\
\hline & Sig. Level & $\leftarrow$ & & \\
\hline $\begin{array}{l}\text { 6. I think that entrepreneurs are ___ for our } \\
\text { state and community. } \\
\text { bad ......... good }\end{array}$ & $\begin{array}{l}\text { Pretest } \\
\text { Posttest } \\
\text { Sig. Level }\end{array}$ & $\begin{array}{l}4.68 \\
6.28 \\
\rightarrow \rightarrow\end{array}$ & $\begin{array}{l}4.87 \\
6.28 \\
\rightarrow \rightarrow\end{array}$ & $\begin{array}{l}5.06 \\
6.11\end{array}$ \\
\hline $\begin{array}{l}\text { 7. Personally, I know } \_ \text {entrepreneurs. } \\
\text { many } \ldots . . . \ldots \text { few }\end{array}$ & $\begin{array}{l}\text { Pretest } \\
\text { Posttest } \\
\text { Sig. Level }\end{array}$ & $\begin{array}{l}5.90 \\
5.70\end{array}$ & $\begin{array}{l}5.37 \\
5.60\end{array}$ & $\begin{array}{l}6.17 \\
6.02\end{array}$ \\
\hline $\begin{array}{l}\text { 8. Entrepreneurs ought to be appreciated ___ in } \\
\text { our community. } \\
\text { less ......... more }\end{array}$ & $\begin{array}{l}\text { Pretest } \\
\text { Posttest } \\
\text { Sig. Level }\end{array}$ & $\begin{array}{l}4.50 \\
5.61 \\
\rightarrow \rightarrow\end{array}$ & $\begin{array}{l}4.46 \\
5.48 \\
\rightarrow\end{array}$ & $\begin{array}{l}4.72 \\
6.04 \\
\rightarrow \rightarrow\end{array}$ \\
\hline $\begin{array}{l}\text { 9. I would like to know } \_ \text {about entrepreneurs. } \\
\text { more } \ldots \ldots \ldots \text { less }\end{array}$ & $\begin{array}{l}\text { Pretest } \\
\text { Posttest } \\
\text { Sig. Level }\end{array}$ & $\begin{array}{l}2.75 \\
2.92\end{array}$ & $\begin{array}{l}3.42 \\
3.08\end{array}$ & $\begin{array}{l}2.86 \\
2.49\end{array}$ \\
\hline $\begin{array}{l}\text { 10. I would } \\
\text { Like to meet/talk to ... prefer to avoid }\end{array}$ & $\begin{array}{l}\text { Pretest } \\
\text { Posttest } \\
\text { Sig. Level }\end{array}$ & $\begin{array}{l}3.27 \\
2.59\end{array}$ & $\begin{array}{l}3.96 \\
2.97\end{array}$ & $\begin{array}{l}3.15 \\
2.61\end{array}$ \\
\hline
\end{tabular}

\section{Prior Exposure, Change in Knowledge}

\section{t-test statistic}

The results of the t-test analyses presented in Table 4 show that of the 33 possible responses, two were statistically significant at the $95 \%$ level, 28 were statistically significant at the $99 \%$ level, and three showed no significant change. While there are no "right" or "wrong" answers for the dispositional questions, higher scores are better than lower scores for the content and knowledge questions $11-20$ shown in Table 4 . Those questions that were statistically significant for all of the prior exposure groups were question 11, "Entrepreneurs usually work for their own businesses;" question 12, "The entrepreneur receives profits as the reward for his or her activities;" question 15 , "An entrepreneur is a person who goes into business to make a profit;" question 16, "The entrepreneur typically works long hours, which often leaves little time for recreation and other activities;" question 17, "Entrepreneurs are found most often in all businesses, regardless of size or type of product produced;" question 19, "You give up an hour of math to study about entrepreneurs. The opportunity cost of studying entrepreneurs is the hour of math you gave up;" and, question 20, "An entrepreneur is motivated by the possibility of earning a profit." Finally, the mean content scores for questions 11 through 20 were statistically significant for all of the prior exposure groups at either the $95 \%$ or the $99 \%$ confidence levels. 
Those students whose teachers indicated that they had more than average exposure to economics and/or entrepreneurial concepts had significantly higher mean scores on seven of the 10 questions related to knowledge of economic and entrepreneurial concepts. At the $99 \%$ significance level, mean student scores were significantly higher on questions $11,12,15,16,17,19$, and 20. Responses for questions 13,14, and 18 showed no significant changes in student knowledge of economics and entrepreneurial content. At the 95\% significance level, student scores were significantly higher for the mean of questions 11 through 20 .

Those students whose teachers indicated that they had average exposure to economics and/or entrepreneurial concepts had significantly higher scores on all 10 questions related to knowledge of economic and entrepreneurial concepts. At the 95\% significance level, students scored significantly higher on question 13, "Three productive resources are people, capital goods, and natural resources." At the $99 \%$ significance level, students scored significantly higher on questions $11,12,14,15,16,17,18,19$, and 20. In addition, students with average exposure to economics and/or entrepreneurial concepts had significantly higher scores (at the $99 \%$ significance level) for the mean of questions 11 through 20 .

Those students whose teachers indicated that they had no exposure at all to economics and/or entrepreneurial concepts, scored significantly higher on all 10 questions related to knowledge of economic and entrepreneurial concepts. In fact, all scores were statistically significant at the 99\% level for the students in this group. The assessed content included concepts such as the forms of business organization (proprietorship, partnership, and corporation); a general description of the entrepreneur and the entrepreneurial work environment; the nature and role of productive resources; the role of the entrepreneur in the community; the primary motivation of the entrepreneur; the workings of a market economy; the nature of opportunity cost; and, the role and importance of the forces of supply and demand.

\begin{tabular}{|c|c|c|c|c|}
\hline Content Questions & & No Exposure & $\begin{array}{l}\text { Average } \\
\text { Exposure }\end{array}$ & $\begin{array}{c}\text { More than } \\
\text { Average }\end{array}$ \\
\hline 11 & $\begin{array}{c}\text { Pretest } \\
\text { Posttest } \\
\text { Sig. Level }\end{array}$ & $\begin{array}{l}0.35 \\
0.79 \\
\text { 仓ि }\end{array}$ & $\begin{array}{l}0.33 \\
0.73 \\
\text { 仓ิ }\end{array}$ & $\begin{array}{l}0.50 \\
0.93 \\
\text { 仓ิ }\end{array}$ \\
\hline 12 & $\begin{array}{c}\text { Pretest } \\
\text { Posttest } \\
\text { Sig. Level }\end{array}$ & $\begin{array}{l}0.34 \\
0.91 \\
\text { 仓ि }\end{array}$ & $\begin{array}{l}0.35 \\
0.92 \\
\text { 仓ि }\end{array}$ & $\begin{array}{l}0.59 \\
0.93 \\
\text { 仓ि }\end{array}$ \\
\hline 13 & $\begin{array}{c}\text { Pretest } \\
\text { Posttest } \\
\text { Sig. Level }\end{array}$ & $\begin{array}{l}0.17 \\
0.45 \\
\text { 仓仓 }\end{array}$ & $\begin{array}{c}0.41 \\
0.53 \\
\text { 仓 }\end{array}$ & $\begin{array}{l}0.55 \\
0.52\end{array}$ \\
\hline 14 & $\begin{array}{c}\text { Pretest } \\
\text { Posttest } \\
\text { Sig. Level }\end{array}$ & $\begin{array}{l}0.17 \\
0.77 \\
\text { 仓ิ }\end{array}$ & $\begin{array}{l}0.31 \\
0.78 \\
\text { 仓ิ }\end{array}$ & $\begin{array}{l}0.76 \\
0.76\end{array}$ \\
\hline
\end{tabular}




\begin{tabular}{|c|c|c|c|c|}
\hline Content Questions & & No Exposure & $\begin{array}{l}\text { Average } \\
\text { Exposure }\end{array}$ & $\begin{array}{c}\text { More than } \\
\text { Average }\end{array}$ \\
\hline 15 & $\begin{array}{c}\text { Pretest } \\
\text { Posttest } \\
\text { Sig. Level }\end{array}$ & $\begin{array}{l}0.44 \\
0.85 \\
\text { 仓仓 }\end{array}$ & $\begin{array}{l}0.31 \\
0.85 \\
\text { 仓仓 }\end{array}$ & $\begin{array}{l}0.45 \\
0.98 \\
\text { 仓ि }\end{array}$ \\
\hline 16 & $\begin{array}{c}\text { Pretest } \\
\text { Posttest } \\
\text { Sig. Level }\end{array}$ & $\begin{array}{l}0.36 \\
0.75 \\
\text { 仓ิ }\end{array}$ & $\begin{array}{l}0.46 \\
0.61 \\
\text { 仓ิ }\end{array}$ & $\begin{array}{l}0.53 \\
0.70 \\
\text { 仓ิ }\end{array}$ \\
\hline 17 & $\begin{array}{c}\text { Pretest } \\
\text { Posttest } \\
\text { Sig. Level }\end{array}$ & $\begin{array}{l}0.40 \\
0.64 \\
\text { 仓ิ }\end{array}$ & $\begin{array}{l}0.28 \\
0.63 \\
\text { 仓ิ }\end{array}$ & $\begin{array}{l}0.53 \\
0.80 \\
\text { 仓ิ }\end{array}$ \\
\hline 18 & $\begin{array}{c}\text { Pretest } \\
\text { Posttest } \\
\text { Sig. Level }\end{array}$ & $\begin{array}{l}0.54 \\
0.86 \\
\text { 仓ิ }\end{array}$ & $\begin{array}{l}0.21 \\
0.84 \\
\text { 仓ิ }\end{array}$ & $\begin{array}{l}0.67 \\
0.76\end{array}$ \\
\hline 19 & $\begin{array}{c}\text { Pretest } \\
\text { Posttest } \\
\text { Sig. Level }\end{array}$ & $\begin{array}{l}0.45 \\
0.75 \\
\text { 仓仓 }\end{array}$ & $\begin{array}{l}0.43 \\
0.79 \\
\text { 仓ิ }\end{array}$ & $\begin{array}{l}0.82 \\
0.89 \\
\text { 仓ิ }\end{array}$ \\
\hline 20 & $\begin{array}{c}\text { Pretest } \\
\text { Posttest } \\
\text { Sig. Level }\end{array}$ & $\begin{array}{l}0.36 \\
0.72 \\
\text { 仓仓 }\end{array}$ & $\begin{array}{l}0.41 \\
0.67 \\
\text { 仓ิ }\end{array}$ & $\begin{array}{l}0.54 \\
0.87 \\
\text { 仓ि }\end{array}$ \\
\hline Mean 11-20 & $\begin{array}{c}\text { Pretest } \\
\text { Posttest } \\
\text { Sig. Level }\end{array}$ & $\begin{array}{l}3.53 \\
7.41 \\
\text { 仓ि }\end{array}$ & $\begin{array}{l}2.51 \\
6.89 \\
\text { 仓ि }\end{array}$ & $\begin{array}{c}5.18 \\
7.89 \\
\text { 仓 }\end{array}$ \\
\hline
\end{tabular}

\section{ANOVA.}

The results of the one-way analysis of variance, presented in Table 5, show that there was a significant difference between the three groups (no exposure, average exposure, and more than average exposure) for both the pretests and the posttests. Specifically, the F-test statistic for the pretest means was 21.43, which is significant at the $99 \%$ level. Based on this outcome, the null hypothesis that there is no significant different between the dependent variable means is rejected. Alternatively, we could look at the P-value, which is the probability that the sample outcome could have generated a larger F-statistic than the 21.43 that was computed from the sample (Neter, et al, 1985). Since the confidence level is equal to 1 minus the $\mathrm{P}$-value, the results are significant at the 99\% level of confidence.

Likewise, the F-test statistic for the posttest means was 3.18, indicating a significance level of $95 \%$. Consequently, the results of the ANOVA in Table 5 indicate that the level of prior exposure is a significant independent variable, although the influence of the variable is more pronounced for the pretest than the posttest data. 


\begin{tabular}{|c|c|c|c|}
\hline Prior Exposure & $\begin{array}{l}\text { Pretest, Mean Score, } \\
\text { Questions 11-20 }\end{array}$ & $\begin{array}{l}\text { Posttest, Mean Score, } \\
\text { Questions 11-20 }\end{array}$ & $\begin{array}{c}\text { t-test Significance Level, Mean } \\
\text { Score, } \\
\text { Questions 11-20 }\end{array}$ \\
\hline More Than Average & 5.18 & 7.89 & 仓े \\
\hline Average Exposure & 2.51 & 6.89 & 仓仓 \\
\hline No Exposure & 3.53 & 7.41 & 仓仓 \\
\hline $\begin{array}{l}\text { F-Value } \\
\text { P-Value }\end{array}$ & $\begin{array}{c}21.43 \\
2.21 \mathrm{E}-09\end{array}$ & $\begin{array}{l}3.18 \\
0.04\end{array}$ & \\
\hline Significance Level & 仓仓 & 仓े & \\
\hline
\end{tabular}

\section{STRATIFICATION OF RESULTS BY GRADE LEVEL}

The second research question was designed to determine if there was a significant difference between elementary students' pretest and posttest scores for dispositions and economic concepts when responses were stratified by grade level. This section examines the research question with the use of the t-test and a one-way analysis of variance.

\section{Grade Level, Change in Dispositions}

The results of the t-test analyses presented in Table 6 show that of the 24 possible outcomes, three were statistically significant at the $95 \%$ level, three were statistically significant at the $99 \%$ level, and 18 showed no significant change. Question six was the only question that showed statistically significant results for all the grade level groups.

At the primary grade level, students had significant changes in dispositions on one of the eight questions. At the $95 \%$ significance level, student scores were significantly different on question six, with the mean of posttest scores moving toward the "good" end of the semantic response scale. Responses for questions three, four, five, seven, eight, nine, and 10 showed no significant changes in student dispositions. At the fourth grade level, students had significant changes in dispositions on one of the eight questions. At the $99 \%$ significance level, student scores were significantly different on question six, with the mean of posttest scores moving toward the "good" end of the semantic response scale. Responses for questions three, four, five, seven, eight, nine, and 10 showed no significant changes in student dispositions.

At the fifth grade level, students had significant changes in dispositions on four of the eight questions. At the $95 \%$ significance level, student scores were significantly different on question three, with the mean of the posttest scores moving toward the "like to be" end of the semantic 
response scale, and on question five, with the mean of posttest scores moving toward the "hard work" end of the response scale. At the $99 \%$ significance level, student scores were significantly different on question six, with the mean of the posttest scores moving toward the "good" end of the semantic response scale and question eight, with the mean of posttest scores moving toward the "more" end of the semantic response scale. Responses for questions four, seven, nine, and 10 showed no significant changes in student economic and entrepreneurial dispositions.

\begin{tabular}{|c|c|c|c|c|}
\hline Dispositional Questions and Responses & & Primary & Fourth & Fifth \\
\hline $\begin{array}{l}\text { 3. I would } \_ \text {an entrepreneur. } \\
\qquad \text { like to be ........never want to be }\end{array}$ & $\begin{array}{c}\text { Pretest } \\
\text { Posttest } \\
\text { Sig. Level }\end{array}$ & $\begin{array}{l}3.78 \\
3.04\end{array}$ & $\begin{array}{l}4.51 \\
3.29\end{array}$ & $\begin{array}{c}4.29 \\
3.39 \\
\diamond\end{array}$ \\
\hline $\begin{array}{l}\text { 4. I think that it would be ___ to study about } \\
\text { entrepreneurs. } \\
\text { Fun ......... boring }\end{array}$ & $\begin{array}{c}\text { Pretest } \\
\text { Posttest } \\
\text { Sig. Level }\end{array}$ & $\begin{array}{l}3.78 \\
3.18\end{array}$ & $\begin{array}{l}3.93 \\
3.00\end{array}$ & $\begin{array}{l}4.05 \\
3.33\end{array}$ \\
\hline $\begin{array}{c}\text { 5. Being an entrepreneur would be } \\
\text { hard work ........ easy }\end{array}$ & $\begin{array}{c}\text { Pretest } \\
\text { Posttest } \\
\text { Sig. Level }\end{array}$ & $\begin{array}{l}4.11 \\
3.61\end{array}$ & $\begin{array}{l}3.10 \\
2.14\end{array}$ & $\begin{array}{c}3.12 \\
2.29 \\
\diamond\end{array}$ \\
\hline $\begin{array}{l}\text { 6. I think that entrepreneurs are ___ for our state and } \\
\text { community. } \\
\text { bad ......... good }\end{array}$ & $\begin{array}{c}\text { Pretest } \\
\text { Posttest } \\
\text { Sig. Level }\end{array}$ & $\begin{array}{l}6.28 \\
6.96 \\
\Rightarrow\end{array}$ & $\begin{array}{l}4.96 \\
6.54 \\
\Rightarrow \Rightarrow\end{array}$ & $\begin{array}{l}4.58 \\
6.16 \\
\Rightarrow \Rightarrow\end{array}$ \\
\hline $\begin{array}{l}\text { 7. Personally, I know } \\
\text { many ......... few }\end{array}$ & $\begin{array}{c}\text { Pretest } \\
\text { Posttest } \\
\text { Sig. Level }\end{array}$ & $\begin{array}{l}5.56 \\
4.75\end{array}$ & $\begin{array}{l}5.71 \\
5.69\end{array}$ & $\begin{array}{l}5.92 \\
5.69\end{array}$ \\
\hline $\begin{array}{l}\text { 8. Entrepreneurs ought to be appreciated ___ in our } \\
\text { community. } \\
\text { less ......... more }\end{array}$ & $\begin{array}{c}\text { Pretest } \\
\text { Posttest } \\
\text { Sig. Level }\end{array}$ & $\begin{array}{l}5.56 \\
6.46\end{array}$ & $\begin{array}{l}4.77 \\
5.73\end{array}$ & $\begin{array}{l}4.37 \\
5.71 \\
\Rightarrow \Rightarrow\end{array}$ \\
\hline $\begin{array}{l}\text { 9. I would like to know } \\
\text { more } . . . . . . . \text { less }\end{array}$ & $\begin{array}{c}\text { Pretest } \\
\text { Posttest } \\
\text { Sig. Level }\end{array}$ & $\begin{array}{l}2.27 \\
2.79\end{array}$ & $\begin{array}{l}3.05 \\
2.90\end{array}$ & $\begin{array}{l}2.73 \\
2.86\end{array}$ \\
\hline $\begin{array}{l}\text { 10. I would } \_ \text {and entrepreneur in my town. } \\
\text { Like to meet/talk to ... prefer to avoid }\end{array}$ & $\begin{array}{c}\text { Pretest } \\
\text { Posttest } \\
\text { Sig. Level }\end{array}$ & $\begin{array}{l}2.56 \\
2.46\end{array}$ & $\begin{array}{l}3.21 \\
2.65\end{array}$ & $\begin{array}{l}3.40 \\
2.68\end{array}$ \\
\hline
\end{tabular}

\section{Grade Level, Change in Knowledge}

\section{t-test statistic}

The results of the t-test analyses presented in Table 7 show that of the 33 possible responses, none were statistically significant at the $95 \%$ level, 31 were statistically significant at the $99 \%$ level, 
and two showed no significant change. Those questions that were statistically significant for all of the grade levels were questions $11,12,13,14,15,17,18$, and 20. In addition, the mean content scores for questions 11 through 20 were statistically significant for all of the grade level groups.

Students at the primary grade levels scored significantly higher on eight of the 10 questions related to knowledge of economic and entrepreneurial concepts. At the $99 \%$ significance level, students had significantly higher mean scores on questions 11, 12, 13, 14, 15, 17, 18, and 20. Responses for question 16, "The entrepreneur typically works long hours, which often leaves little time for recreation and other activities" and question 19, "You give up an hour of math to study about entrepreneurs. The opportunity cost of studying entrepreneurs is the hour of math you gave up" showed no significant changes in primary students' knowledge of economics and entrepreneurial content. Finally, those students at the primary grade levels had significantly higher scores (99\% significance level) for the mean of questions 11 through 20.

\begin{tabular}{|c|c|c|c|c|}
\hline Content Questions & & Primary & Fourth & Fifth \\
\hline 11 & $\begin{array}{c}\text { Pretest } \\
\text { Posttest } \\
\text { Sig. Level }\end{array}$ & $\begin{array}{l}0.15 \\
1.00 \\
\text { 仑ิ仑 }\end{array}$ & $\begin{array}{l}0.44 \\
0.86 \\
\text { 仓ิ仑 }\end{array}$ & $\begin{array}{l}0.33 \\
0.82 \\
\text { 仑ิ̂े }\end{array}$ \\
\hline 12 & $\begin{array}{c}\text { Pretest } \\
\text { Posttest } \\
\text { Sig. Level }\end{array}$ & $\begin{array}{l}0.27 \\
0.82 \\
\text { 仓ิ }\end{array}$ & $\begin{array}{l}0.36 \\
0.90 \\
\text { 仓ิ }\end{array}$ & $\begin{array}{l}0.41 \\
0.92 \\
\text { 仓ิ仑 }\end{array}$ \\
\hline 13 & $\begin{array}{c}\text { Pretest } \\
\text { Posttest } \\
\text { Sig. Level }\end{array}$ & $\begin{array}{l}0.12 \\
0.25 \\
\text { 仑ิ仑̂ }\end{array}$ & $\begin{array}{l}0.19 \\
0.32 \\
\text { 仑ิ仑̂ }\end{array}$ & $\begin{array}{l}0.29 \\
0.52 \\
\text { 仑ิ仑仑 }\end{array}$ \\
\hline 14 & $\begin{array}{c}\text { Pretest } \\
\text { Posttest } \\
\text { Sig. Level }\end{array}$ & $\begin{array}{l}0.19 \\
0.68 \\
\text { 仑ิ仑 }\end{array}$ & $\begin{array}{l}0.11 \\
0.59 \\
\text { 仑ิ仑 }\end{array}$ & $\begin{array}{l}0.38 \\
0.83 \\
\text { 仑ิ仑 }\end{array}$ \\
\hline 15 & $\begin{array}{c}\text { Pretest } \\
\text { Posttest } \\
\text { Sig. Level }\end{array}$ & $\begin{array}{l}0.35 \\
0.86 \\
\text { 仓ิ }\end{array}$ & $\begin{array}{l}0.53 \\
0.78 \\
\text { 仓ิ }\end{array}$ & $\begin{array}{l}0.39 \\
0.92 \\
\text { 仓ิ仑 }\end{array}$ \\
\hline 16 & $\begin{array}{c}\text { Pretest } \\
\text { Posttest } \\
\text { Sig. Level }\end{array}$ & $\begin{array}{l}0.58 \\
0.57\end{array}$ & $\begin{array}{l}0.36 \\
0.75 \\
\text { 仑ิ }\end{array}$ & $\begin{array}{l}0.43 \\
0.68 \\
\text { 仑̂ิ }\end{array}$ \\
\hline 17 & $\begin{array}{c}\text { Pretest } \\
\text { Posttest } \\
\text { Sig. Level }\end{array}$ & $\begin{array}{l}0.42 \\
0.61 \\
\text { 仓ิ仑 }\end{array}$ & $\begin{array}{l}0.35 \\
0.68 \\
\text { 仓ิ仑 }\end{array}$ & $\begin{array}{l}0.46 \\
0.67 \\
\text { 仑ิ仑ิ }\end{array}$ \\
\hline 18 & $\begin{array}{c}\text { Pretest } \\
\text { Posttest } \\
\text { Sig. Level }\end{array}$ & $\begin{array}{l}0.54 \\
0.93 \\
\text { 仓ิ }\end{array}$ & $\begin{array}{l}0.52 \\
0.90 \\
\text { 仓ิ }\end{array}$ & $\begin{array}{l}0.56 \\
0.81 \\
\text { 仓ิ̂ }\end{array}$ \\
\hline 19 & $\begin{array}{c}\text { Pretest } \\
\text { Posttest } \\
\text { Sig. Level }\end{array}$ & $\begin{array}{l}0.38 \\
0.50\end{array}$ & $\begin{array}{l}0.57 \\
0.82 \\
\text { 仓ิ仑 }\end{array}$ & $\begin{array}{l}0.50 \\
0.78 \\
\text { 仓ิ仑 }\end{array}$ \\
\hline
\end{tabular}




\begin{tabular}{|c|c|c|c|c|}
\hline Content Questions & & Primary & Fourth & Fifth \\
\hline 20 & $\begin{array}{c}\text { Pretest } \\
\text { Posttest } \\
\text { Sig. Level }\end{array}$ & $\begin{array}{l}0.35 \\
0.61 \\
\text { 仓ิ }\end{array}$ & $\begin{array}{l}0.38 \\
0.66 \\
\text { 仓ิ }\end{array}$ & $\begin{array}{l}0.41 \\
0.78 \\
\text { 仓ิ }\end{array}$ \\
\hline Mean 11-20 & $\begin{array}{c}\text { Pretest } \\
\text { Posttest } \\
\text { Sig. Level }\end{array}$ & $\begin{array}{c}3.2 \\
26.79 \\
\text { 仓ि }\end{array}$ & $\begin{array}{l}3.73 \\
7.19 \\
\text { 仓ि }\end{array}$ & $\begin{array}{l}3.65 \\
7.46 \\
\text { 仓ि }\end{array}$ \\
\hline
\end{tabular}

Students at the fourth and fifth elementary grade levels scored significantly higher on all 10 questions related to knowledge of economic and entrepreneurial concepts. All scores were statistically significant at the 99\% significance level for students in this group. In addition, those students at the primary, fourth, and fifth grade levels had significantly higher scores (99\% significance level) for the mean of questions 11 through 20.

\section{ANOVA}

The results of the one-way analysis of variance, presented in Table 8 show that there was not a significant difference between the three groups (primary, fourth grade, and fifth grade) for the pretest scores. Specifically, the F-test statistic for the difference in pretest means was 1.26 with a P-value of 0.29 , indicating that the null hypothesis that there was no significant difference between the elementary group means could not be rejected. This indicates that grade level was not a significant factor at the elementary curriculum level.

In addition, there was not a significant difference between the three groups on the posttest scores. The F-test statistic for the posttest means was 0.98 and a P-value of 0.40 , indicating that the null hypothesis that there was no significant difference among elementary grade level groups could not be rejected. Consequently, the results of the ANOVA in Table 8 indicate that the elementary students' grade level is not a significant variable for the pretest or posttest scores.

\begin{tabular}{|c|c|c|c|}
\hline Grade & $\begin{array}{l}\text { Pretest, Mean Score, } \\
\text { Questions 11-20 }\end{array}$ & $\begin{array}{l}\text { Posttest, Mean Score, } \\
\text { Questions 11-20 }\end{array}$ & $\begin{array}{c}\text { t-test Significance Level, Mean Score, } \\
\text { Questions 11-20 }\end{array}$ \\
\hline Primary & 3.22 & 6.79 & 仓仓 \\
\hline Fourth & 3.73 & 7.19 & 仓仓 \\
\hline Fifth & 3.65 & 7.46 & 仓ิ \\
\hline $\begin{array}{l}\text { F-Value } \\
\text { P-Value }\end{array}$ & $\begin{array}{l}1.26 \\
0.29\end{array}$ & $\begin{array}{l}0.98 \\
0.40\end{array}$ & \\
\hline
\end{tabular}




\section{SUMMARY}

The purpose of this study was to determine if there was a significant change in elementary student dispositions toward, and knowledge of, entrepreneurs and economic content as a result of their participation in the Kentucky Council on Economic Education's Entrepreneurs in Kentucky program. Specifically, the study examined the difference in the mean pretest and posttest scores for both dispositions toward, and knowledge of, entrepreneurial and economic concepts using the evaluation instrument developed and administered by the Kentucky Council on Economic Education's Entrepreneurs in Kentucky initiative.

At the elementary curriculum level, two research questions were posed for statistical analysis. These research questions treat the mean student scores for each of the seven bi-polar adjective dispositional questions, as well as the scores for the 10 multiple-choice knowledge/content questions on the student assessment instrument, as dependent variables. The independent variables were the individual elementary students' prior exposure to economic and entrepreneurial concepts and the individual elementary students' grade levels. The data was analyzed using a t-test to determine the significance of the difference between the mean pretest and posttest scores, and a single factor ANOVA was applied first to the pretest, and then to the posttest, to determine the importance of the independent variables.

The results of the analyses show that there was a significant increase in elementary student knowledge of economic and entrepreneurial concepts as a result of their participation in the Entrepreneurs in Kentucky initiative. In addition, the results indicate that there was also a significant change in student attitudinal dispositions toward economics and entrepreneurship as a result of their participation. This supports earlier research by Nakkula (2004), Kourilsky (1995), and Sosin, Dick and Reiser (1997) that demonstrated the successful integration of economic and entrepreneurial content and development of positive attitudinal dispositions in elementary classrooms. The Kentucky Council on Economic Education's elementary Entrepreneurs in Kentucky results bode well for the program in terms of eliciting positive student attitudinal dispositions and promotion of economic and entrepreneurial understanding.

\section{REFERENCES}

Becker, W. (1997). Teaching economics to undergraduates. Journal of Economic Literature 35(3): 147-73.

Block, Z., \& S. A. Stumpf. (1992). Entrepreneurship education research: Experience and challenge. In D. I. Sexton \& J. D. Kasarda, (Eds.), The state of the art of entrepreneurship (pp. 17-45). Cambridge, MA: Ballinger Publishing.

Brickell, H. \& M. Scott. (1976). The effectiveness of economic education in senior high schools. New York: Policy Studies in Education.

Journal of Entrepreneurship Education, Volume 9, 2006 
Brockhaus, R.H., \& P. S. Horwitz. (1986). The psychology of the entrepreneur. In C. Kent, D. Sexton, \& K. Vesper (Eds.), Encyclopedia of entrepreneurship (pp. 39-57). Cambridge, MA: Ballinger Publishing.

Brush, C. (1992). Research on women business owners: Past trends, new perspective, and future directions. Entrepreneurship Theory and Practice, 16(4), 5-30.

Clayton, G. E. (2005). Economics: Principles and practices. Columbus, OH: Glencoe Publishing.

Cooper, A. C. (1983). Entrepreneurship: Starting a new business. Pamphlet. National Federation of Independent Business.

Drucker, P.F. (2006). Classic Drucker. Boston: Harvard Business School Publishing.

Ede, F.O., P. Bhagaban, \& S.E. Calcich. (1998). African American students' attitudes toward entrepreneurship education. Journal of Education for Business 73(5), 291-296.

Gartner, W. B., \& K. H. Vesper. (1993). Experiments in entrepreneurship education: Successes and failures. Journal of Business Venturing, 8 (Spring), 179-187.

Gorman, G., D. Hanlon, \& W. King. (1997). Some research perspectives on entrepreneurship education, enterprise education, and education for small business management: A ten-year literature review. International Small Business Journal, April/June. Macclesfield Cheshire: United Kingdom: Woodcock Publications, LTD.

Greenspan, A. (1999). The interaction of education and economic change. The Region 13 (1).

Hatten, T. S. \& S. K. Ruhland. (1995). Student attitude toward entrepreneurship as affected by participation in an SBI program. Journal of Education for Business, 70(4), 224-227.

Kent, C. (Ed.). (1990). Entrepreneurship education: Current developments, future directions. Westport, CT: Quorum Books.

Kogan, V. (2005). UC-system professors say entrepreneurship education's new frontier. The Guardian.

Koon, S. (1995). The relationship of implementation of an entrepreneurial development innovation to student outcomes. Unpublished doctoral dissertation, University of Missouri, Kansas City.

Kourilsky, Marilyn. (1995). Entrepreneurship education: Opportunity in search of curriculum. Business Education Forum.

Krueger, N. (1993). The impact of prior entrepreneurial exposure on perceptions of new venture feasibility and desirability. Entrepreneurship Theory and Practice Fall, 5-21.

Laney, J. (1990). Generative teaching and learning of cost-benefit analysis: An empirical investigation. Journal of Research and Development in Education 23(3): 136-44.

Journal of Entrepreneurship Education, Volume 9, 2006 
Louis Harris \& Associates, Inc. (1999). Results from the standards in economics survey. The National Council on Economic Education Economics America [On-line]. Available: http://www.nationalcouncil.org/poll/results.html.

Mangan, K. (2004). Entrepreneurs in every department. The Chronicle of Higher Education, May 28.

McGraw, T.K. (1991). Schumpeter ascending (re-emerging intellectual interest in entrepreneurship, innovation, and economic development). The American Scholar, 60, 371-392.

Morgan, J. (1991). Using Econ and Me to teach economics to children in primary grades. Social Studies (September/October): 195-97.

Nakkula, M. (2004). Inventing the future. National Foundation for Teaching Entrepreneurship. [On-line]. Available: http://www.nfte.com.

National Commission on Entrepreneurship. (2002). Fast facts. In Policy makers toolkit. (On-line). Available: http://www.ncoe.org.

National Commission on Entrepreneurship. (2006). Embracing innovation: Entrepreneurship and American economic growth. [On-line]. Available: http://www.ncoe.org.

Partnership for $21^{\text {st }}$ Century Skills. (2006). Learning for the $21^{\text {st }}$ century. [On-line]. Available: http://www.21stcenturyskills.org.

Samuelson, P. \& W. Nordhaus. (2001). Economics (1 $7^{\text {th }}$ Ed.) Boston: McGraw-Hill Irwin.

Siegfried, J., \& W. Walstad. (1990). Research on teaching college economics. In P. Saunders \& W. Walstad (Eds.) The principles of economic course: A handbook for instructors. New York: McGraw-Hill.

Sosin, K., J. Dick, \& M. L. Reiser. (1997). Determinants of achievement of economics concepts by elementary school students. The Journal of Economic Education 28: 100-121.

Stiggins, R. (1994). Student-centered classroom assessment. New York: Merrill.

Walstad, W. (1980). The impact of "Trade-offs" and teacher training on economic understanding and attitudes. The Journal of Economic Education 12(1): 41-48.

Walstad, W. \& J. Soper. (1989). What is high school economics? Factors contributing to student achievement and attitudes. The Journal of Economic Education 20(1): 23-38.

Zacharakis, A.L., W.D. Bygrave, \& D.A. Shepherd. (2000). Global entrepreneurship monitor: National entrepreneurship assessment, United States of America. Kansas City, MO: Kaufman Center for Entrepreneurial Leadership. 


\section{Appendix Entrepreneurs in Kentucky Elementary Student Assessment}

Directions: Use two or three sentences to complete each thought in the space provided below:

- I think that an entrepreneur is:

I think I would be a (good or bad) entrepreneur because I:

Directions: For each question below, pick the numerical response that best fits the question.

3. I would _ an entrepreneur.

LIKE TO BE 1 --- 2 --- 3 --- 4 --- 5 --- 6 --- 7 NEVER WANT TO BE

4. I think that it would be to study about entrepreneurs.

$$
\text { FUN } 1 \text {--- } 2 \text {--- } 3 \text {--- } 4 \text {--- } 5 \text {--- } 6 \text {--- } 7 \text { BORING }
$$

5. Being an entrepreneur would be

$$
\text { HARD WORK } 1 \text {--- } 2 \text {--- } 3 \text {--- } 4 \text {--- } 5 \text {--- } 6 \text {--- } 7 \text { EASY }
$$

6. I think that entrepreneurs are ___ for our state and community.

$$
\text { BAD } 1 \text {--- } 2 \text {--- } 3 \text {--- } 4 \text {--- } 5 \text {--- } 6 \text {--- } 7 \text { GOOD }
$$

7. Personally, I know entrepreneurs.

$$
\text { MANY } 1 \text {--- } 2 \text {--- } 3 \text {--- } 4 \text {--- } 5 \text {--- } 6 \text {--- } 7 \text { FEW }
$$

8. Entrepreneurs ought to be appreciated

$$
\text { LESS } 1 \text {--- } 2 \text {--- } 3 \text {--- } 4 \text {--- } 5 \text {--- } 6 \text {--- } 7 \text { MORE }
$$
in our community.

9. I would like to know __ about entrepreneurs.

$$
\text { MORE } 1 \text {--- } 2 \text {--- } 3 \text {--- } 4 \text {--- } 5 \text {--- } 6 \text {--- } 7 \text { LESS }
$$

10. I would an entrepreneur in my town. LIKE TO MEET AND TALK TO 1 --- 2 --- 3 --- 4 --- 5 --- 6 --- 7 LIKE TO AVOID

Directions: Circle the response that best answers the question or completes the sentence.

11. Entrepreneurs usually
a) work for large businesses.
b) work for small businesses.
c) own their own businesses.
d) make huge profits in the stock market.

12. The entrepreneur receives
a) salary
b) profits
c) wages
d) interest and dividends

Journal of Entrepreneurship Education, Volume 9, 2006 
13. Three productive resources are
a) money, natural resources, machinery
b) entrepreneurs, money, products
c) people, capital goods, natural resources
d) products, money, land

14. Tools, machinery, and equipment would be examples of
a) supply and demand.
b) natural resources.
c) opportunity costs.
d) capital resources.

15. An entrepreneur is
a) a person who goes into business to make a profit.
b) a type of business.
c) someone who works for high wages and salaries.
d) someone with one of the easiest jobs in our economy.

16. The entrepreneur typically works
a) in a comfortable, air conditioned environment.
b) short hours and has a great deal of spare time.
c) long hours, which often leaves little time for recreation and other activities.
d) outdoors in activities such as forestry and agriculture.

17. Entrepreneurs are found most often in
a) businesses like education and tourism.
b) businesses with large manufacturing plants.
c) businesses like ranching and mining.
d) all businesses, regardless of size or type of product produced.

18. Someone who combines productive resources in hopes of earning a profit is a(n)
a) capitalist.
c) economist.
b) entrepreneur.
d) industrialist.

19. You give up an hour of math to study about entrepreneurs. The opportunity cost of studying entrepreneurs is
a) the hour of math you gave up.
b) the dollar cost of the paper and materials used in the lessons.
c) zero because the school supplies everything for free.
d) the dollar value of all the books and materials you use.

20. An entrepreneur is motivated by the
a) desire to be a better citizen.
b) possibility of earning a profit.
c) desire to have a comfortable, well-paid job.
d) opportunity to take long vacations. 


\title{
EDUCATION AND TRAINING AS NON-PSYCHOLOGICAL CHARACTERISTICS THAT INFLUENCE UNIVERSITY STUDENTS' ENTREPRENEURIAL BEHAVIOUR
}

\author{
Juan Hernangomez Barahona, University of Valladolid \\ Natalia Martin Cruz, University of Valladolid \\ Ana Isabel Rodriguez Escudero, University of Valladolid
}

\begin{abstract}
It is well known that entrepreneurship plays a key role in boosting innovation and well-being in an economy, but researchers have shed little light on how universities can motivate this propensity. In this current paper, our aim is to examine which complementary education and work experience measures prior to graduation universities can encourage in order to foster entrepreneurship. For this purpose, we analyse a sample of 2012 Spanish university students in the final years of their degrees in the academic year 2003-2004. Using a binary logistic regression analysis, we obtain results that generally confirm our expectations. That is, complementary educational activities and work experience prior to graduation can help to explain the propensity to create business start-ups.
\end{abstract}

\section{THEORETICAL APPROACH AND RESEARCH OBJECTIVES}

In recent years, public institutions such as education centres and other European institutions have become aware of the importance of developing an efficient business structure, which is capable of discovering and exploiting opportunities in an increasingly dynamic, complex and uncertain environment (Ronstandt, 1985; Scott et al., 1998; Meyer, 2003; Snijders \& Vander Horst, 2002).

The European Union (EU) is developing an active strategy of promoting entrepreneurship. Thus, the current strategy is reflected in policies such as the Multi-annual programme for Enterprise and Entrepreneurship for 2001-2005, Euro Info Centres and Innovation Relay Centres.

The emphasis on young people is particularly noteworthy, although hardly surprising, since this group contains the largest proportion of entrepreneurs in the EU (CEEDR, Middlesex University, 2000). By analysing the characteristics of this group of entrepreneurs in detail, we find that a large proportion of these individuals have taken courses up to degree level at university. In Spain, a higher proportion of entrepreneurs are young university graduates than the European average: $40.5 \%$ compared to $35 \%$ (Reynolds et al., 2002). 
Given this positive outlook for entrepreneurship among young graduates, the responsible authorities should design useful educational policies (Henderson \& Robertson, 1999). It is also clearly advisable to further our understanding of the elements that promote entrepreneurial inclinations. Thus, before teaching people how to start entrepreneurial activities, they must be induced with the desire to do so. Little is known about this aspect (Henderson \& Robertson, 1999).

Following Shane's (2003) reasoning, the attributes or features of individuals that influence their ability to evaluate and subsequently exploit the opportunities that emerge can be classified into two groups: psychological and non-psychological factors. This research focuses on the nonpsychological features of individuals that favour the exploitation of business opportunities. Among the main non-psychological factors we are interested in the demographic characteristics considered by the upper-echelon literature, such as age and gender, and the sociological variables, specifically those regarding education and work experience.

We consider that age has an inverted U-shaped relationship with entrepreneurship. On the one hand, it includes the positive effect derived from the individual's maturity, but on the other hand, there is the negative effect of the opportunity cost and uncertainty. The opportunity cost increases with age insofar as this latter variable is positively associated with income. However, uncertainty increases because life expectancy declines (Reynolds et al., 1994; Bates, 1995). Consequently, age has a positive effect on entrepreneurship for younger individuals, but after a certain age the relationship between age and entrepreneurship becomes negative.

Another feature, which is no less important but rarely studied, is the gender variable. Studied in the context of modern society, which is characterised by equal opportunities for men and women, it is of interest to researchers on entrepreneurship (Hisnichet et al., 1996; Duchénant \& Orhan, 2000; Orhan and Scott, 2001).

Researchers have shown that women's motivation to engage in business activities is very varied and can originate from diverse factors, such as the influence of the environment and the necessity or desire for self-realisation (Orhan \& Scott, 2001). According to Peters (2004), the role women play in the economy is one of the most significant phenomena of the early 21 st century. In the US, the number of women running a company increased from 9 million in 1997 to around 10.6 million in 2004 (Center for Women's Business Research, National Numbers, 2004). In spite of these figures, it seems that nowadays men are still more prone to set up their own company and take on the risk involved in any new venture.

From the sociological perspective, another set of variables affecting the decision to set up a firm comprises the individual's education and previous work experience (Bates, 1990; Cressy, 1996). Education and experience in other business activities provide individuals with information (about the market, the workforce, etc.) and skills (in sales, planning, decision-making, etc.) that improve their ability to combine the resources, develop a strategy, organise business activities and, in short, exploit opportunities more successfully (Corman et al, 1988; Lee, 1999; Shane \& Khurana, 2001). 
Specifically, researchers have found that one of the main characteristics of individuals running small enterprises is a higher educational level (Smith, 1967; Robinson \& Sexton, 1994; Lorrain \& Dussault, 1998). In particular, among the determinant factors of entrepreneurship, university education has been found to be very influential. Henderson and Robertson (1999) observe that students who have participated in postgraduate education programmes are more likely to set up their own firm. Researchers have also found a positive relationship between education and the firm's growth aspirations (Davidson et al., 2003; Matos, 2003).

Education at all levels plays a key role in the development of an entrepreneurial society. However, it is necessary to develop education in the most fundamental dimensions associated with the definition of personality and the learning of leadership skills (Fillion, 2004). In this vein, universities play an important role in training entrepreneurs as individuals of multiple characteristics (Lazear, 2003; Pleitner, 2003; Fayolle et al, 2004). Entrepreneurs, unlike specialists, possess a more harmonious education in all the areas of knowledge required to successfully exploit opportunities and manage the attitudes and tasks of individuals (including the specialists) who will go on to help them successfully develop their new business (Lazear, 2003). Greater knowledge, together with a higher level of information and skills, provides the individual with a greater capacity to undertake entrepreneurial activities and to assume or demonstrate entrepreneurial attitudes.

New entrepreneurs, apart from their higher educational level, also stand out for their increased work experience (Lorrain \& Dussault, 1998; Smith, 1967). The individual's experience is one of the variables that researchers have most frequently found to be significant in distinguishing between successful and unsuccessful entrepreneurs (Cooper et al., 1994; Gimeno et al., 1997; Burke et al., 2000 and 2002; Capelleras et al., 2004; Fayolle et al, 2004). Moreover, if the first experience has something to do with starting a business activity during the individual's youth, this makes the individual more likely to start another entrepreneurial activity later on (Ikei, 1997; Dobrev \& Barnett, 1999; Wandosell \& Garcia, 2004). To this we should add that entrepreneurs with some managerial experience acquired previously tend to create firms that grow faster compared to inexperienced individuals (Henderson \& Robertson, 1999; Capelleras et al., 2004). Also, people with a more varied previous experience are more likely to start their own business (Littunen, 2002) because they have been able to develop networks of influence and contacts. In this respect, an important finding is that the majority of European entrepreneurs have related past positions as specialist workers or managers in other firms. Thus, all of them had considerable knowledge and some previous business experience (Reynolds et al., 2002).

The current research (see Figure 1) has the aim of studying the influence of the abovementioned variables (age, gender, education and work experience) as fundamental determinants of the propensity to set up firms by university students close to graduation. In other words, we apply the general approach of the literature on entrepreneurship to an analysis of entrepreneurial orientation among university students. 
Figure 1: Model of entrepreneurial orientation

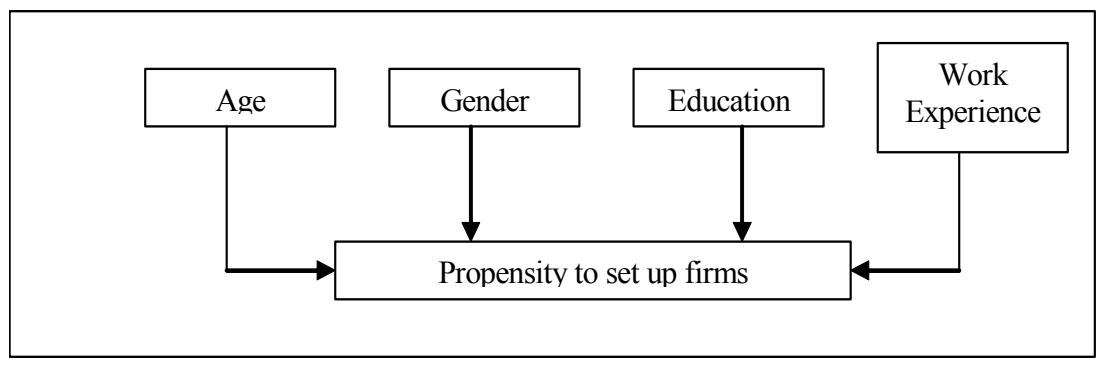

\section{METHODOLOGY}

The information that we used to test the empirical model proposed here was provided by the General Foundation (www.funge.uva.es) of the University of Valladolid (Spain). The Foundation has initiated a study called the "Professional Observatory of the University of Valladolid", whose aim is to conduct an exhaustive analysis of the current situation and problems of the academic degrees/studies and educational areas taught by the University of Valladolid with regards to their professional development, as well as to identify complementary education that would help graduates to adapt more closely to current labour-market needs.

In order to achieve this objective, various data collection tools have been developed that are directed at different students. One of these tools consists of a questionnaire directed at students from cycles 3-5 of the various degrees/studies (The Spanish university system offers students the possibility of choosing either 3-year or 5-year studies. Students successfully completing a 3-year degree ("first cycle") are awarded diplomas. These can then optionally continue for two more years ("second cycle") to complete a 5-year degree, whereupon they graduate). This is the source of information used in the current study. 2012 completed questionnaires were collected for the year 2004. The sample consists of $59.6 \%$ engineering students, $25.7 \%$ social sciences students and $14.6 \%$ humanities students.

The means of the age and gender variables show that more than half of the students surveyed are women, and that their average age is around 23 years. The group of education variables includes the acquisition of knowledge complementary to the university studies themselves, such as the level of foreign language ability, the number of stays abroad, the level of computer skills, and receiving other types of complementary non-university education (for instance, courses for developing job search skills, courses for developing teaching skills, sports training, musical training, among others). To evaluate the students' previous work experience, we considered firms' internships, voluntary/social work, work with a contractual work (in a position either related or unrelated to the student's speciality), work without a non-contractual work, and previous experience as a freelancer. The dependent variable of the study is a dichotomous variable measuring the students' orientation 
to create their own firm after graduating. $63 \%$ of students in the sample do not want to become entrepreneurs and $37 \%$ desire to set up a new company.

Table 1 provides more information about the variable measurements and their average values for the sample individuals. Before we tested the hypotheses, we examined the correlation matrix (see Table 2). The signs of the bivariate correlation appear to be consistent with the hypothesized relationships.

\begin{tabular}{|l|c|c|}
\hline \multicolumn{3}{|c|}{ Table 1: Variable measurement and descriptive analysis } \\
\hline \multicolumn{1}{|c|}{ Variable } & Measure & Mean (std. dev.) \\
\hline Propensity to set up firms & $0 / 1(\mathrm{No} / \mathrm{Yes})$ & $0.37(0.48)$ \\
\hline Age & Years & $23.41(2.93)$ \\
\hline Gender & $0 / 1$ (Male/Female) & $0.56(0.49)$ \\
\hline EDUCATION & & \\
\hline Foreign language skills & Numeric & $2.74(1.72)$ \\
\hline Number of stays abroad & Numeric & $1.15(3.57)$ \\
\hline Computer skills level & Numeric & $1.24(0.48)$ \\
\hline Complementary non-university education & Numeric & $1.12(1.04)$ \\
\hline EXPERIENCE & & \\
\hline Internship experience & $0 / 1(\mathrm{No} / \mathrm{Yes})$ & $0.21(0.41)$ \\
\hline Experience as a volunteer & $0 / 1(\mathrm{No} / \mathrm{Yes})$ & $0.14(0.35)$ \\
\hline Contractual experience (job not related to studies) & $0 / 1(\mathrm{No} / \mathrm{Yes})$ & $0.30(0.46)$ \\
\hline Contractual experience (job related to studies) & $0 / 1(\mathrm{No} / \mathrm{Yes})$ & $0.10(0.30)$ \\
\hline Non-contractual experience & $0 / 1(\mathrm{No} / \mathrm{Yes})$ & $0.32(0.47)$ \\
\hline Experience as an entrepreneur/freelancer & $0 / 1(\mathrm{No} / \mathrm{Yes})$ & $0.025(0.16)$ \\
\hline
\end{tabular}

The analytical methodology used was binary logistic regression, in which the dependent variable was the students' propensity to set up their own firm. Logistic regression analysis is well suited when the dependent variable is non-metric and consists of just two groups. Compared to discriminant analysis, choosing logistic regression is justified by the fact that the multivariate normality assumptions do not need to be met. Logistic regression is much more robust when these assumptions are not met. But even if they are met, many researchers prefer this methodology to discriminant analysis, because the interpretation of the results is similar to that of regression analysis results.

Logistic regression also tests the hypothesis that a coefficient is different from zero as is done in multiple regression, where the $t$ value is used to assess the significance of each coefficient. Although logistic regression uses a different statistic, the Wald statistic, it also provides the 
statistical significance for each estimated coefficient so that hypothesis testing can occur just as it did in multiple regression.

\begin{tabular}{|c|c|c|c|c|c|c|c|c|c|c|c|c|}
\hline & -1 & -2 & (3) & (4) & (5) & (6) & (7) & (8) & (9) & (10) & (11) & (12) \\
\hline \multicolumn{13}{|l|}{$\begin{array}{l}\text { (1) Propensity } \\
\text { to } \\
\text { set up firms }\end{array}$} \\
\hline (2) Age & $.06^{* * *}$ & & & & & & & & & & & \\
\hline (3) Gender & $-.10 * * *$ & $-.07 * * *$ & & & & & & & & & & \\
\hline $\begin{array}{l}\text { (4) Foreign } \\
\text { language skills }\end{array}$ & $.06^{* *}$ & $-.04 *$ & $.05^{* *}$ & & & & & & & & & \\
\hline $\begin{array}{l}\text { (5) Number of } \\
\text { stays abroad }\end{array}$ & $.08^{* * *}$ & $.05 * *$ & 0 & $.28^{* * *}$ & & & & & & & & \\
\hline $\begin{array}{l}\text { (6) Computer } \\
\text { skills level }\end{array}$ & $.11 * * *$ & 0.03 & $-.29 * * *$ & $.09 * * *$ & -.01 & & & & & & & \\
\hline $\begin{array}{l}\text { (7) Comple- } \\
\text { mentary non- } \\
\text { university } \\
\text { education }\end{array}$ & $.10^{* * *}$ & $.16^{* * *}$ & $.07 * *$ & $.23 * * *$ & $.11^{* * *}$ & $.09 * * *$ & & & & & & \\
\hline $\begin{array}{l}\text { (8) Internship } \\
\text { experience }\end{array}$ & $.07 * * *$ & $.11^{* * *}$ & $.04 *$ & $.07 * * *$ & .02 & -.03 & $.17 * * *$ & & & & & \\
\hline $\begin{array}{l}\text { (9) Experience } \\
\text { as a volunteer }\end{array}$ & $.07 * * *$ & -.03 & $.11^{* * *}$ & $.05^{* *}$ & $.04 *$ & -.02 & $.17 * * *$ & -.01 & & & & \\
\hline $\begin{array}{l}\text { (10) Contract- } \\
\text { ual experience } \\
\text { (job not related } \\
\text { to studies) }\end{array}$ & $.07 * * *$ & $.14 * * *$ & $-.09 * * *$ & $.04 *$ & $.06 * * *$ & -.03 & $.13 * * *$ & $.07 * * *$ & $.08 * * *$ & & & \\
\hline $\begin{array}{l}\text { (11) Contract- } \\
\text { ual experience } \\
\text { (job related to } \\
\text { studies) }\end{array}$ & $.07 * * *$ & $.19 * * *$ & .00 & $.05^{*}$ & $.10^{* * *}$ & -.04 & $.16^{* * *}$ & $.12 * * *$ & $.09 * * *$ & $.09 * * *$ & & \\
\hline $\begin{array}{l}\text { (12) Non- } \\
\text { contractual } \\
\text { experience }\end{array}$ & $.13^{* * *}$ & -.00 & -.00 & $.04 *$ & $.04 *$ & -.00 & $.11^{* * * *}$ & .00 & $.10 * * *$ & $.09 * * *$ & .02 & \\
\hline $\begin{array}{l}\text { (13) Exper- } \\
\text { ience as an } \\
\text { entre-preneur/ } \\
\text { freelancer }\end{array}$ & $.09 * * *$ & $.11^{* * * *}$ & $-.08 * * *$ & 0.03 & 0 & $.05 * * *$ & 0.03 & 0 & 0 & $.06^{* *}$ & 0 & 0 \\
\hline
\end{tabular}

Specifically, we used a hierarchical logistic regression. This methodology allows us to sequentially introduce different blocks of variables and to check their respective explanatory capacities. Firstly, we included the block corresponding to the main effects of all the independent variables (Model 1). Finally, we add the variable age squared to these variables, to test for the existence of an inverted U-shaped relationship (Model 2). The relevance of the inverted U-shaped effect cannot be rejected if the corresponding Wald-statistic is significant. 
We used three global goodness-of-fit indices. Firstly, we use the log-likelihood (-2LL), for which low values indicate a better model fit. This index is similar to the residual or error sums of square values for multiple regression. Secondly, we use the Hosmer and Lemeshow test, which measures the correspondence between the observed and expected results of the dependent variable. A non-significant value indicates a good fit. Finally, we apply the Nagelkerke $\mathrm{R}^{2}$, which is interpreted similarly to the $\mathrm{R}^{2}$ of any multiple regression model. In logistic regression, there is no true $\mathrm{R}^{2}$ value as there is in OLS regression. However, because deviance can be thought of as a measure of how poorly the model fits (i.e., lack of fit between observed and predicted values), an analogy can be made to the sum of squares residual in ordinary least squares. The proportion of unaccounted for variance that is reduced by adding variables to the model is the same as the proportion of accounted for variance, or $\mathrm{R}^{2}$. An index that reflects this basic idea has been developed by Nagelkerke.

\section{RESULTS}

Table 3 presents the results from the regression. The logistic regression conducted on the entire sample has suitable adjustment indexes. An important number of variables are significant in explaining the students' entrepreneurial orientation.

With regards to gender, our expectations are met $(-0.36, \mathrm{p}<0.01)$. Women are indeed less likely to start businesses than men. Age, however, does not have an effect on entrepreneurship, neither when we consider the positive and linear effect, nor when we consider the quadratic effect. When the 'age' variable is included the $-2 \mathrm{LL}$ index barely changes and the Nagelkerke $\mathrm{R}^{2}$ does not change. This may be because the sample individuals show little variability in this variable. $98 \%$ of the sample are under 30 years old.

With regards to complementary education, computer skills $(0.39, \mathrm{p}<0.01)$ and education $(0.10, \mathrm{p}<0.05)$ in other areas are both important. We do not find foreign language ability to be relevant, but stays abroad are $(0.30, \mathrm{p}<0.05)$. However, both variables - foreign language ability and number of stays abroad-are highly correlated $(0.28, \mathrm{p}<0.01)$. This result can indicate that the first condition is necessary but not enough to motivate entrepreneurial behaviour. Foreign language ability during stays abroad has a much more positive effect on entrepreneurship than when it is put into practice without travelling from home.

Previous work experience also has an important role in explaining the propensity to set up firms. Specifically, the uncertainty that is related to non-contractual work $(0.50, \mathrm{p}<0.01)$ seems to stimulate students to create their own professional environment. We might interpret internships $(0.28, p<0.01)$ and volunteering $(\mathrm{p}<0.37, \mathrm{p}<0.01)$ that way. However, contractual work experience is not associated with the desire to create firms. This may be because once students have experienced the absence of risk in contractual work they will adapt to this or look for a similarly comfortable situation, rather than contemplate starting their own firm. 
Finally, among all these results perhaps the most noteworthy is the strong propensity to create firms among individuals that have already had experience as entrepreneurs/freelancers $(0.82$, $\mathrm{p}<0.01)$. The extent of the effect is much larger than that observed for the rest of the variables.

\begin{tabular}{|c|c|c|c|c|}
\hline \multicolumn{3}{|c|}{ Variable } & Beta & Wald \\
\hline \multicolumn{3}{|l|}{ Constant } & $-1.83 * * *$ & 16.8 \\
\hline \multicolumn{3}{|l|}{ Age } & 0.02 & 1.12 \\
\hline \multicolumn{3}{|l|}{ Gender } & $-0.36 * * *$ & 10.92 \\
\hline \multicolumn{5}{|c|}{ EDUCATION } \\
\hline \multicolumn{3}{|c|}{ Foreign language skill } & 0.02 & 0.39 \\
\hline \multicolumn{3}{|c|}{ Number of stays abroad } & $0.30 * *$ & 4.62 \\
\hline \multicolumn{3}{|c|}{ Computer skills level } & $0.39 * * *$ & 12.29 \\
\hline \multicolumn{3}{|c|}{ Complementary non-university education } & $0.10^{* *}$ & 4.11 \\
\hline \multicolumn{5}{|c|}{ EXPERIENCE } \\
\hline \multicolumn{3}{|c|}{ Internship experience } & $0.28 * *$ & 5.34 \\
\hline \multicolumn{3}{|c|}{ Experience as a volunteer } & $0.37 * *$ & 6.63 \\
\hline \multicolumn{3}{|c|}{ Contractual experience (job not related to studies) } & 0.12 & 1.09 \\
\hline \multicolumn{3}{|c|}{ Contractual experience (job related to studies) } & 0.17 & 1.11 \\
\hline \multicolumn{3}{|c|}{ Non-contractual experience } & $0.50 * * *$ & 22.92 \\
\hline \multicolumn{3}{|c|}{ Experience as an entrepreneur/freelancer } & $0.82 * * *$ & 7.37 \\
\hline MODEL 1 & $\begin{array}{l}-2 \mathrm{LL} \text { value } \\
\text { Hosmer and Lemeshow } \\
\text { Nagelkerke } \mathrm{R}^{2} \\
\text { No. observations }\end{array}$ & $\begin{array}{c}342 \\
4.38(0.82) \\
0.08 \\
2012\end{array}$ & & \\
\hline \multicolumn{3}{|l|}{$\mathrm{Age}^{2}$} & $\begin{array}{l}-0.002 \\
\end{array}$ & 1.43 \\
\hline MODEL 2 & $\begin{array}{l}\text {-2LL value } \\
\text { Hosmer and Lemeshow } \\
\text { Nagelkerke } \mathrm{R}^{2} \\
\text { No. observations }\end{array}$ & $\begin{array}{c}2341 \\
6.54(0.59) \\
0.08 \\
2012\end{array}$ & & \\
\hline
\end{tabular}




\section{DISCUSSION AND CONCLUSIONS}

In general, the factors recognised in the entrepreneurship literature as determinants of a stronger entrepreneurial orientation are highly significant in the present study. In other words, university students' propensity to create firms is explained by demographic, educational and work experience variables.

Women continue to show lower entrepreneurial behaviour compared to men, however nowadays the situation has improved. This conclusion is consistent with the results of previous international literature. In particular, in Spain this reality can be explained by our historical and cultural heritage. Our results have to be assessed by universities while discussing new and specific policies to promote entrepreneurial behaviour among members of this institution.

Education is one of the strongest engines of entrepreneurial orientation, especially, if it is associated with the opening of minds brought about by travelling and confronting the individual's knowledge with that of other countries. Initiatives such as exchange programmes are fundamental for producing enterprising students. At the same time, complementary education that is not part of their formal degree gives students the possibility of interrelating their specialised knowledge with that of other areas, which will be the seed of entrepreneurial ideas. Thus, these extra areas should complement formal education in order to foster entrepreneurship.

This is particularly the case with computer ability, since fast technological development means that this skill is essential in almost all business projects. Our findings show that it catalyses students' entrepreneurial initiatives.

On the other hand, work experience in firms helps to turn students into entrepreneurs. This is particularly true when the job is not too formal. Thus, rather than the flexibility of the labour market achieved through temporary work agencies, what helps the most is to design internships during which students face varied experiences in an organisation, in either a for-profit or non-profit context. Thus, universities should encourage university-firm collaboration, or the creation of groups of entrepreneurs that support and advise students about how to exploit their ideas and set up their

own firms. We can suggest the following recommendations for university authorities wishing to foster entrepreneurship among their students:

1. Since students with computer skills are more likely to start firms than others, this type of education should be essential in all degrees. University teaching should incorporate this technology as part of normal teaching routines, so that all students are assumed to have such knowledge when they graduate, just as correct use of language and the ability to express oneself well are assumed nowadays. 
2. Students who have previously created their own business or participated in a start-up are more likely to repeat the experience. This result helps us to claim that Universities should promote courses in which students are faced with the creation of a new venture. This can be done both by trying to create real new businesses or by participating in simulation exercises.

3. Another possible way of generating entrepreneurs would be to make it easier and quicker for students to set up their own firms in practice, by establishing collaborations between the university and the public institutions responsible for fostering entrepreneurship. These collaborative agreements can lead to the simplification of the bureaucratic procedures prior to the start of business activities.

4. Although the situation has improved, women still show fewer propensities to create firms than men. This situation should be evaluated carefully by universities, which should then establish policies for promoting entrepreneurship specifically for potential female entrepreneurs.

\section{LIMITATIONS AND FUTURE RESEARCH}

This paper has some limitations. However, the identification and correction of these limitations could give rise to new streams of future research. Firstly, the low value for the Nagelkerke $\mathrm{R}^{2}$ indicates a limited explanation of the variance by variables included in this research. We think that other individual-related variables, like the psychological profile of students -riskaversion, autonomy or self-confidence- could improve the explanation of entrepreneurial behaviour. Risk-aversion is negatively related to the exploitation of new business opportunities. Taking risks is an essential part of entrepreneurial activity (Van Praag \& Cramer, 2001; Stewart \& Roth, 2001). Students' independent behaviour could have a positive relationship with the need to create their own business. We claim that independent individuals have difficulties in accepting rigid organisations and procedures and are averse to hierarchical structures. Thus, they will be willing to make their own decisions and to initiate their own ventures, independently of other peoples' beliefs (Koh, 1996; Douglas, 1999). Finally, self-confidence is positively related to entrepreneurial behaviour. This psychological feature means that the individual will trust in his own skills and abilities to control the environment in which his business will grow (Davidsson, 2001; Matos, 2003).

These psychological variables could be used in an enlarged model to explain the entrepreneurial propensity to create new ventures. Other than that, it could be interesting to evaluate the potential interactions and synergies among these individual-related characteristics and the non- 
psychological ones. By identifying these effects, we could focus the institutional efforts more efficiently to increase the number of new businesses created by university graduates.

Another limitation of our research is related to the cross-sectional data. We cannot observe with our data if students with a high entrepreneurial propensity will indeed become new entrepreneurs. Thus, we suggest longitudinal research in which we follow the students once they finish university. This information will allow us to find out if students with an entrepreneurial inclination finally became entrepreneurs and then, we could identify those individual-related variables that are more persistent and determinant of entrepreneurial propensity.

\section{REFERENCES}

Bates, T. (1990). Self-employment trends among Mexican Americans. Economic Studies, CES, 90-9.

Bates, T. (1995). Self-employment entry across industry groups. Journal of Business Venturing, 10(2), 143-56.

Burke, A.E., F.R. Fitzroy \& M.A. Nolan (2000). When less is more: distinguishing between entrepreneurial choice and performance. Oxford Bulletin of Economics and Statistics, 62(5), 565-587.

Burke, A.E., F.R. Fitzroy \& M.A. Nolan (2002). Self-employment wealth and job creation: the roles of gender nonpecuniary motivation and entrepreneurial ability. Small Business Economics, 19, 255-270.

Capelleras, J.L., E. Genescá \& J.M. Veciana (2004). Determinants of Start-up and subsequent growth: A multivariate analysis. Proceedings of the XIV Congreso ACEDE, Murcia.

Casson, M., (2003). The Entrepreneurship: An Economic Theory (2 ${ }^{\text {nd }}$ Edition). Ed. Edward Elgar, USA.

CEEDR (2000). Young Entrepreneurs, Women Entrepreneurs, Co-Entrepreneurs and Ethnic Minority Entrepreneurs in the European Union and Central and Eastern Europe. Final report to the European Commission, DG Enterprise. Middlesex University Business School, UK.

Center for Women's Business Research (2004). National Numbers.

Cooper, A. C., J. Gimeno \& C. Y. Woo (1994). Initial human and financial capital as predictors of new venture performance. Journal of Business Venturing, 9, 371-395.

Corman, J., B. Perles \& P. Yancini (1988). Motivational factors influencing high-technology entrepreneurship. Journal of Small Business Management, 10(1), 7-23.

Cressy, R. (1996). Are Business Startups Debt-Rationed?. The Economic Journal, 106, September, 1253-1270.

Davidsson P. \& J. Wiklund (2001). Levels of analysis in entrepreneurship research: Current research practices and suggestions for the future. Entrepreneurship Theory and Practice, 25(Summer), 81-99.

Journal of Entrepreneurship Education, Volume 9, 2006 
Davidsson, P. \& B. Honing (2003). The role of social human capital among nascent entrepreneurs. Journal of Business Venturing, 18, 301-331.

Dobrev, S. \& W. Barnett (1999). Organizational roles and transitions to entrepreneurship. Research paper $n$. 1587, Graduate School of Business, Stanford University.

Douglas, E. (1999). Entrepreneurship as a career choice: Attitudes, entrepreneurial intentions, and utility maximization. In P. Reynolds, W. Bygrave, S. Manigart, C. Mason, G. Meyer, H. Sapienza y K. Shaver (Editors), Frontiers of Entrepreneurship Research (PP. 152-66), Babson Park, US: Babson College.

Duchénant, B. \& M. Orhan (2000). Les femmes entrepreneurs en France : Percée des femmes dans un monde construit au masculin, Seli Arslan, Paris.

Fayolle, A., A. Vernier \& B. Djiane (2004). Les jeunes diplômes de l'enseignement supérieur sont-ils des créateurs d'entreprise comme les autres?. Gestion 2000, 22(5), 39-56.

Fillion, L. J, (2004). Um Roteiro para Desenvolver o Empreendedorismo. Congresso Internacional de Empreendedorismo, Recife, Brasil.

Henderson, R. \& M. Robertson (1999). Who wants to be an entrepreneur? Young adult attitudes to entrepreneurship as a career. Education \& Training, 41(4/5),236-245.

Hisrich, R.D., C. Brush, D. Good \& G. De Souza (1996). Some preliminary findings on performance in entrepreneurial ventures: Does gender matter?. Frontiers of Entrepreneurship Research, Babson College, Wellesley, MA.

IKEI (1997). Dinámica empresarial en Navarra: 1990-1995, Gobierno de Navarra, España.

Koh, H. C. (1996). Testing hypotheses of entrepreneur Characteristics. Journal of Managerial Psychology, 11, $12-25$.

Lazear, E. P. (2003). Entrepreneurship. Discussion Paper Series, IZA DP No 760.

Lee, A. (1999). Empirical studies of self-employment. Journal of Economic Surveys, 13(4), 381-416.

Littunen, H. (2002). "Entrepreneurship and the characteristics of the entrepreneurial personality". International Journal of Entrepreneurial Behaviour \& Research, 6(6), 295-302.

Lorrain, J. \& L. Dussault (1988). Les entrepreneurs artisans et opportunistes: une comparaison de leurs comportements de gestion. Révue Internationale P.M.E., 1(2), 157-169.

Matos, J.J., (2003). Estudo do Crescimento e Desempenho das Pequenas Empresas: A Influencia da Orientação Estratégica Empreendedora. PHD Dissertation, University of Beira Interior, Portugal.

Meyer, M. (2003). Academia entrepreneurs or entrepreneurial academics? Research-based ventures and public support mechanisms. $R$ \& D Management, 33(2), 107-115.

Journal of Entrepreneurship Education, Volume 9, 2006 
Minniti, M. \& W. Bygrave (1999). The microfoundations of entrepreneurship. Entrepreneurship Theory and Practice, 23(4), 41-52.

Orhan, M. \& D. Scott (2001). Why women enter into entrepreneurship: An explanatory model. Women in Management Review, 16(5/6), 232-243.

Peters, T. (2004). As mulheres e o novo mercado. HSM Management, 3, 6-14.

Pleitner, H. J. (2003). “Entrepreneurship-Fashion or driving force?”. In Creación de Empresas - Entrepreneurship (PP. 45-48), Servei de Publicacions, University Autònoma de Barcelona.

Reynolds, P., D. Storey \& P. Westhead (1994). Cross-national variations in new firm formation rates. Regional Studies, $28,443-456$.

Reynolds, P., W. Bygrave, E. Autio, L. Cox \& M. Hay (2002). Global entrepreneurship monitor. 2002 Executive report, Babson Collage.

Robinson, P. \& E. Sexton (1994). The effect of education and experience on self-employment success. Journal of Business Venturing, 9(2), 141-156.

Ronstadt, R. (1985). The educated entrepreneurs: A new era of entrepreneurial education is beginning. American Journal of Small Business, 10(1), 7-23.

Scott, M, P. Rosa \& H. Klandt (1998). Introduction: Educating entrepreneurs for wealth creation, Aldershot: Ashgate.

Shane, S., (2003). A general theory of entrepreneurship-The individual-opportunity nexus, Edward Elgar Editores.

Shane, S. \& R. Khurana (2001). Career experiences and firm foundings. Paper presented at the Academy of Management Meetings.

Shane, S. \& S. Venkataraman (2000). The promise of entrepreneurship as a field of research. Academy of Management Review, 26(1), 13-17.

Smith, N.R. (1967). The entrepreneur and his firm. E. Lansing, MI: Michigan State University Bureau of Business and Economic Research.

Snijders, J. \& R. Van der Horst (2002). Las PYMEs europeas en estudio. Principales resultados del observatorio de las PYMEs europeas 2000, Observatorio de las PYMEs europeas 2002, Belgium.

Stewart, W. \& P. Roth (2001). Risk taking propensity differences between entrepreneurs and managers: A meta-analytic review. Journal of Applied Psychology, 86(1), 145-53.

Van Praag, C. \& J. Cramer (2001), "The roots of entrepreneurship an labour demand: Individual ability and low risk aversion. Economica, 68(269), 45-62. 
Venkataraman, S. (1997). The distinctive domain of entrepreneurship research: An editor's perspective. In J. Katz \& R. Brockhaus (editors), Advances in Entrepreneurship, Firm Emergence, and Growth, 3, Greenwich, CT, US: JAI Press, 119-38.

Wandosell, G. \& A. Garcia (2004). Motivaciones y obstáculos en la creación de empresas, efectos de la experiencia empresarial. Boletín Económico del ICE, 2819, 11-17. 


\title{
THE EFFECTS OF PERSONALITY AND EXPERIENCE ON RESOURCE ACQUISITION PERFORMANCE: AN EXPERIMENTAL STUDY
}

\author{
Steven E. Phelan, University of Nevada Las Vegas \\ G. Stoney Alder, University of Nevada Las Vegas
}

\begin{abstract}
Nexus theory (Venkataraman, 1997; Shane \& Venkataraman, 2000; Shane, 2003) predicts that entrepreneurial behavior will result from an interaction of the quality of the opportunity and the entrepreneur's psychological characteristics and experience. In this paper, we utilized a laboratory bargaining experiment to partially test nexus theory, focusing exclusively on the resource acquisition phase of the entrepreneurial process. As predicted, we found that several relevant personality traits improved profit performance on a resource acquisition game but only for subjects with previous task experience. Specifically, risk-taking propensity, locus of control, creativity, and social astuteness interacted with task experience to determine participants ' profits. Implications for entrepreneurial research and practice are discussed.
\end{abstract}

\section{INTRODUCTION}

Until recently, the prevailing wisdom in entrepreneurship has been that psychological characteristics do not reliably distinguish entrepreneurs from non-entrepreneurs (Brockhaus \& Horwitz, 1986; Gartner, 1988). In fact, even the most promising traits (such as need for achievement or locus of control) have not tended to distinguish entrepreneurs from managers or other successful people (Low \& MacMillan, 1988; Busenitz \& Barney, 1997). Recently, however, there has been a renewed interest in research on entrepreneurial traits, driven by greater methodological sophistication and a more nuanced examination of the entrepreneur and the entrepreneurial process (Stewart, Watson, Carland, \& Carland, 1999; Stewart \& Roth, 2001; Ciavarella, Buchholtz, Riordan, Gatewood, \& Stokes, 2004; Collins, Hanges, \& Locke, 2004).

One response to this trend has been the development of "individual-opportunity nexus" theory (referred to hereafter simply as nexus theory) (Venkataraman, 1997; Shane \& Venkataraman, 2000; Eckhardt \& Shane, 2003; Shane, 2003). In nexus theory, different people respond to the same opportunity in different ways depending on their psychological characteristics and past experiences (Eckhardt \& Shane, 2003). One key feature of the theory is that the possession of relevant psychological characteristics alone will not predict opportunity identification, venture formation, or venture success. Rather, it is the interaction of prior knowledge with relevant psychological traits 
(in concert with an appropriate opportunity) that sparks entrepreneurial behavior (Shane, 2000). Moreover, the relevant mix of knowledge and traits might vary across entrepreneurial stages. To date, entrepreneurship research has assumed that "factors that lead to entrepreneurial activity also enhance performance" but this may not be the case (Shane, 2003, p. 265).

This debate is important to budding entrepreneurs and entrepreneurship educators because those without the relevant personality characteristics may be better served by channeling their attention toward non-entrepreneurial careers. On the other hand, the encouragement of those that possess these appropriate attributes to become self-employed and pursue careers in entrepreneurship may benefit both the individual and society. However, nexus theory suggests that entrepreneurial personality traits alone may be insufficient for successful performance. Rather, it is the combination of personality traits and experience that drives success. There may simply be no substitute for relevant industry experience and educators may wish to consider project-based teaching approaches that are action-oriented and encourage experiential learning. This study may also help practicing entrepreneurs to recognize their limitations (either in requisite psychological characteristics or experience) in particular entrepreneurial stages and limit their activities to areas of strength or find other means of assistance. Training might also serve to overcome these limitations.

The purpose of this study is to provide a simple test of nexus theory. Specifically, the interaction between psychological characteristics and prior experience on opportunity exploitation and resource acquisition is explored. The scope of the study is restricted to the resource acquisition aspect of opportunity exploitation, which has been described as "perhaps the most under-researched aspect of the individual and venture creation" (Shook, Priem, \& McGee, 2003, p. 390). It is then argued that the characteristics for successful resource acquisition should vary from the traits associated with other entrepreneurial stages. These issues are explored with the use of an experimental bargaining game that allows a systematic variation of the task experience among participants and directly measures resource acquisition performance.

\section{THEORY AND HYPOTHESES}

This section starts by defining entrepreneurship and the type of entrepreneur under study. It then examines opportunity exploitation in the context of entrepreneurship with a particular focus on the resource acquisition phase. Finally, the role of individual differences in opportunity exploitation is considered, including psychological traits, prior experience, and the nexus of traits and experience.

\section{Definitions}

In line with Austrian/Schumpeterian economics, entrepreneurship is defined as "the recombination of resources in the expectation of profit" (Schumpeter, 1934; Hayek, 1945; Kirzner, 
1973; Casson, 1982; Shane, 2003). These new combinations may include new products, new markets, new processes, or new ways of organizing. However, unlike other views on entrepreneurship, our definition does not necessarily imply the creation of new ventures (see Gartner, 1988). In this view, speculators and corporate venturers are just as 'entrepreneurial' as small business owners and inventors (Vesper, 1980; Casson, 1982).

Entrepreneurial profit arises when the value of the resources in their new use exceeds the value of the resources in their old use (Barney, 1986). Interestingly, there is an assumption that the gains will always flow to the entrepreneur but this is only true if the entrepreneur had complete ex ante control of the relevant resources before the recombination occurred. Otherwise, some of this value may have to be shared with the prior owners of the resources, or strategic factor owners (Barney, 1986). In fact, entrepreneurs rarely have complete control over all of their resources. Some resources, such as human capital, cannot be owned, and as a result, ongoing bargaining with stakeholders is the norm (Coff, 1999). The total value of an entrepreneurial initiative to the entrepreneur is thus the capitalized value of the residual entrepreneurial profits after such bargaining (Lewin \& Phelan, 1999).

It follows that an entrepreneur is one who undertakes entrepreneurship, or the recombination of resources in the expectation of entrepreneurial profit. There is a difference between expected and realized profit because of the inevitable passage of time required to assemble and deploy resources to their new uses. Therefore, entrepreneurs usually bear some risk in their activities. Entrepreneurs tolerate these risks because of their desire for profit. The desire for profit distinguishes our entrepreneur from other types of entrepreneurs, such as Smith's craft entrepreneur or Carland's small business owner who pursues self-employment for personal (i.e. non-profit) motives (Smith, 1967; Carland, Hoy, Boulton, \& Carland, 1984).

\section{Opportunity Exploitation}

While much attention has focused on the discovery and decision to exploit an opportunity (i.e. to start a new venture), less attention has been focused on the actual exploitation phase of the entrepreneurial process (Shane, 2003; Shook et al., 2003). Clearly, a number of steps are required to launch and operate a venture beyond simply making the decision to exploit an opportunity. Shane (2003) lists four steps beyond the decision to exploit: resource acquisition, entrepreneurial strategy, organizing process, and performance. Similarly, Gartner (1985) lists five behaviors: the entrepreneur accumulates resources, the entrepreneur markets products and services, the entrepreneur produces the product, the entrepreneur builds an organization, and the entrepreneur responds to government and society.

In this study, attention is restricted solely to the resource acquisition or resource accumulation stage of opportunity exploitation. There are several reasons for this. First, very few businesses operate without having to acquire additional resources. Second, several classes of 
entrepreneurs, such as traders and speculators, engage exclusively in resource acquisition and disposal and may never build an enduring organization or "product" per se. Their entrepreneurial profits are realized through skilled "resource picking" (Makadok, 2001). Third, in his general theory of entrepreneurship, Shane (2003) treats resource acquisition as if it was primarily about obtaining financial capital. However, the term resource acquisition can also be extended to consider the acquisition of non-financial resources such as plant, property, and equipment as well as all forms of human capital (including knowledge, skills, and other people's social networks). Fourth, as described above, this aspect of entrepreneurship is under-researched and thus represents an important gap in the literature that we seek to begin filling.

Skill at resource-picking is one of two ways to generate wealth without initial endowments or luck (Makadok, 2001). The other way is capability building. Resource picking involves acquiring and using superior resources within established routines (Barney, 1986) whereas capability building involves deploying readily available resources in novel ways (Dierickx \& Cool, 1989). Makadok (2001) argues that these strategies can act as either complements or substitutes for one another at various times. Nevertheless, acquiring superior resources on favorable terms and utilizing them in novel, inimitable ways will tend to create a strong and sustainable competitive advantage.

Central to the concept of resource picking is the notion that the entrepreneur must maintain some sort of information asymmetry with the resource holder that enables them to obtain the resource on favorable terms (Barney, 1986). If the resource holder, or to use Barney's terminology, the strategic factor holder, were to become aware of the future value of the resource they would adjust their price upwards thereby reducing or even eliminating any residual entrepreneurial profits.

\section{Individual Differences in Opportunity Exploitation}

This section considers the effect of individual differences on the resource acquisition stage of opportunity exploitation. It begins with a review of research on personality characteristics and subsequently moves to a discussion of prior experience. The interaction between personality characteristics and experience proposed by nexus theory is considered towards the end of the section.

\section{Personality Characteristics}

A great deal of research over the course of several decades has been dedicated to the study of personality characteristics that predict entrepreneurial behavior. This research generally compares the traits of entrepreneurs with non-entrepreneurs and other professional groups, typically managers (Brockhaus, 1982; Brockhaus \& Horwitz, 1986; Shane, Locke, \& Collins, 2003). The underlying rationale is that entrepreneurs possess traits, dispositions, or motivations that systematically 
discriminate them from these other groups. The descriptions of the personality characteristics utilized in this study are presented in Table 1.

\begin{tabular}{|l|l|}
\hline \multicolumn{1}{|c|}{ Trait } & \multicolumn{1}{c|}{ Table1. Description of personality traits } \\
\hline 1. Need for achievement & $\begin{array}{l}\text { A motivation that leads people to undertake activities and tasks that involve } \\
\text { personal responsibility for outcomes, demand individual effort and skill, involve } \\
\text { moderate risk, and provide clear feedback. }\end{array}$ \\
\hline 2. Risk taking propensity & A person's willingness to engage in risky activities \\
\hline 3. Locus of control & A person's belief that it is possible to influence one's environment \\
\hline 4. Creativity & Identifying, defining, and structuring novel solutions to open-ended problems \\
\hline 5. Social astuteness & $\begin{array}{l}\text { A socially astute person is likely to be an effective negotiator, aware of other's } \\
\text { motives, and diplomatic in presenting issues to others. Such a person will tend to } \\
\text { get his or her way with people without their necessarily becoming aware of the } \\
\text { subtle means used to achieve that purpose. A person high in social astuteness } \\
\text { though may sometimes be considered manipulative or opportunistic, but is more } \\
\text { usually perceived as charming, and a natural leader. }\end{array}$ \\
\hline Sources: Shane (2003), Ciavarella et al (2004), Rubin a Brown (1975)
\end{tabular}

\section{Traditional Traits}

Although entrepreneurial research has examined a wide range of traits, need for achievement, risk-taking propensity, locus of control, and creativity been the most studied characteristics of entrepreneurs (Stewart et al., 1999). Recent meta-analyses have demonstrated that need for achievement and risk-taking propensity distinguish entrepreneurs from the general population (Stewart \& Roth, 2001; Collins et al., 2004). Similar studies have indicated that entrepreneurs possess higher scores on locus of control and creativity than the general population (Shane, 2003). There is an on-going debate on whether founders of small business are distinct from managers (Miner \& Raju, 2004; Stewart \& Roth, 2004) but recent evidence indicates that profit-seeking entrepreneurs possess a higher need for achievement, risk-taking propensity, and creativity than managers (Stewart et al., 1999).

Evidence also suggests that need for achievement and locus of control are important contributors to venture success, as measured by firm survival and sales growth (Shane, 2003; Ciavarella et al., 2004). Similarly, Utsch and Rauch (2000) report that entrepreneurs with higher innovation scores experience higher employment and profit growth. However, Shane (2003) reports that higher risk taking has been negatively associated with firm performance.

There is very little evidence in the entrepreneurship literature on the role of traditional traits in resource acquisition. Ongoing venture performance may be a function of either effective resource 
picking and/or successful capability building so the effects of personality on resource acquisition are confounded with organizing ability. However, indirect evidence of the relationship between traditional traits and resource acquisition may be found in research that examines the effects of these variables on bargaining performance (Rubin \& Brown, 1975; Spector, 1977; L. Greenhalgh, S. A. Neslin, \& R. W. Gilkey, 1985). Bargaining has been defined as "the interaction between individuals over some sale or purchase" (Rubin \& Brown, 1975, p. 2). Resource acquisition is thus arguably a subset of bargaining behavior. Bargaining research indicates that need for achievement, locus of control, and risk-taking are associated with a more competitive style of bargaining, which often ignores interpersonal cues and exploits opponents whenever possible (Rubin \& Brown, 1975).

Extending the research on entrepreneurship and negotiations indicates that each of the traditional variables should have a positive effect on research acquisition performance. For instance, a high need for achievement provides the motivation to achieve superior performance while a high locus of control provides the belief in personal control over the situation. Similarly, a high score on risk-taking represents a willingness to take more risks to achieve higher returns, while innovators will seek out novel approaches to gaining high returns.

Hla: Traditional entrepreneurial traits will be positively associated with resource acquisition performance

\section{Social astuteness}

Several lines of research point to the possibility that entrepreneurs who are adept at interacting with others in face-to-face contexts may gain important benefits and achieve greater financial success (Baron, 2000; Baron \& Markman, 2000; Baron \& Markman, 2003). For example, Phelan (2000) argued that successful entrepreneurs possess an ability to obtain resources on favorable terms by manipulating resource holders' expectations about the future value of resources. Baron and Markman (2000) and Baron (2000) distinguish between social capital (e.g., a favorable reputation, extensive social network etc.) and social competence (an individual's overall effectiveness in interacting with others).

Baron and Markman (2003) suggest that social capital and social competence are both important and that they play distinct but complementary roles in entrepreneurial success. Specifically they argue that whereas social capital helps entrepreneurs gain access to persons important to their success (e.g., venture capitalists), social competence determines the outcomes they experience (e.g., whether they obtain financing or attract customers). They reason that entrepreneurs high in social competence may be more successful in gaining the trust and confidence of persons with whom they interact. As a result, entrepreneurs high in social competence may gain greater access to valuable information and be better able to utilize such knowledge. Consistent with this logic, Baron and Markman (2003) found that social competence was related to financial success for entrepreneurs in both the cosmetics industry and the high-tech industry.

Journal of Entrepreneurship Education, Volume 9, 2006 
This study builds on Baron and Markman's (2003, 2000) and Baron's (2000) research. Based on their logic, individuals high in social competence will be more effective at gaining control over critical resources. Baron and Markman's (2003) research indicates that social competence is positively related to financial performance. However, their study does not explicitly examine whether that relationship is due to the effect of social competence on an entrepreneur's ability to acquire key information or key resources. This study contributes to this line of inquiry by honing in on the importance of social astuteness as a critical component of social competence that influences resource acquisition capability.

Social astuteness is an important political and social skill (Perrewe, Ferris, Frink, \& Anthony, 2000; Ferris, Perrewe, \& Douglas, 2002; Hogan \& Hogan, 2002). Ferris et al. (2002) argue that people high in political skill not only know precisely what to do in different social situations at work, but exactly how to do it in a sincere, engaging manner that disguises any ulterior, self-serving motives. Hogan and Hogan (2002) similarly suggest that people high in sociopolitical intelligence tend to be socially astute and insightful, and they tend to inspire trust and liking from others. Individuals who are high in social astuteness tend to accurately perceive and understand the meaning of social cues and use that information to accomplish a desired goal (Schmit, Kihm, \& Robie, 2000). In the context of entrepreneurship and opportunity exploitation, resource acquisition is a vital goal. Thus, to the extent that opportunity exploitation requires resource acquisition, social astuteness may help individuals accomplish that vital objective. In short, social astuteness is an important social skill that will influence individuals' competence at acquiring key resources.

H1b: $\quad$ Social astuteness will be positively associated with resource acquisition performance.

\section{Prior experience}

Quite a large body of evidence has been assembled on the effects of various life experiences on the decision to exploit an entrepreneurial opportunity. In a wide-ranging review of the literature, Shane (2003) finds positive links between income, unemployment, marital status, education, social networks, and career experience (the latter category including general business experience, functional experience, industry experience, and start up experience). Shane (2003) also presents

evidence of a positive relationship between new venture success (i.e. growth, profitability, and survival) and prior experience, particularly career experience and education.

Prior experience can create "knowledge corridors" that make some opportunities evident to people from certain backgrounds and virtually invisible to those without the right training and experience (Venkataraman, 1997; Shane, 2000). To the extent that we all have different experiences, we will all react to new information in different ways. However, Shane and Khurana (2003) argue that career experience may be one of the most important influences linking individual processes to firm foundings. Similarly, Stuart and Abetti (1990) have presented evidence that 
entrepreneurial experience has a positive effect on early startup performance. In the bargaining literature, Thompson (1990) has demonstrated that experienced bargainers are able to improve their profit performance over naïve bargainers even on unrelated bargaining tasks. Thus, subjects appeared to be learning better strategies for bargaining and not just learning better ways to exploit a given task. These previous observations can also extended to the resource acquisition process, namely:

H2: $\quad$ Subjects with more experience on a resource acquisition task will be more successful than naïve subjects.

\section{Nexus Theory}

According to Shane (2003), a profit-seeking entrepreneur is more likely to exploit an opportunity as the value of that opportunity increases. He further argues that the expected value of an opportunity is influenced by a nexus of three factors: 1) the munificence of the institutional and industry environment, 2) the psychological characteristics of the entrepreneur, and 3) the entrepreneur's non-psychological characteristics, primarily training and career experience. As such, nexus theory is curiously reminiscent of the person-situation debate in psychology (Kenrick \& Funder, 1988) and similar debates in leadership (Fiedler, 1967; Vroom \& Yetton, 1973) and negotiation (Leonard Greenhalgh, Scott A Neslin, \& Roderick W Gilkey, 1985).

In this study, all subjects are presented with the same opportunity. In fact, the payoff for every possible action is fully known to each participant thus the only factors that vary in the design are the subjects' experience and personality. According to nexus theory, relevant experience makes it more likely to identify and exploit an opportunity. However, not all people will be equally motivated. Only those with relevant personality characteristics will choose to exploit the opportunity. This is the nexus or interaction effect between personality and experience.

Moreover, the experience and personality characteristics needed to motivate one to exploit an opportunity might vary from those required to successfully realize the profit opportunity. The characteristics for successful resource acquisition may likewise vary from those required for long term venture success. However, if nexus theory is correct, it follows that:

H3: $\quad$ Experience and relevant entrepreneurial traits will interact to influence resource acquisition performance.

\section{METHOD}

\section{Subjects}

A total of 152 students ( 83 undergraduate and $69 \mathrm{MBA}$ ) participated in the study. Of these, 85 were male, 65 were female, and 2 did not specify gender. The average age of the participants was 
27.8 years (with a range from 20 to 53). There was no significant age difference between the undergraduate and MBA students. The average level of work experience for the entire sample was 6.9 years (with a range from 0 to 33 years) and $10 \%$ of the subject pool reported being selfemployed at some point in their career. Participants were self-assigned to participate in one of eight sessions of around twenty students each. The demographics for each group and overall sample are presented in Table 2. There were no significant differences in demographics between assigned groups.

\begin{tabular}{|l|c|c|c|c|c|c|c|}
\hline \multicolumn{2}{|c|}{ Table 2. Demographics (by group and overall) } \\
\hline \multicolumn{1}{|c|}{ Descriptives } & \multicolumn{2}{c|}{ Mean } & \multicolumn{3}{c|}{ Std Dev } \\
\hline & A & B & All & A & B & All \\
\hline Age & 27.3 & 28.2 & 27.8 & 5.5 & 6.9 & 6.2 \\
\hline Years of Work Experience & 6.3 & 7.4 & 6.8 & 5.4 & 7.0 & 6.2 \\
\hline Foreign Born Parents & 1.4 & 1.3 & 1.4 & 0.9 & 0.9 & 0.9 \\
\hline & & & & & & \\
\hline Frequencies & A & B & All & & & \\
\hline$\%$ Female & $42 \%$ & $44 \%$ & $43 \%$ & & & & \\
\hline$\%$ Self Employed & $24 \%$ & $21 \%$ & $23 \%$ & & & \\
\hline$\%$ Born in US & $75 \%$ & $80 \%$ & $77 \%$ & & & & \\
\hline$\%$ Family Business & $47 \%$ & $37 \%$ & $42 \%$ & & & \\
\hline
\end{tabular}

\section{Design}

Participants were randomly assigned to two groups (A and B) on arrival at the assigned session. Group A participants were assigned to play an exploitation game in one room while Group B played an ultimatum game in another room (see instruments below). After both teams had completed their respective games, they were brought back together and the exploitation game was played again for higher stakes. Both games involved bargaining and negotiation but the exploitation game involved a free-wheeling multiplayer situation and increased uncertainty over outcomes.

\section{Instruments}

Prior to coming to the research session, participants were asked to complete a questionnaire that obtained demographic information and measured the personality traits of interest. 


\section{Personality Traits}

We used the International Personality Item Pool (IPIP) (Goldberg, 1999; International Personality Item Pool, 2001) to assess our personality dimensions. The IPIP places a number of scales in the public domain that correlate highly with the scales on widely used personality inventories usually with higher levels of reliability. Table 3 lists the five personality traits measured in the study, along with the derivative scale, number of items, and Cronbach alphas from our sample.

\begin{tabular}{|c|c|c|c|}
\hline Personality Trait (IPIP) & Based on & Items & $\begin{array}{c}\text { Sample } \\
\text { Alpha }\end{array}$ \\
\hline Need for achievement & Six Factor Personality Questionnaire: Achievement & 10 & 0.88 \\
\hline Risk-taking propensity & Jackson Personality Inventory: Risk-taking & 10 & 0.87 \\
\hline Locus of control & Personal Attributes Survey: Total Locus of Control & 20 & 0.90 \\
\hline Creativity & Jackson Personality Inventory: Innovation & 10 & 0.91 \\
\hline Social astuteness & Jackson Personality Inventory: Social Astuteness & 6 & 0.81 \\
\hline
\end{tabular}

\section{Behavioral measures}

We used two behavioral instruments to assess the likelihood of subjects commencing a new business in order to further validate our results. The entrepreneurial quotient (EQ) questionnaire was selected as the most effective discriminator between entrepreneurs, owner-managers, and nonentrepreneurs in the extant literature (Huefner, Hunt, \& Robinson, 1996). We also utilized a fouritem scale adapted from Singh and DeNoble (2003) that assessed participants' attitudes toward entrepreneurship and their desire to become entrepreneurs Sample items for this scale included, "I intend to become self employed" and "I have the ability to recognize ideas for self employment." Cronbach's alpha for this scale was .88 .

\section{Games}

The exploitation game that was utilized is a variation of the ten dollar game by Christie and Geis (1970), The game combines elements of integrative and distributive bargaining in a multiplayer setting and has a readily determined Pareto optimal solution (see Appendix 1 for detailed instructions).

In the exploitation game, subjects are given one poker chip that they are told will be worth $\mathrm{x}$ at the end of the game ( $\mathrm{x}$ was $\$ 0.10$ in the first round and $\$ 0.50$ in the second). However, any 
player that can accumulate ten chips by the end of the game receives a payoff of $2 x$ per chips or 20x in total. Players accumulate chips by making side-payments (or agreements) with other players.

What makes the game interesting is that the payoff per chip is not constant, rising linearly between 1 and 10 chips. So, for instance, having five chips at the end of the game will only result in $1.5 x$ per chip. Players are thus uncertain about the total payoff that they might receive at the end of the game. A Pareto optimum occurs when no player can be made better off without making some other player worse off. A Pareto optimum occurs when the participants are maximizing the net benefits of the game. In this case, the Pareto optimum for the game is 2x (or $\$ 1$ in the second exploitation game). One way this could occur is for one player to accumulate ten chips (for a total payoff of 20x) by making side payments of $2 x$ to nine other players so that all players receive a net profit of $2 x$ or exactly double their starting, or 'do nothing', positions.

Half of the subjects also played a basic ultimatum game. In an ultimatum game (Guth, Schmittberger, \& Schwartz, 1982), one player, the initiator, makes an offer to split a fixed amount of money with another, the recipient. The recipient can either accept the proposed split, in which case both parties keep the money in the proposed proportions, or the recipient can reject the split, in which case both parties receive nothing. In our case, the amount to be split was ten pennies. The Nash equilibrium for this game is a 9:1 split in favor of the initiator but many studies have demonstrated that subjects tend to make an even split (Roth, 1995).

\section{Dependent variables}

Two aspects of performance on the second entrepreneurial game formed the dependent variables for this study. First, we asked participants to estimate how much profit they expected to make in the second exploitation game. Our second dimension of performance was the participants' actual net profit in the second game (net profit = payout based on the number of chips held minus purchases of chips from other players plus sales of chips to other players).

\section{PROCEDURE}

On reporting to their assigned session, participants were randomly separated into two groups (A and B). Participants in the first group (A) remained in the original room with one experimenter and played the exploitation game. After receiving the exploitation game instructions and before actually playing the game, participants were asked to respond to a series of questions that assessed their understanding of the instructions, their motivation for doing well at the game, and their expected level of performance. Participants then played the game for 15 minutes.

Participants in the second group (B) went with the other experimenter to another room where they participated in three rounds of the ultimatum game. The first two games were for practice with 
subjects taking turns as the initiator and receiver of the initial ultimatum. In the third and final game, subjects were able to retain their earnings.

After the ultimatum game and first exploitation game, participants were reunited and the entire group played the second exploitation game. The participants from Group A heard the instructions again while the participants from Group B received the instructions for the first time. As before, all participants were asked to indicate the extent to which they understood the instructions, their motivation for doing well at the game, and their expected level of performance. Participants then played the game for 15 minutes. Following the session, participants with chips were compensated based on the number of chips they possessed. All players then paid their debts and received their credits from the other players. At the completion of this stage of the experiment, individuals were thanked again for their involvement in the study and debriefed concerning the purpose of the study. The entire set of games took about one hour per session.

\section{RESULTS}

The descriptive statistics by treatment group (A and B) and correlations among the variables in the study are presented in Table 4 . The means for both groups are well above the mid points on all scales consistent with earlier findings that business students differ from the general population on many of these variables. Two tailed t-tests revealed no significant differences between the group means on any of the personality variables or expected profit at the 0.05 level.

In general, the subjects did well on the second bargaining task, earning an average of $89.7 \%$ of the available cash in each session (in a range from $81 \%$ to $100 \%$ ). This was an improvement from $82.9 \%$ in the first run of the exploitation game. Only five subjects (or $3 \%$ ) earned the minimum of $\$ 0.50$ for their chip by making no trades. However, overall, the profits of those holding chips at the end of the game were significantly higher than those that did not hold chips $(\mathrm{t}=2.82, \mathrm{p}<0.01)$. This indicates that those acquiring chips did better than those selling chips.

\begin{tabular}{|l|c|c|c|c|c|c|c|c|c|c|c|}
\hline \multicolumn{10}{|c|}{ Table 4. Descriptives and correlations } \\
\hline Variable & Mean A & Mean B & 1 & 2 & 3 & 4 & 5 & 6 & 7 & 8 & 9 \\
\hline 1. Need for achievement & 41.88 & 41.14 & 1.00 & & & & & & & & \\
\hline 2. Risk-taking propensity & 29.68 & 27.99 & 0.09 & 1.00 & & & & & & & \\
\hline 3. Locus of control & 82.00 & 80.62 & 0.55 & 0.15 & 1.00 & & & & & & \\
\hline 4. Creativity & 38.14 & 37.89 & 0.26 & 0.38 & 0.41 & 1.00 & & & & & \\
\hline 5. Social astuteness & 20.60 & 19.31 & 0.10 & 0.46 & 0.29 & 0.56 & 1.00 & & & & \\
\hline 6. Entrepreneurial quotient & 10.06 & 6.24 & 0.27 & 0.52 & 0.32 & 0.54 & 0.41 & 1.00 & & & \\
\hline 7. Entrepreneurial intentions & 22.61 & 19.38 & 0.23 & 0.35 & 0.30 & 0.50 & 0.32 & 0.69 & 1.00 & & \\
\hline 8. Expected profit & 1.71 & 1.63 & 0.08 & 0.16 & 0.12 & 0.25 & 0.16 & 0.11 & 0.25 & 1.00 & \\
\hline 9. Actual profit & 1.01 & 0.80 & 0.06 & 0.10 & 0.13 & 0.25 & 0.22 & 0.16 & 0.13 & 0.18 & 1.00 \\
\hline
\end{tabular}


We utilized a series of regression models to test the experimental design. Each model took the form, profit $=f$ (variable, group, variable $\mathrm{x}$ group). The results of these analyses are presented in Table 4. Our first set of hypotheses predicted that the possession of relevant entrepreneurial traits would enhance resource acquisition performance. Innovativeness was the only variable to show a significant main effect on expected profit without a significant interaction term. Thus, hypotheses $1 \mathrm{a}$ and $1 \mathrm{~b}$ received little support.

\begin{tabular}{|c|c|c|c|c|c|c|}
\hline \multirow[t]{2}{*}{ Dependent variable } & \multicolumn{3}{|c|}{ Expected Profit } & \multicolumn{3}{|c|}{ Actual Profit } \\
\hline & $F$ ratio & t ratio & t ratio & F ratio & $\mathrm{t}$ ratio & t ratio \\
\hline Independent variables & $\begin{array}{l}\text { whole } \\
\text { model }\end{array}$ & $\begin{array}{l}\text { main } \\
\text { effect }\end{array}$ & $\begin{array}{l}\text { interaction } \\
\text { with group }\end{array}$ & $\begin{array}{l}\text { whole } \\
\text { model }\end{array}$ & $\begin{array}{l}\text { main } \\
\text { effect }\end{array}$ & $\begin{array}{l}\text { interaction } \\
\text { with group }\end{array}$ \\
\hline Group & 0.07 & 0.27 & n.a. & $5.10^{*}$ & $2.26^{*}$ & n.a. \\
\hline Need for achievement & 0.96 & 0.77 & 1.36 & 2.46 & 0.23 & 1.85 \\
\hline Risk-taking propensity & $2.65^{*}$ & $2.14^{*}$ & $2.03 *$ & $4.39 * *$ & 1.26 & $2.60 * *$ \\
\hline ocus of control & 0.99 & 0.19 & 0.87 & $6.08 * * *$ & 0.89 & $3.30 * * *$ \\
\hline Creativity & $3.54^{*}$ & $2.79 * *$ & 1.16 & $7.81 * * *$ & $7.14 * *$ & $7.91 * *$ \\
\hline Social astuteness & 2.15 & 1.66 & 1.57 & $6.01 * * *$ & 1.76 & $2.71 * * *$ \\
\hline
\end{tabular}

Our second hypothesis predicted that participants with experience on the resource acquisition task would outperform participants without experience. As shown in table 5, the results support this hypothesis. There is a significant main effect for group on actual profits but not expected profit. This seems to provide some support for the second hypothesis, but the result must be considered in light of the observed interactions with the other independent variables.

Finally, our third hypothesis predicted that psychological traits and experience would interact. The results strongly support this hypothesis, albeit not with all variables. As seen in Table 5 , the interaction significantly predicts actual profits for four of the five variables. The nature of the interaction can be clearly seen in the interaction plot of social astuteness and actual profit presented in Figure 1, which is indicative of all the significant relationships. The figure reveals no significant difference between the performances of those with low social astuteness in either group, and indeed those with high astuteness and low experience do not seem to do much better. The standout group is the one with high social astuteness and high task experience. However, the interaction pattern was virtually absent in the models of expected profit with only risk-taking showing a significant interaction effect. 
Figure 1. Interaction of experience and social astuteness

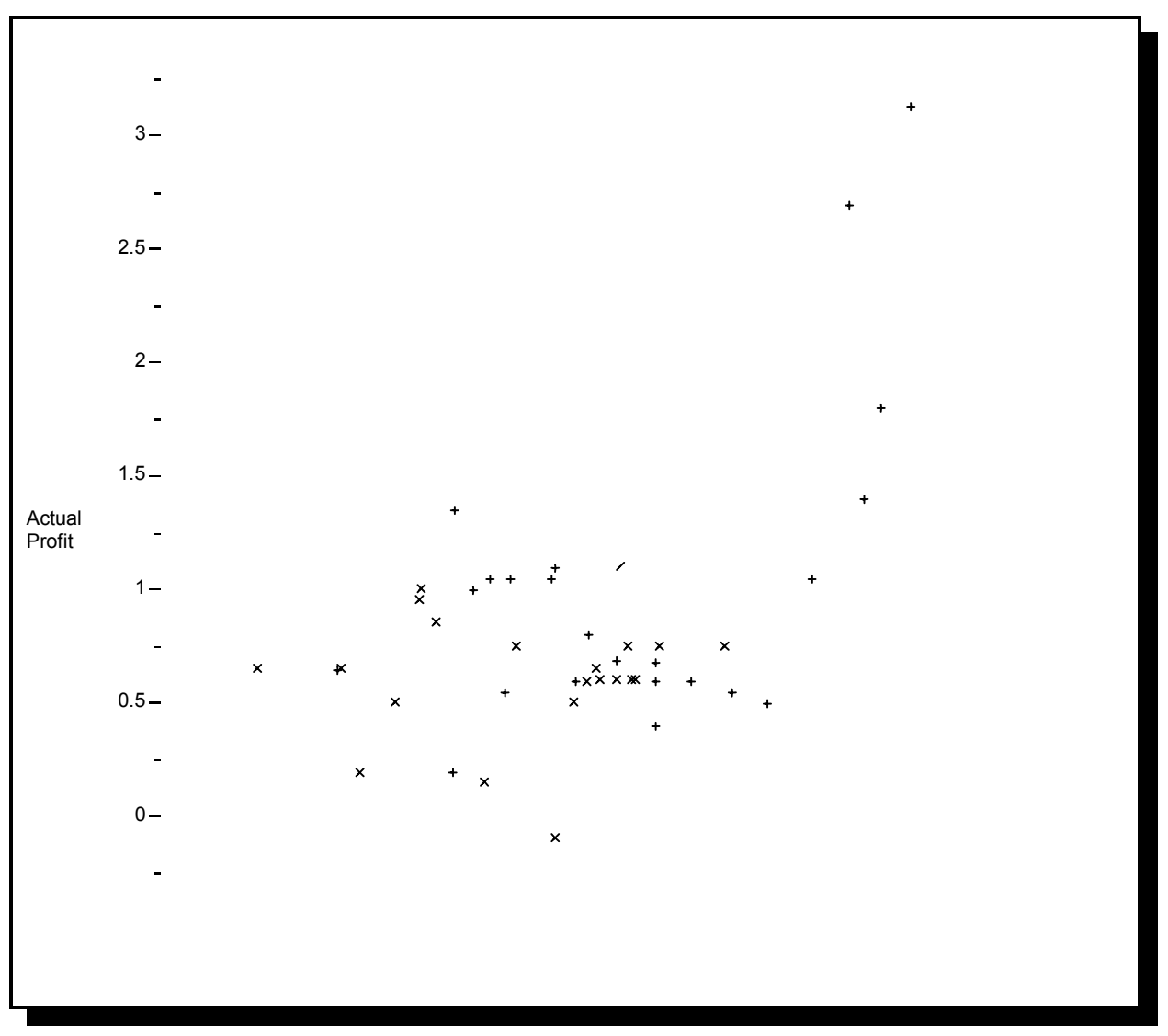

DISCUSSION

These results provide support for one of the key predictions of nexus theory, namely that an interaction effect should exist between experience and personality characteristics. It was discovered that subjects with higher risk-taking propensity and creativity expected more profits, but that they only succeeded in generating higher profits if they had prior experience on the bargaining task. However, experience per se did not lead to higher profits unless a player also possessed relevant psychological characteristics. These characteristics included traditional entrepreneurial traits, such as risk-taking propensity, creativity, and locus of control.

The study also indicates that social astuteness is an important trait in resource acquisition. This finding supports Phelan's (2000) argument that entrepreneurs need to be particularly good at resource picking to overcome the inherent liabilities of smallness and newness common to most entrepreneurial ventures. This result is also consistent with Baron and Markman's (2003) argument that entrepreneurs who are adept at interacting in social contexts may achieve greater success. 
Finally, the pattern of significance varied between the two dependent variables. Social astuteness and locus of control were important for realizing actual profits but did not predict expected profits, whereas risk-taking and creativity played a more important role in driving profit expectations. These findings are in line with Shane's (2003) prediction that relevant entrepreneurial characteristics would likely vary across different stages in the venture creation process.

\section{IMPLICATIONS}

These findings have a number of implications for entrepreneurship researchers. First, the experience by personality interaction obtained in this study provides an explanation for the mixed results obtained in prior trait research in entrepreneurship. Namely, unless trait research controls for experience, the interaction effect will produce inconsistent findings between samples. In addition, the study also controlled for the quality of the entrepreneurial opportunity by presenting all participants with the same opportunity. Nexus theory would predict that variations in the quality of the opportunity between entrepreneurs could also contaminate results. Thus, future research that seeks to isolate the effects of entrepreneurial characteristics should seek to control for extraneous factors such as prior experience and the quality of the opportunity. At a minimum, these factors should be considered in future research.

The relevant entrepreneurial traits also appear to vary by development stage. More interactions were present in the resource acquisition stage (where actual profits could be made) than the opportunity identification stage (where expectations about profit were formed). Of course, the task description itself provided a lot of information about potential profits so the role of experience in opportunity identification may have been attenuated by the task itself. In the past, researchers have sought a single "entrepreneurial personality" type. The evidence in this study suggests that some attributes may be more important at different stages. It may be possible for entrepreneurs to compensate for missing talents by forming alliances or building relationships at different stages to acquire the talents they lack. This may explain observed alliances patterns and venture growth.

These results also have several practical implications. First, the study suggests that would-be entrepreneurs should realize that possessing the entrepreneurial characteristics required to start a new business may not be sufficient for new venture success. Relevant experience also plays a major role in performance and may explain the venture capitalist community's focus on experience as a primary determinant in funding decisions (Stuart \& Abetti, 1990). Entrepreneurial education will thus likely be more effective when schools form partnerships with businesses that enable students to benefit from both course-based action learning and actual industry experience. The study also reveals that specific traits such as self-efficacy (locus of control), social astuteness, risk-taking propensity, and creativity are important for assembling the resources required to exploit an opportunity. Entrepreneurial education that attempts to consciously develop these particular traits should therefore enhance the likelihood of entrepreneurial success. 
The study also opens up a number of avenues for future research. For instance, entrepreneurs in ventures that emphasize resource-picking (such as traders and speculators) would likely score higher on social astuteness than enterprise builders. It may also be the case that profit-oriented entrepreneurs, in general, score higher on social astuteness than small business owners or managers. From a methodological standpoint, it would be interesting to explore whether the results are consistent across different resource-picking tasks, both in the laboratory and in more naturalistic settings. The design of the current study captures some important elements of the real world challenge facing entrepreneurs seeking to exploit an opportunity. However, other methods for studying the resource acquisition process could also be explored.

\section{LIMITATIONS}

As with all research, this study has some limitations. The use of a laboratory simulation raises concerns about external validity. However, at this stage, it was considered more important to strive for internal validity because nexus theory is relatively new and the interactive effects of experience and personal characteristics on resource acquisition are not yet well understood in the entrepreneurship literature. The objective was to provide an initial test of one component of the nexus theory. Specifically, the aim was to see if the interaction between personality characteristics and experience proposed by nexus theory was supported. Accomplishing this objective required that the quality of opportunity and level of task experience were strictly controlled. A laboratory study proved to be an ideal environment for this type of work.

Still, the concerns about generalizability warrant attention. Several aspects of the study reduce some of these concerns. First, the task employed in this study required participants to acquire tangible resources (chips) that directly led to individual performance and profitability. Huefner and Hunt (1994) argue that entrepreneurship can occur in non-business settings and that entrepreneurs may engage in activities other than founding a business. They define entrepreneurship as recognizing an opportunity and marshalling the resources to take advantage of or act on that opportunity. The paper defines entrepreneurship as the recombination of resources in the expectation of profit. Thus, by definition, the game may be considered an entrepreneurial task and the subjects micro-entrepreneurs.

A second potential threat to external validity centers on the appropriateness of student participants. In fact, a number of participants had actually started their own business in the past. Post hoc analyses revealed that those participants who had previously started their own business did better on this task suggesting that it might have external validity. The appropriateness of the sample was further assessed by using the Entrepreneurial Quotient (EQ) tool and by measuring participants' intentions to start a business. Prior research demonstrates that the EQ effectively differentiates entrepreneurs from non-entrepreneurs. As a result, participants who scored high on the EQ and expressed high entrepreneurial intent will be more likely to start businesses in the future. The results

Journal of Entrepreneurship Education, Volume 9, 2006 
further indicated that participants who obtained high scores on the EQ and who indicated high entrepreneurial intentions also performed well on the entrepreneurial exploitation game, further reinforcing its validity.

In sum, the study provides a tightly controlled first test of the interaction predicted by nexus theory while simultaneously addressing external validity concerns. However, the degree to which these findings extend to entrepreneurial situations with higher stakes and greater complexity (e.g., multiple sources of financing and resources, numerous stakeholders etc.) remains uncertain. In the field, opportunity exploitation requires the acquisition of resources that involve significantly greater expense and risk and considerably higher potential returns. Based on nexus theory, we expect that the relationship observed in this study would also prevail in entrepreneurial situations with greater stakes. Nevertheless, future research should seek to replicate these findings in the field.

\section{CONCLUSION}

The results of this study indicate that personality characteristics and relevant experience worked together to determine participants' profits. Thus, potential entrepreneurs who possess both the relevant personality characteristics and experience may be expected to be more adept at resource acquisition and opportunity exploitation than entrepreneurs who lack either experience or critical personality traits. In addition to traditional variables, such as risk-taking and creativity, this study identifies social astuteness as a personality trait that enhances individuals' resource acquisition competence. However, interaction effects were not evident when making profit projections. This suggests that the relative importance of personality traits may vary at different stages of the entrepreneurial process. In combination, the study presented in this paper serves as an important first test of nexus theory and provides initial empirical support for the theory. Additional research along these lines will further enhance both entrepreneurship practice and research.

\section{REFERENCES}

Barney, J. B. (1986). Strategic factor markets, expectations, luck and business strategy. Management Science, 32(10), 1231-1241.

Baron, R. A. (2000). Psychological perspectives on entrepreneurship: Cognitive and social factors in entrepreneurs' success. Current Directions in Psychological Science, 15-18.

Baron, R. A., \& Markman, G. D. (2000). Beyond social capital: How social skills can enhance entrepreneurs' success. Academy of Management Executive, 14(1), 106-116.

Baron, R. A., \& Markman, G. D. (2003). Beyond social capital: The role of entrepreneurs' social competence in their financial success. Journal of Business Venturing, 18(1), 41-60. 
Brockhaus, R. H. (1982). The psychology of the entrepreneur. In C. A. Kent \& D. L. Sexton \& K. H. Vesper (Eds.), Encyclopedia of entrepreneurship (pp. 39-57). Englewood Cliffs, NJ: Prentice-Hall.

Brockhaus, R. H., \& Horwitz, P. S. (1986). The psychology of the entrepreneur. In D. L. Sexton \& R. W. Smilor (Eds.), The art and science of entrepreneurship. Cambridge, MA: Ballinger.

Busenitz, L. W., \& Barney, J. B. (1997). Differences between entrepreneurs and managers in large organizations: Biases and heuristics in strategic decision making. Journal of Business Venturing, 12(1), 9-30.

Carland, J. W., Hoy, F., Boulton, W. R., \& Carland, J. C. (1984). Differentiating entrepreneurs from small business owners: A conceptualization. Academy of Management Review, 9(2), 354-359.

Casson, M. (1982). The entrepreneur: An economic theory. Oxford: Martin Robertson.

Christie, R., \& Geis, F. L. (1970). Studies in machiavellianism. New York: Academic Press.

Ciavarella, M. A., Buchholtz, A. K., Riordan, C. M., Gatewood, R. D., \& Stokes, G. S. (2004). The big five and venture survival: Is there a linkage? Journal of Business Venturing, 19(4), 465-483.

Coff, R. W. (1999). When competitive advantage doesn't lead to performance: The resource-based view and stakeholder bargaining power. Organization Science, 10(2), 119-133.

Collins, C., Hanges, P., \& Locke, E. (2004). The relationship of achievement motivation to entrepreneurial behavior: A meta-analysis. Human Performance, 17(1), 95-117.

Dierickx, I., \& Cool, K. (1989). Asset stock accumulation and sustainability of competitive advantage. Management Science, 35(12), 1504-1511.

Eckhardt, J. T., \& Shane, S. A. (2003). Opportunities and entrepreneurship. Journal of Management, 29(3), 333-349.

Ferris, G. R., Perrewe, P. L., \& Douglas, C. (2002). Social effectiveness in organizations: Construct validity and research directions. Journal of Leadership and Organizational Studies, 9, 49-63.

Fiedler, F. (1967). A contingency theory of leadership effectiveness. New York, NY: McGraw-Hill.

Gartner, W. B. (1985). A conceptual framework for describing the phenomenon of new venture creation. Academy of Management Review, 10(4), 696-706.

Gartner, W. B. (1988). "who is an entrepreneur?" is the wrong question. Entrepreneurship Theory \& Practice, 5, 47-68.

Goldberg, L. R. (1999). A broad-bandwidth, public domain, personality inventory measuring the lower-level facets of several five-factor models. In I. Mervielde \& I. Deary \& F. D. Fruyt \& F. Ostendorf (Eds.), Personality psychology in europe (Vol. 7, pp. 7-28). Tilburg: Tilburg University Press.

Greenhalgh, L., Neslin, S. A., \& Gilkey, R. W. (1985). The effects of negotiator preferences, situational power, and negotiator personality on outcomes of business negotiations. Academy of Management Journal, 28(1), 9-33.

Journal of Entrepreneurship Education, Volume 9, 2006 
Guth, W., Schmittberger, R., \& Schwartz, B. (1982). An experimental analysis of ultimatum bargaining. Journal of Games and Economic Behavior, 3, 367-388.

Hayek, F. A. (1945). The use of knowledge in society. American Economic Review, 35, 519-530.

Hogan, J., \& Hogan, R. (2002). Leadership and sociopolitical intelligence. In R. E. Riggio \& E. E. Murphy \& F. J. Pirozzola (Eds.), Multiple intelligences and leadership (pp. 75-88). Mahwah, NJ: Lawrence Erlbaum.

Huefner, J. C., Hunt, H. K., \& Robinson, P. B. (1996). A comparison of four scales predicting entrepreneurship. Academy of Entrepreneurship Journal, 1(2), 56-80.

International Personality Item Pool. (2001). A scientific collaboratory for the development of advanced measures of personality traits and other individual differences. http://ipip.ori.org. Retrieved, from the World Wide Web:

Kenrick, D. T., \& Funder, D. C. (1988). Profiting from controversy: Lessons from the person-situation debate. American Psychologist, 43(1), 23-34.

Kirzner, I. (1973). Competition and entrepreneurship. Chicago, IL: University of Chicago Press.

Lewin, P., \& Phelan, S. E. (1999). Firms, strategies and resources: Contributions from austrian economics. Quarterly Journal of Austrian Economics, 2(2), 3-18.

Low, M. B., \& MacMillan, I. C. (1988). Entrepreneurship: Past research and future challenges. Journal of Management, 14(2), 139-161.

Makadok, R. (2001). Toward a synthesis of the resource-based and dynamic-capability views of rent creation. Strategic Management Journal, 22(5), 387-401.

Miner, J. B., \& Raju, N. S. (2004). Risk propensity differences between managers and entrepreneurs and between lowand high-growth entrepreneurs: A reply in a more conservative vein. Journal of Applied Psychology, 89, 3-13.

Perrewe, P. L., Ferris, G. R., Frink, D. D., \& Anthony, W. P. (2000). Political skill: An antidote for workplace stress. Academy of Management Executive, 14, 115-123.

Phelan, S. E. (2000). Entrepreneurship as expectations management. Paper presented at the Annual Meeting of the Academy of Management, Washington DC.

Roth, A. E. (1995). Bargaining experiments. In J. H. Kagel \& A. E. Roth (Eds.), The handbook of experimental economics. Princeton, NJ: Princeton University Press.

Rubin, J. Z., \& Brown, B. R. (1975). The social psychology of bargaining and negotiation. New York: Academic Press.

Schumpeter, J. A. (1934). The theory of economic development (R. Opie, Trans.). Cambridge, MA: Harvard University Press. 
Shane, S. (2000). Prior knowledge and the discovery of entrepreneurial opportunities. Organization Science, 11(4), 448469.

Shane, S. (2003). A general theory of entrepreneurship: The individual-opportunity nexus. Cheltenham, UK: Edward Elgar.

Shane, S., \& Khurana, R. (2003). Bringing individuals back in: The effects of career experience on new firm founding. Industrial \& Corporate Change, 12(3), 519-543.

Shane, S., Locke, E. A., \& Collins, C. J. (2003). Entrepreneurial motivation. Human Resource Management Review, 13(2), 257-279.

Shane, S., \& Venkataraman, S. (2000). The promise of entrepreneurship as a field of research. Academy of Management Review, 26(1), 13-17.

Shook, C. L., Priem, R. L., \& McGee, J. E. (2003). Venture creation and the enterprising individual: A review and synthesis. Journal of Management, 29(3), 379-399.

Singh, G., \& DeNoble, A. (2003). Views on self-employment and personality: An exploratory study. Journal of Developmental Entrepreneurship, 8(3), 265-281.

Smith, N. R. (1967). The entrepreneur and his firm. East Lansing, MI: Michigan State University Press.

Spector, B. I. (1977). Negotiation as a psychological process. Journal of Conflict Resolution, 21(4), 607-618.

Stewart, W. H., \& Roth, P. L. (2001). Risk propensity differences between entrepreneurs and managers: A meta-analytic review. Journal of Applied Psychology, 86(1), 145-153.

Stewart, W. H., \& Roth, P. L. (2004). Data quality affects meta-analytic conclusions: A response to miner and raju (2004) concerning entrepreneurial risk propensity. Journal of Applied Psychology, 89(1), 14-21.

Stewart, W. H., Watson, W. E., Carland, J. C., \& Carland, J. W. (1999). A proclivity for entrepreneurship: A comparison of entrepreneurs, small business owners, and corporate managers. Journal of Business Venturing, 14(2), 189-214.

Stuart, R. W., \& Abetti, P. A. (1990). Impact of entrepreneurial and management experience on early performance. Journal of Business Venturing, 5(3), 151-162.

Thompson, L. (1990). An examination of naive and experienced negotiators. Journal of Personality and Social Psychology, 59(1), 82-90.

Utsch, A., \& Rauch, A. (2000). Innovativeness and initiative as mediators between achievement orientation and venture performance. Journal of Work and Organizational Psychology, 9(1), 45-62.

Journal of Entrepreneurship Education, Volume 9, 2006 
Venkataraman, S. (1997). The distinctive domain of entrepreneurship research: An editor's perspective. In J. Katz \& R. Brockhaus (Eds.), Advances in entrepreneurship, firm emergence, and growth (Vol. 3, pp. 119-138). Greenwich, CT: JAI Press.

Vesper, K. H. (1980). New venture strategies. Englewood Cliffs, NJ: Prentice Hall.

Vroom, V. H., \& Yetton, P. W. (1973). Leadership and decision-making. Pittsburgh, PA: University of Pittsburgh Press.

\section{Appendix 1. Exploitation Game Instructions}

Name:

Student \#:

Class:

You have been given one poker chip. You have 15 minutes to make the most of that chip. You have two main options. First, you may simply hold on to your chip and do nothing. Second, you may buy and sell chips from other players in an effort to maximize your profit. The more chips you have at the end of the game, the more money you will be rewarded for each chip.

The amount of money you receive at the end of the game will be based on the number of chips you have based on the payout chart on the reverse side of this page.

Your net profit is the amount of money you receive from the game administrator plus the sum of sales you made to other players minus the sum of purchases you made from other players. The winner is the individual who has the highest profit at the end of the game.

Example: You hold your chip and do nothing. At the end of the game you will receive a total payoff of $\$ 0.10$ in exchange for that chip. Your net profit is also $\$ 0.10$.

Example: You purchase one chip from another player for $\$ 0.10$ and have a total of two chips at the end of the game. You will be given $\$ 0.12$ per chip for a total payoff of $\$ 0.24$. Your net profit is $\$ 0.14$ : your $\$ 0.24$ payoff minus your total purchases of $\$ 0.10$.

Example: You purchase one chip from another player for $\$ 0.10$ and later sell both chips for $\$ 0.15$ each ( $\$ 0.30$ total). You have no chips to trade in at the end of the game. Your net profit is $\$ 0.20$ : your total sales of $\$ 0.30$ less purchases of $\$ 0.10$. Note: The maximum number of chips an individual may hold is 10 (as a result the maximum payout for anyone is $\$ 2.00$ ).

Throughout the game you must strictly follow two rules:

1. You may only talk to one person at a time.

Note: Although you may talk to only one person at a time, throughout the game you may make as many deals with as many different players as you like. You may also trade with the same player as many times as you would like. You are also not limited as to the number of chips you may sell or purchase in any one deal.

2. Each agreement you make during the session must be completely recorded on the transaction sheet on the reverse side of this page. Both the buyer and the seller should record the transaction on their own sheet and sign the other person's transaction sheet.

Example: If you sell two chips to another player for a total of \$2.00, you should put a 2 in the number of chips column, $\$ 2.00$ in the total sales price column and have them initial the last column. The person you sold them to should put a 2 in the number of chips column, \$2.00 in the total sales price column and have you initial the last column.

Please turn this paper over and answer the 5 questions at the top of the page 


\section{SCORE SHEET}

\section{Expectations}

1. On a scale from $1-10$, how well do you understand the instructions and how to play the game? $(1=$ not at all; $10=$ completely understand).

2. On a scale from 1-10, how motivated are you to do well in this game? $(1=$ not at all; $10=$ extremely motivated $)$.

3. How much profit do you expect to make in this game? $\$$

4. How many chips do you expect to have at the end of the game? chips

5. How many transactions do you expect to make during the game? transactions

Transaction Record:

\begin{tabular}{|l|l|l|l|}
\hline \multicolumn{2}{|c|}{ Transaction Record } & Total Purchase Price & Initials \\
\hline & Total Sales Price & & \\
\hline & & & \\
\hline & & & \\
\hline & & & \\
\hline & & & \\
\hline Totals & & & $\$$ \\
\hline
\end{tabular}

\section{Payoff Schedule}

\begin{tabular}{|l|c|c|c|c|c|c|c|c|c|c|c|}
\hline \multicolumn{10}{|c|}{ Payoff Schedule } \\
\hline Chips & 0 & 1 & 2 & 3 & 4 & 5 & 6 & 7 & 8 & 9 & 10 \\
\hline $\begin{array}{l}\text { Payment } \\
\text { per chip }\end{array}$ & $\$ 0$ & $\$ x$ & $\$ 1.2 x$ & $\$ 1.3 x$ & $\$ 1.4 x$ & $\$ 1.5 x$ & $\$ 1.6 x$ & $\$ 1.7 x$ & $\$ 1.8 x$ & $\$ 1.9 x$ & $\$ 2 x$ \\
\hline $\begin{array}{l}\text { Total } \\
\text { Payoff }\end{array}$ & 0 & $\$ x$ & $\$ 2.4 x$ & $\$ 3.9 x$ & $\$ 5.6 x$ & $\$ 7.5 x$ & $\$ 9.6 x$ & $\$ 11.9 x$ & $\$ 14.4 x$ & $\$ 17.1 x$ & $\$ 20.0 x$ \\
\hline
\end{tabular}

Note: $x=\$ 0.10$ in the first game and $x=\$ 0.50$ in the second game

NET PROFIT $=$ TOTAL PAYOFF + Total Sales - Total Purchases $\$$ 


\section{Allied Academies \\ invites you to check our website at \\ www.alliedacademies.org \\ for information concerning}

conferences and submission instructions 


\section{Allied Academies \\ invites you to check our website at www.alliedacademies.org \\ for information concerning}

conferences and submission instructions 